\title{
7. SITE 358: ARGENTINE BASIN
}

\author{
The Shipboard Scientific Party ${ }^{1}$
}

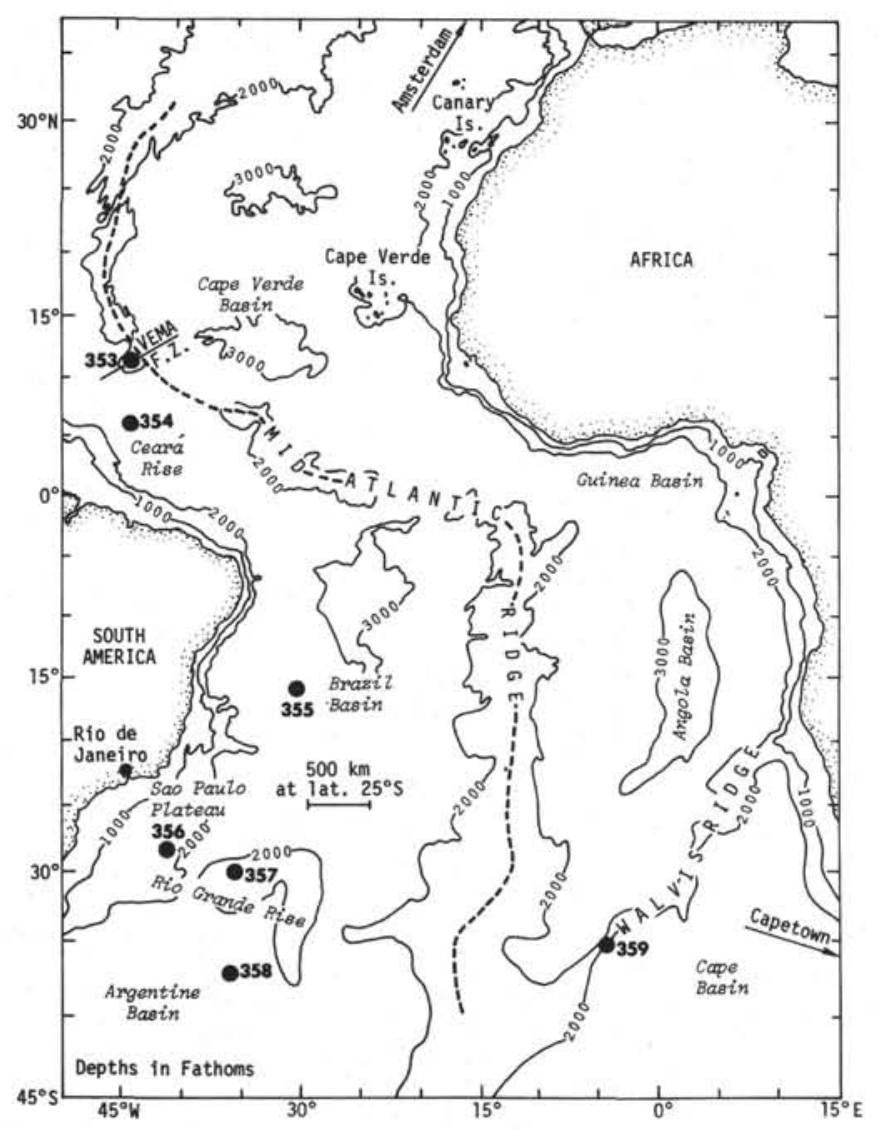

\section{SITE DATA}

Date Occupied: 30 November 1974 (0701Z).

Date Departed: 3 December 1974 (2012Z)

Time on Site: 3 days, 13 hours

Position: $37^{\circ} 39.31^{\prime} \mathrm{S}, 35^{\circ} 57.82^{\prime} \mathrm{W}$

Accepted Water Depth: 4990 meters (drill pipe measurement)

Penetration: 842 meters

'K. Perch-Nielsen, Eidg. Technische Hochschule, Zürich, Switzerland (Co-chief scientist); P.R. Supko, Scripps Institution of Oceanography, La Jolla, California (Co-chief scientist); A. Boersma, Lamont-Doherty Geological Observatory, Palisades, New York; R.L. Carlson, University of Washington, Seattle, Washington; M.G. Dinkelman, The Florida State University, Tallahassee, Florida; R.V. Fodor, University of New Mexico, Albuquerque, New Mexico; N. Kumar, Lamont-Doherty Geological Observatory, Palisades, New York; F. McCoy, Lamont-Doherty Geological Observatory, Palisades, New York; J. Thiede, Oregon State University, Corvallis, Oregon: H.B. Zimmerman, Union College, Schenectady, New York.

\section{Number of Holes: 1}

Number of Cores: 16

Total Length of Cored Sections: 152.0 meters

Total Core Recovered: 89.3 meters

Principal Results: We drilled and cored at Site 358 in the northeastern Argentine Basin to a total depth of 842 meters subbottom. Two major lithologic units occur. The first extends from the sediment surface to 730 meters, and comprises siliceous mud and mudstone, of mid-Eocene to probably Holocene age. Terrigenous mudstone and marly chalk of Late Cretaceous to middle Eocene age underlie these sediments.

The top of Horizon A (Ewing and Lonardi, 1971) correlates well with the contact between diatom-radiolarian mudstone and siliceous mudstone at 460 meters; at this specific site, it is thus a diagenetic horizon of late Oligocene age. The top of Horizon B correlates very well with the contact of noncalcareous mudstone to middle Eocene marly chalk at 730 meters. Basement was calculated to lie at 897 meters. Very bad weather condi-

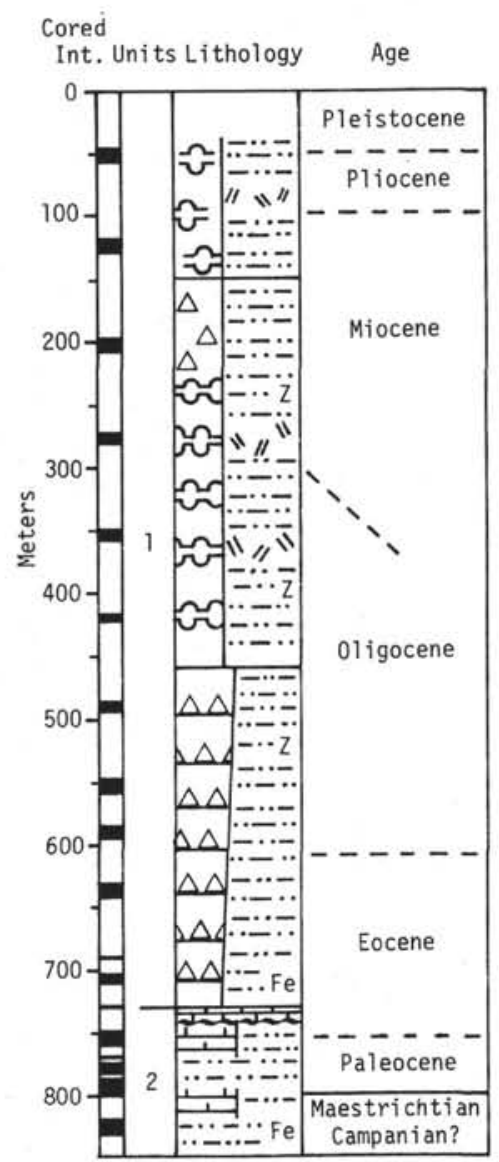


tions forced us to abandon the site without reaching basement or adding planned stratigraphic coverage.

\section{BACKGROUND AND OBJECTIVES}

Site 358 , in accordance with recommendations of the JOIDES Atlantic Advisory Panel, is in the northeastern Argentine Basin at latitude $37^{\circ} 39^{\prime} \mathrm{S}$, longitude $35^{\circ} 58^{\prime} \mathrm{W}$ (Figure 1). A major objective at this site was to date the basement (presumably oceanic basalt), in order to have a valid date at the older end of the magnetic reversal time scale of Heirtzler et al. (1968). The site is between the recently determined positions of anomalies 32 and 33 in the Argentine Basin (Figure 2). Before Leg 39, the earliest reliable date for the old end of the scale was Maestrichtian (67 \pm 1 m.y.B.P., anomaly 30 , Site 20 , Maxwell, Von Herzen, et al., 1970). At Site 355 in the Brazil Basin, basement was dated at 76-80 m.y.B.P. (early Campanian) between anomalies 33 and 34 . We knew, then, that basement age at Site 358 should be within the range determined by Sites 20 and 355, in which case we could be confident of having dated true basement rather than younger sills.
A second objective at Site 358 was to obtain a deepwater section for stratigraphic and biostratigraphic purposes, and in particular, to determine the nature and age of Horizon A. The stratigraphy of the Argentine Basin, as represented in seismic profile records (as, for example, the L-DGO reference profile, Figure 3, and the Glomar Challenger approach profile, Figure 4), is quite homogenous over the area of the basin, and consists of stratified sediments above Horizon A and a transparent section below, with a patchily distributed reflector just above basement. If Horizon A is analogous to Horizon A in the North Atlantic, it should be late Mesozoic or Early Tertiary in age (see discussion in Supko and Perch-Nielsen, this volume). The reflector cored at Site 328 on the Falkland Plateau and correlated with Horizon A represents increased lithification of an otherwise uniform clay unit approximately at the Cretaceous/Tertiary boundary.

The recommended site location was at 0245 hours on L-DGO record 119, Cruise V3101, 21 January 1974 (Figure 3). The location is 50 miles east of Site 331, Leg

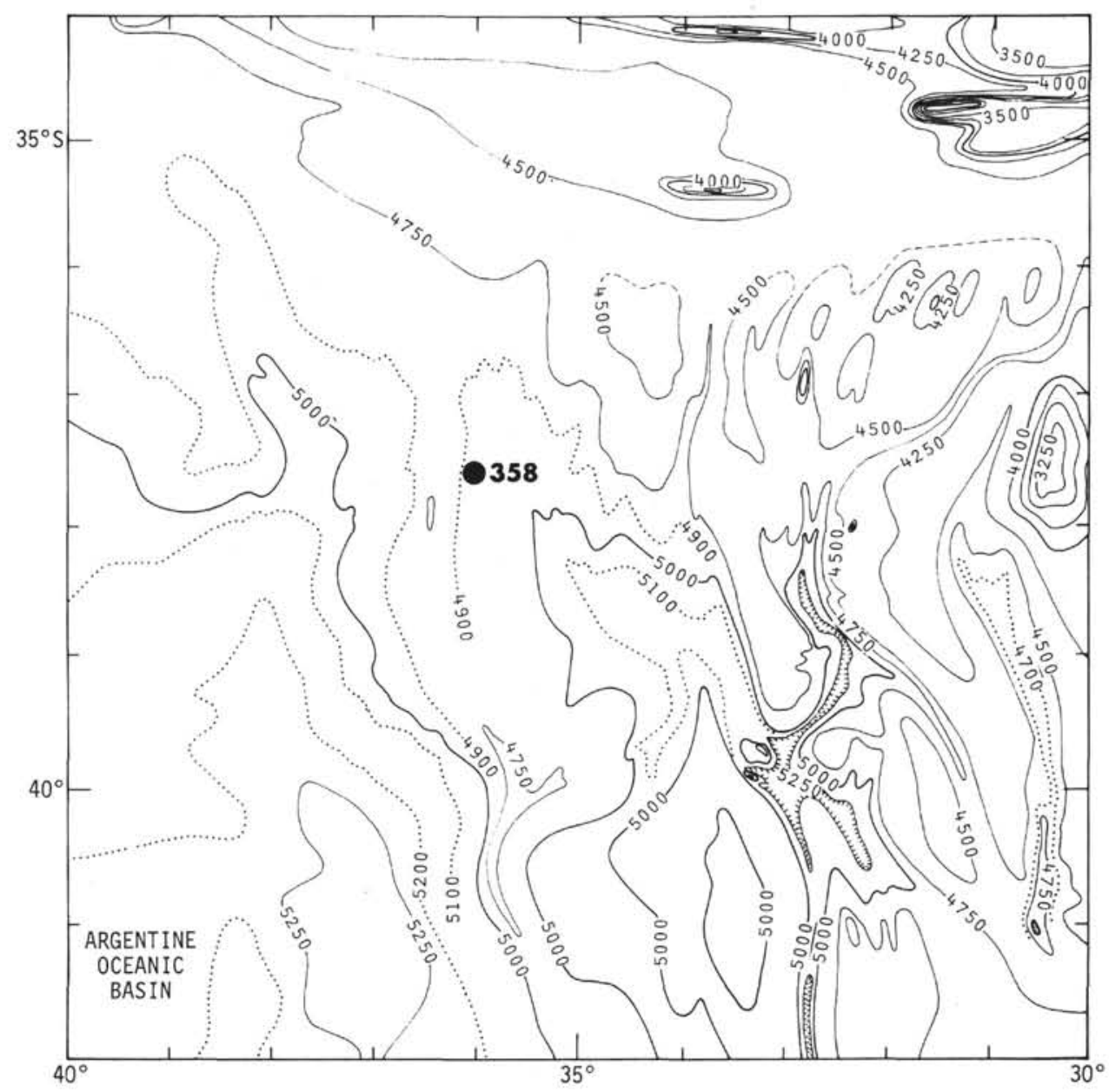

Figure 1. Base map of the northeastern Argentine Basin showing the location of Site 358. Contours in corrected meters. From unpublished L-DGO bathymetric chart of the Argentine continental margin. 


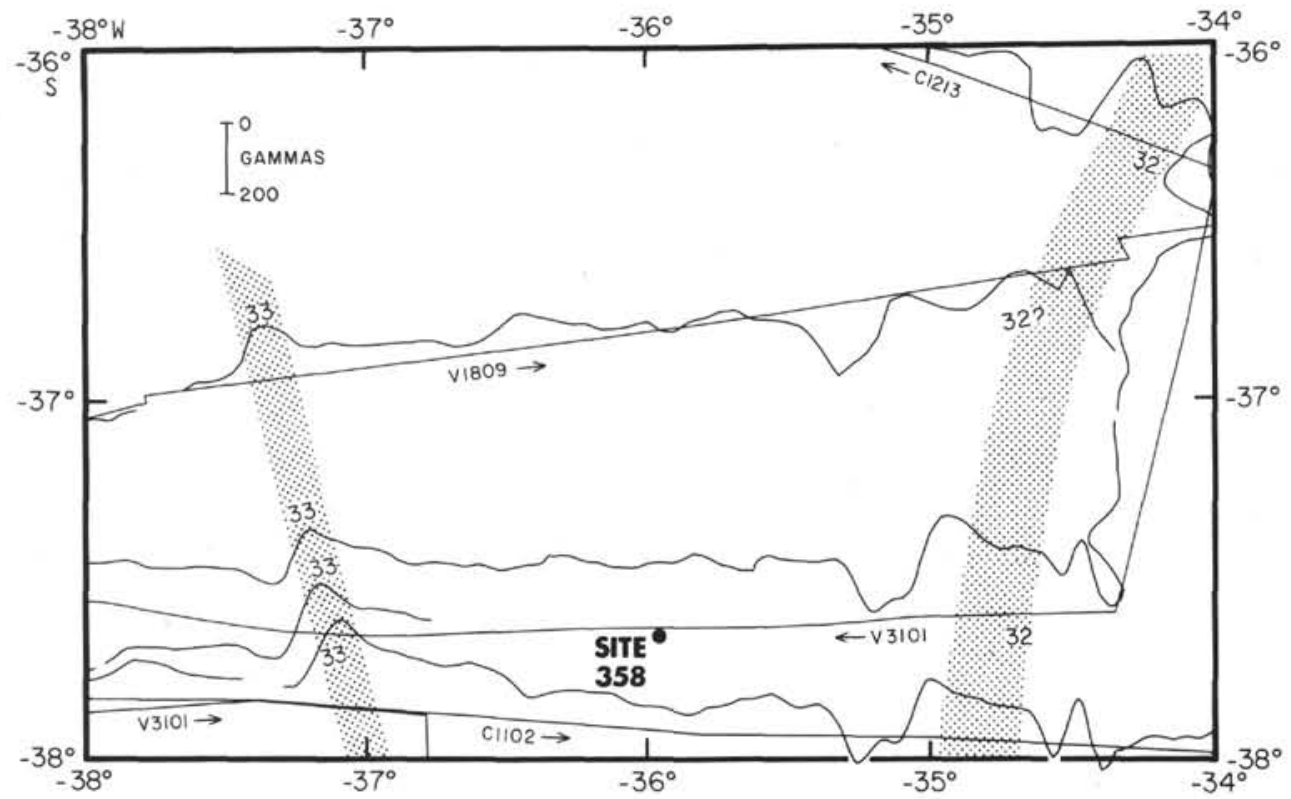

Figure 2. Location of Site 358 in relation to magnetic anomalies 32 and 33 as identified on $L-D G O$ cruise tracks by $R$. Larson (personal communication).

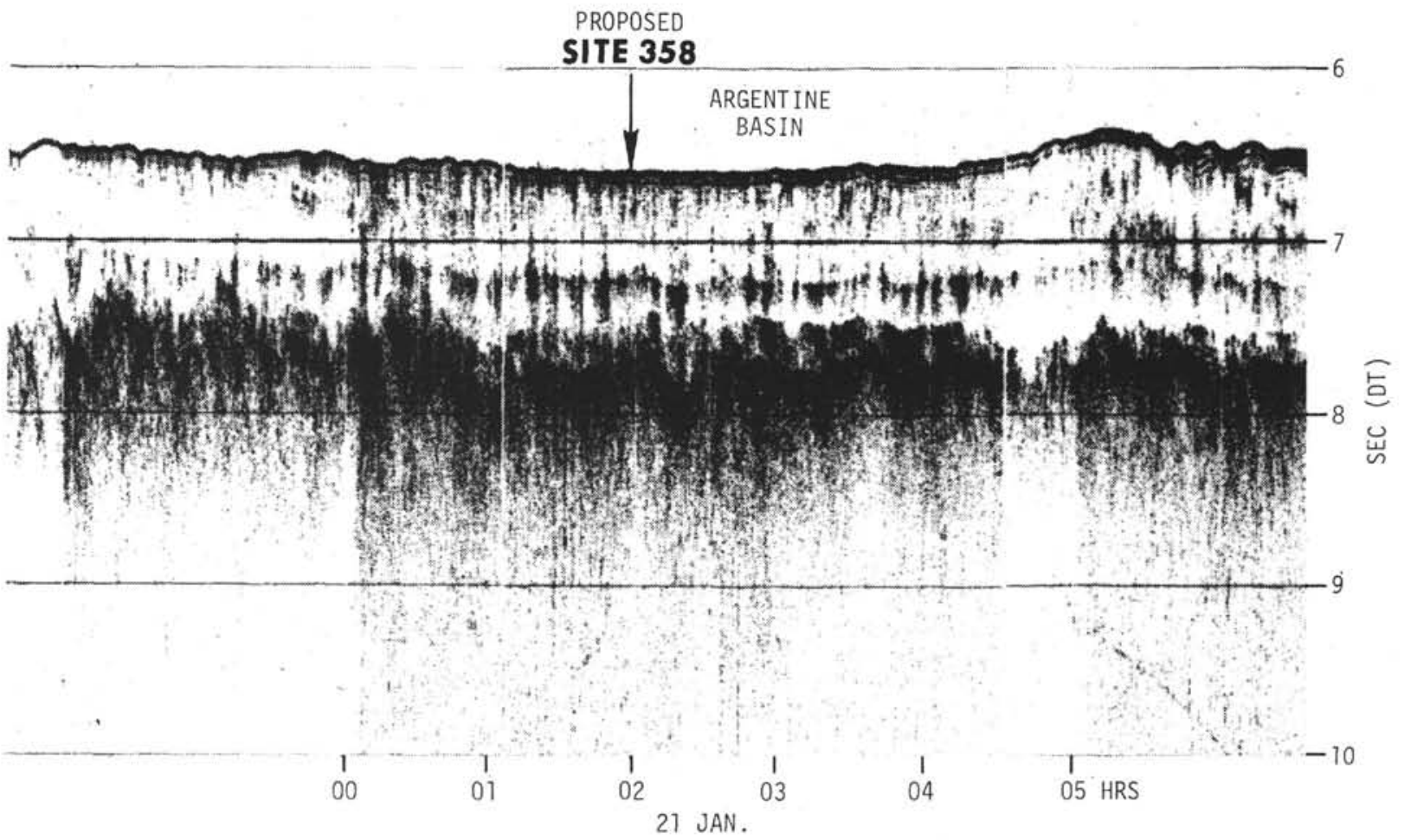

Figure 3. Site selection reference profile, 0245 hours, L-DGO Record 119, Cruise V3101, 21 January 74.

36 , which was abandoned for operational reasons after coring only the top 18 meters.

\section{OPERATIONS}

Glomar Challenger approached the vicinity of Site 358 on a course of $182^{\circ} \mathrm{T}$ from Site 357 on the Rio Grande Rise (Figure 5). At 0514Z, 30 November, we changed course to $268^{\circ}$ at a point approximately $37^{\circ} 38^{\prime} \mathrm{S}, 35^{\circ} 55^{\prime} \mathrm{W}$, to approximate the heading used by $\mathrm{R} / \mathrm{V}$ Vema when obtaining the seismic reflection reference profile (Figure 3), and reduced engine speed to $150 \mathrm{rpm}$ (ship speed about 6 knots). The approach profile approximated very closely the Vema profile; we selected a site that had about $1.0 \mathrm{sec}$ of sediment above basement and showed both reflectors A and B (Figure 4). At $0618 \mathrm{Z}$, we executed a Williamson turn and came 


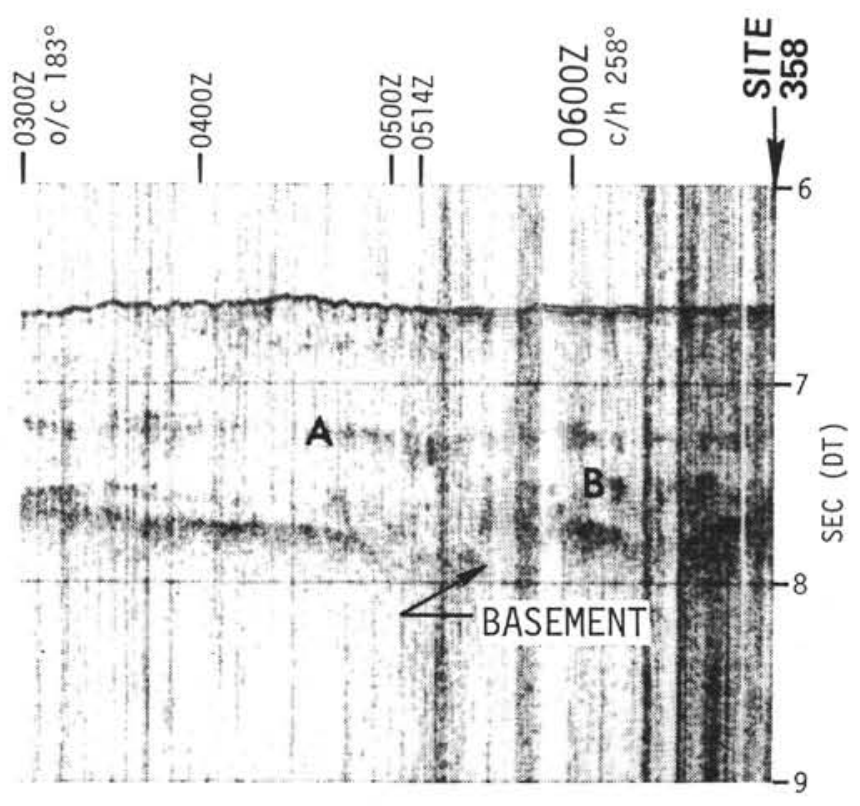

Figure 4. Glomar Challenger reflection profile obtained on approach to Site 358. Reflecting Horizons $A$ and $B$ shown.

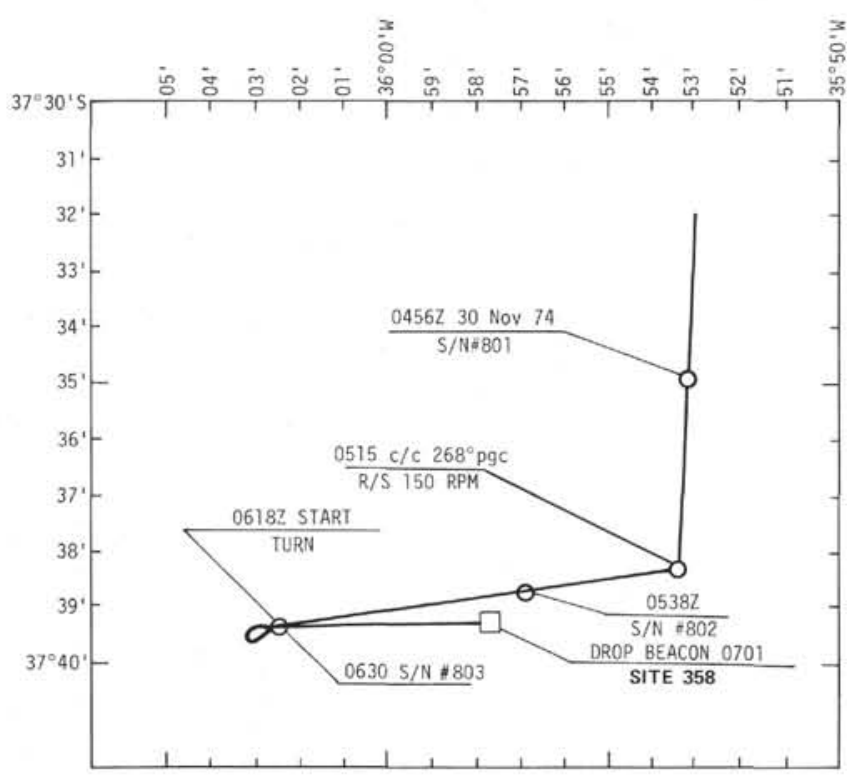

Figure 5. Glomar Challenger tracks on approach to Site 358.

back on a reciprocal heading at $0627 \mathrm{Z}$. We dropped the beacon while under way at $0701 \mathrm{Z}$, retrieved geophysical gear, and returned over the beacon. The final site location, based on 35 satellite navigation fixes, is $35^{\circ} 39.31^{\prime} \mathrm{S}, 35^{\circ} 57.82^{\prime} \mathrm{W}$.

The bottom-hole assembly used was the same as that on previous Leg 39 sites (see Site 356 report). The heave compensator was put in line, but failed to work when activated later in the drilling program. Water depth by PDR was 4956 meters, corrected, or 4972 meters to the rig floor. We spudded Site 358 at 1845 LCT, 30
November 1974; the driller reported feeling bottom at 5000 meters drill pipe measurement. The 28-meter discrepancy between pipe measurement and PDR measurement is greater than that at other Leg 39 sites and greater than that normally experienced in general. The driller may have encountered and not felt a soft bottom; but we decided to accept a water depth of 4990 meters.

In order to ensure reaching basement, we cored the upper section at fairly wide spacing; but spacing was somewhat closer in the vicinity of Horizon B and approaching basement. The coring plan was to fill stratigraphic gaps by spudding a second hole at this site. Depths of cores and recovery statistics are listed in Table 1; coring rates are plotted in Figure 6. The hole drilled and cored very quickly and easily in the relatively unconsolidated clay and siliceous clay above 460 meters, where coring rates exceeded 40 meters/hour, and drilling rates were higher still. The firmer clay sequence between 460 and 750 meters drilled well, coring at a rate of 20-30 meters/hour. Coring and drilling rates slowed considerably below 750 meters, because the sediment was chalk. Rates of penetration in chalk and limestones were low at earlier Leg 39 sites, and forced abandonment of Sites 356 and 357 because of time constraints.

For Cores 9 and above, we attempted to wash away the sediment in the drilled interval by using pump pressure, then took the core at the base of the interval. This works well in soft sediment, where it is very likely that we did collect in the last 9.5 meters, as intended. With a harder formation, however, the barrel is probably filled, at least partially, in the "washed" interval. So Cores 8 and 9 may have been collected anywhere between cored intervals 7 and 8 and 8 and 9 , respectively. Elsewhere when the formation was hard, we cored at the top of the section and completed the drilled interval with the core in the barrel, in effect using the sediment already in the barrel as a center bit. Where recovery was complete, it is fairly safe to assume that the sediment was collected, as intended, in the uppermost part of the sequence. Where it was less than complete, however, as in most of the section below Core 9 , it is more difficult to assign the sediment collected to a discrete zone of the cored plus drilled section.

At 0300 LCT on 3 December, we had just cut Core 16 at 817.0-826.5 meters, and were drilling two pipe lengths beyond. We were a calculated 50 meters above basement. With a higher drilling rate below Core 16, we were assured of reaching basement in the time remaining; we had requested a 24-hour extension of our ETA Cape Town, so that we could spud a second hole and add needed stratigraphic coverage at this site.

Weather had been worsening since midnight, and at 0400 hours we found we could no longer hold ship's position without taking power from the rig floor. In view of the bad weather, and to avoid the possibility of losing drillstring should the ship move from the beacon, we tripped to the mud line. Above the mud line, we continued to trip pipe slowly until we could get a reliable weather report. At 1230 LCT our weather 
TABLE 1

Coring Summary, Site 358

\begin{tabular}{lccccc}
\hline Core & $\begin{array}{c}\text { Depth From } \\
\text { Drill Floor }(\mathrm{m})\end{array}$ & $\begin{array}{c}\text { Depth Below } \\
\text { Sea Floor }(\mathrm{m})\end{array}$ & $\begin{array}{c}\text { Cored } \\
(\mathrm{m})\end{array}$ & $\begin{array}{c}\text { Recovered } \\
(\mathrm{m})\end{array}$ & $\begin{array}{c}\text { Recovery } \\
(\%)\end{array}$ \\
\hline 1 & $5047.5-5057.0$ & $47.5-57.0$ & 9.5 & 9.5 & 100 \\
2 & $5123.5-5133.0$ & $123.5-133.0$ & 9.5 & 6.2 & 65 \\
3 & $5199.5-5209.0$ & $199.5-209.0$ & 9.5 & 8.6 & 91 \\
4 & $5275.5-5285.0$ & $275.5-285.0$ & 9.5 & 2.6 & 27 \\
5 & $5351.5-5361.0$ & $351.5-361.0$ & 9.5 & 2.4 & 25 \\
6 & $5418.0-5427.5$ & $418.0-427.5$ & 9.5 & 3.0 & 32 \\
7 & $5484.5-5494.0$ & $484.5-494.0$ & 9.5 & 2.6 & 27 \\
8 & $5551.0-5560.5$ & $551.0-560.5$ & 9.5 & 8.5 & 89 \\
9 & $5589.0-5598.5$ & $589.0-598.5$ & 9.5 & 3.7 & 39 \\
10 & $5636.5-5646.0$ & $636.5-646.0$ & 9.5 & 9.5 & 100 \\
11 & $5703.0-5712.5$ & $703.0-712.5$ & 9.5 & 5.9 & 62 \\
12 & $5750.5-5760.0$ & $750.5-760.0$ & 9.5 & 8.6 & 91 \\
13 & $5779.0-5788.5$ & $779.0-788.5$ & 9.5 & 7.1 & 75 \\
14 & $5788.5-5798.0$ & $788.5-798.0$ & 9.5 & 5.9 & 62 \\
15 & $5798.0-5807.5$ & $798.0-807.5$ & 9.5 & 2.7 & 28 \\
16 & $5817.0-5826.5$ & $817.0-826.5$ & 9.5 & 2.5 & 26 \\
Total & & & 152.0 & 89.3 & 59 \\
\hline
\end{tabular}

forecast, based on two sequential satellite maps, was bad for at least the next 36 hours, so we had no choice but to abandon Site 358. We got under way toward Cape Town on course $085^{\circ}$ at 2012Z, 3 December 1974.

\section{LITHOLOGY}

We drilled one hole at Site 358 , to a maximum penetration of 842 meters, and recovered 16 cores at various intervals; the lowest core contained Upper Cretaceous sedimentary rocks. We distinguish two major lithologic units at this site (Figure 7, Table 2). Unit 1 consists of siliceous mud and mudstone of Pleistocene to mid-Eocene age (Core 1 to Core 11, Section 3). Unit 2 consists of terrigenous mudstone and marly chalk of middle Eocene to Late Cretaceous age (Core 11, Section 4 to Core 16).

\section{Unit 1}

Unit 1 is a dark greenish gray diatom-radiolarian mud, which becomes progressively firmer toward the base. Carbonate content is generally less than $5 \%$. The unit is divided here into five sub-units on the basis of degree of consolidation and diagenetic alteration of the biogenic siliceous component. Some of the sub-unit contacts are readily apparent in drilling rate and seismic reflection records, and others are arbitrarily placed. Unit 1 extends from at least 50 meters (the depth of Core 1) to 730 meters, and represents the interval from the (the Holocene or) Pleistocene to the middle Eocene.

Sub-unit $1 \mathrm{~A}$ includes Core 1 (upper Pleistocene and lower Pliocene) through Core 2 (upper Miocene). The base of the sub-unit is at 152 meters, the position of a prominent reflector. The sub-unit consists of unconsolidated diatom-radiolarian mud, generally dark greenish gray to greenish gray, with occasional black streaks and indistinct grayish olive-green layers. Few clear primary structures are visible; the muds have been disturbed by drilling.

The major constituent is undifferentiated clay, which ranges from $40 \%$ to $70 \%$. Silt-sized quartz decreases from $5 \%-15 \%$ in the upper portion to less than $5 \%$ at the base. Zeolites and volcanic shards occur throughout, and each makes up about 5\%. Siliceous biogenic material, up to $30 \%$, forms the other major component. Diatom remains generally average about $10 \%$, but constitute $25 \%$ of the sediment near the top of Core 1 ; radiolarians and sponge spicules make up about $10 \%$ to $15 \%$. Feldspar, mica, heavy minerals, and ferromanganoan grains occur in trace amounts throughout the unit. The coarse fraction consists of approximately equal amounts of fecal pellets and siliceous biogenic material.

Sub-unit 1A contains occasional indistinct areas or disturbed layers where the volcanic glass content is greater than average (up to $20 \%$ ) and where the silt content is $40 \%$. Blebs of Mn-rich material are present, and are generally smaller than $0.5 \mathrm{~cm}$ in diameter.

Sub-unit 1B, represented by Core 3 (mid-Miocene), is siliceous mud. It is greenish gray throughout, and contains black blebs and indistinct layering similar to sub-unit 1A. Clay makes up about $50 \%$ to $60 \%$ of the sub-unit; quartz, volcanic glass, feldspar, manganese oxides, and zeolites occur in trace amounts to $5 \%$. The coarse fraction, somewhat different from that of subunit $1 \mathrm{~A}$, contains phillipsite (?), fish debris, and teeth, in addition to fecal pellets.

A brownish gray layer with a greater than average quantity of quartz silt and volcanic glass is evident in Core 3. It is about 2 meters thick and grades upward into the dominant green-gray sediment, but its lower contact is sharp. Sub-unit 1B also shows infrequent burrow fill material of pale olive or yellowish gray. Smear-slide examination of this material reveals a $50 \%$ to $100 \%$ content of authigenic carbonate material, and variable percentages of clay, volcanic glass, and pyrite.

The major difference between the first two sub-units is the nature of the siliceous component. In sub-unit 1A the siliceous material consists of radiolarians, diatom remains, and sponge spicules, whereas in sub-unit $1 \mathrm{~B}$ silt-sized blebs of amorphous silica occur. This latter material apparently represents a diagenetic or partially 


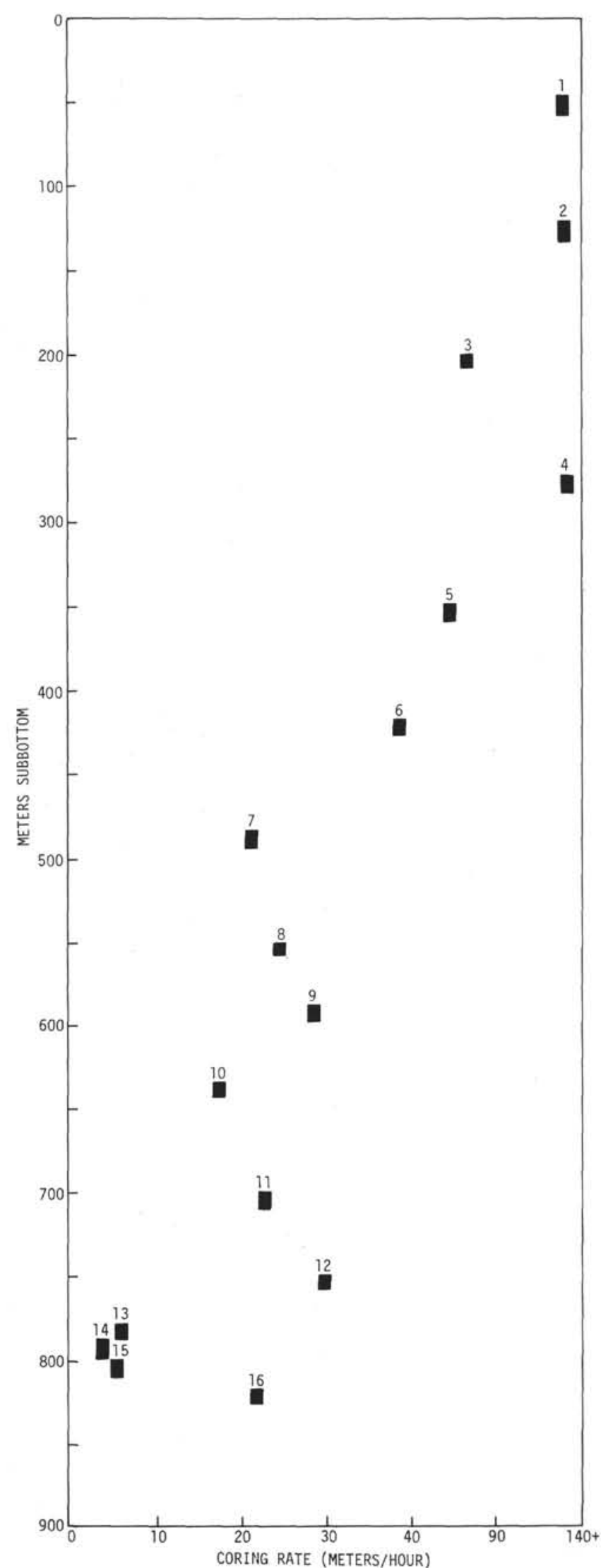

Figure 6. Coring rates, Site 358.

mobilized phase of the original biogenic silica. The coarse fraction contains some chert-like material, which appears to be altered but recognizable diatom and radiolarian fragments.

Sub-unit $1 \mathrm{C}$ includes the mudstones of Cores 4,5 , and 6 (lower Miocene-upper Oligocene), which extend from 220 meters to the Horizon A reflector at 460 meters. Macroscopically, the sub-unit is similar to the previous units, but its degree of consolidation differentiates it. Microscopically, it mose resembles sub-unit $1 \mathrm{~A}$, in that its siliceous material is biogenic-radiolarian remains for the most part, with fewer diatom frustules than in sub-unit 1A. Volcanic shards $(10 \%$ to $20 \%$ ) also distinguish it from the units above and below. Evidence of burrowing occurs in Core 4 and below, and well-formed Zoophycos burrows are prominent, especially in the lower sections. Some burrows have black halos. Nodular carbonate layers occur in the lower sections.

Sub-unit $1 \mathrm{D}$, represented by Cores $7,8,9$, and 10 (upper Oliogence to upper Eocene) is also green-gray mudstone. With its (probably altered biogenic) silica, it most resembles sub-unit 1B. Sediments from Cores 9 and 10 are almost completely barren; they contain only some pyritized radiolarians and palynomorphs. Horizon $A$ at this site $(460 \mathrm{~m})$ marks the boundary between sub-units $1 \mathrm{C}$ and $1 \mathrm{D}$, and is apparently a diagenetic change from silica clearly recognized as biogenic to altered silica present as amorphous silt-size masses (Figure 8).

Sub-unit $1 \mathrm{E}$ consists of ferruginous mudstone and is represented only by Sample 10, CC and the upper three sections of Core 11. Identification of the upper contact is based on a clear color change, but coring procedure does not allow precise placement; we have arbitrarily placed the contact at 690 meters.

Sub-unit $1 E$ probably represents a transition from the green-gray mudstones above to the colorful carbonates below; it shows some characteristics of both. Red, blue, and dark brown usually occur as indistinct zones, with no clear sedimentary structures. Sample 10, CC also has a distinct black layer containing large amounts of fecal pellets. Amorphous silica and clays are the primary constituents, as throughout Unit 1 . The coloring agents are finely dispersed, but recognizable as iron oxides. In Sample $10, \mathrm{CC}$, the coarse fraction contains phillipsite, fish remains, altered siliceous biogenic materials, volcanic glass, and barite crystals. The contact with Unit 2 is at the bottom of Section 11-3, and is clearly marked at the base of Unit 1 by up to 10\% dolomite rhombs (Figure 9) and the sudden increase of carbonate constituents in the unit below (see Figure 10).

\section{Unit 2}

We assign to Unit 2 the remainder of the section cored at this site. The position of the Unit 1/Unit 2 contact is somewhat in doubt, and may be an artifact of the coring procedure. The actual position of this boundary is, we believe, at approximately 730 meters, coincident with Horizon B reflector. Unit 2 is divided into two sub-units.

Sub-unit $2 \mathrm{~A}$ is represented only by Section $11-4$, and is responsible for the Horizon B reflector. It consists of a firmly indurated light brown marly chalk. The total carbonate content is about $50 \%$ to $60 \%$. Micarb and 


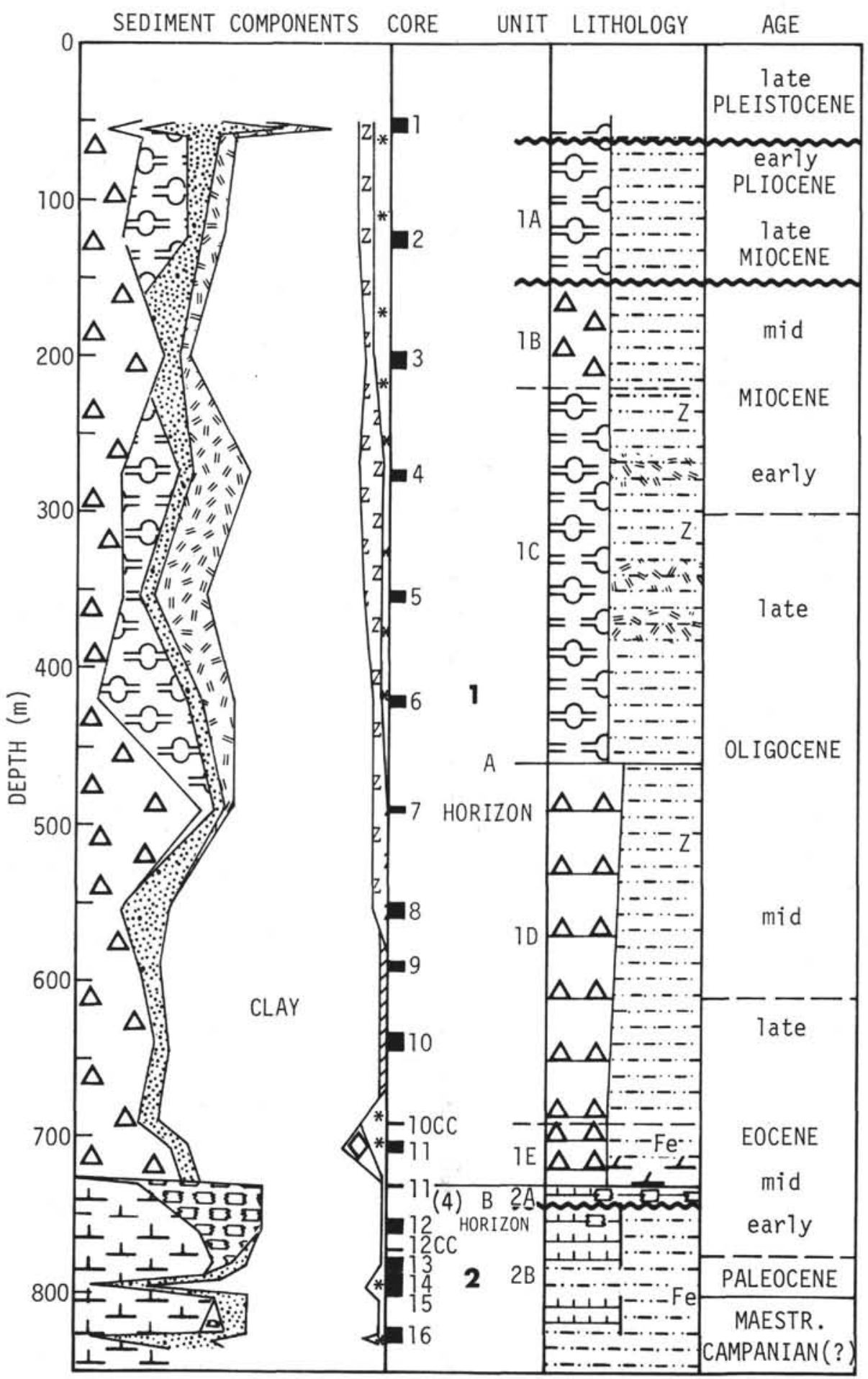

$\begin{array}{lccccc}1 & 1 & 1 & 1 & \\ 0 & 10 & 20 & 30 & 40 & 50 \\ 0 & \text { percent }\end{array}$

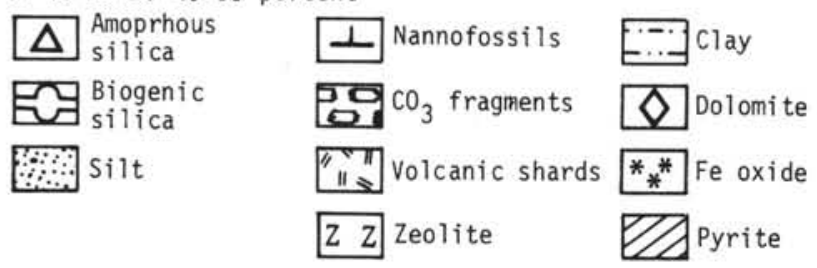

Figure 7. Lithologic summary, Site 358. 
TABLE 2

Lithologic Summary, Site 358

\begin{tabular}{|c|c|c|c|c|c|}
\hline Unit & Cores & $\begin{array}{l}\text { Depth Below } \\
\text { Sea Floor } \\
(\mathrm{m})\end{array}$ & $\begin{array}{l}\text { Thickness } \\
(\mathrm{m})\end{array}$ & Age & Description \\
\hline 1 & 1-11 (Sec. 3) & $0-730$ & 730 & $\begin{array}{l}\text { Pleistocene to } \\
\text { mid-Eocene }\end{array}$ & \\
\hline $1 \mathrm{~A}$ & 1,2 & $0-152$ & 152 & $\begin{array}{l}\text { Pleistocene to } \\
\text { late Miocene }\end{array}$ & $\begin{array}{l}\text { Radiolarian-mud: unconsolidated } \\
\text { silt and volcanic ash are common }\end{array}$ \\
\hline 1B & 3 & $152-220(?)$ & 68 & Miocene & $\begin{array}{l}\text { Unconsolidated, siliceous mud; } \\
\text { Amorphous silica and clay dominate }\end{array}$ \\
\hline $1 \mathrm{C}$ & $4,5,6$ & $220(?)-460$ & 240 & $\begin{array}{l}\text { Early Miocene to } \\
\text { late Oligocene }\end{array}$ & $\begin{array}{l}\text { Consolidated, radiolarian-diatom } \\
\text { mudstone volcanic ash common }\end{array}$ \\
\hline 1D & $7,8,9.10$ & $\begin{array}{l}\text {-HORIZON A- } \\
460-690 \text { (?) }\end{array}$ & 230 & $\begin{array}{l}\text { Late Oligocene } \\
\text { to late Eocene }\end{array}$ & $\begin{array}{l}\text { Siliceous mudstone, similar to Sub- } \\
\text { unit } 1 \mathrm{~B} \text {, lower portion barren }\end{array}$ \\
\hline IE & $\begin{array}{l}10, \mathrm{CC} \\
(\mathrm{Sec} .3)\end{array}$ & $690(?)-730$ & 40 & Mid-Eocene & $\begin{array}{l}\text { Ferruginous, siliceous mudstone; } \\
\text { with amorphous silica, dolomite } \\
\text { rhombs at base }\end{array}$ \\
\hline 2 & 11 (Sec. 4 -16 & $730-820+$ & $90+$ & $\begin{array}{l}\text { Mid-Eocene to } \\
\text { Late Cretaceous }\end{array}$ & \\
\hline $2 \mathrm{~A}$ & 11 (Sec. 4) & $730-740$ & 10 & Mid-Eocene & $\begin{array}{l}\text { Indurated, marly micarb chalk, } \\
\text { (light brown) }\end{array}$ \\
\hline 2B & $12-16$ & $\begin{array}{l}- \text { HORIZON B- } \\
740-820+\end{array}$ & $80+$ & $\begin{array}{l}\text { Early Eocene to } \\
\text { Maestrichtian- } \\
\text { Campanian }\end{array}$ & $\begin{array}{l}\text { Red-brown and blue-green calcareous } \\
\text { mudstones and marly nannofossil } \\
\text { chalks }\end{array}$ \\
\hline
\end{tabular}

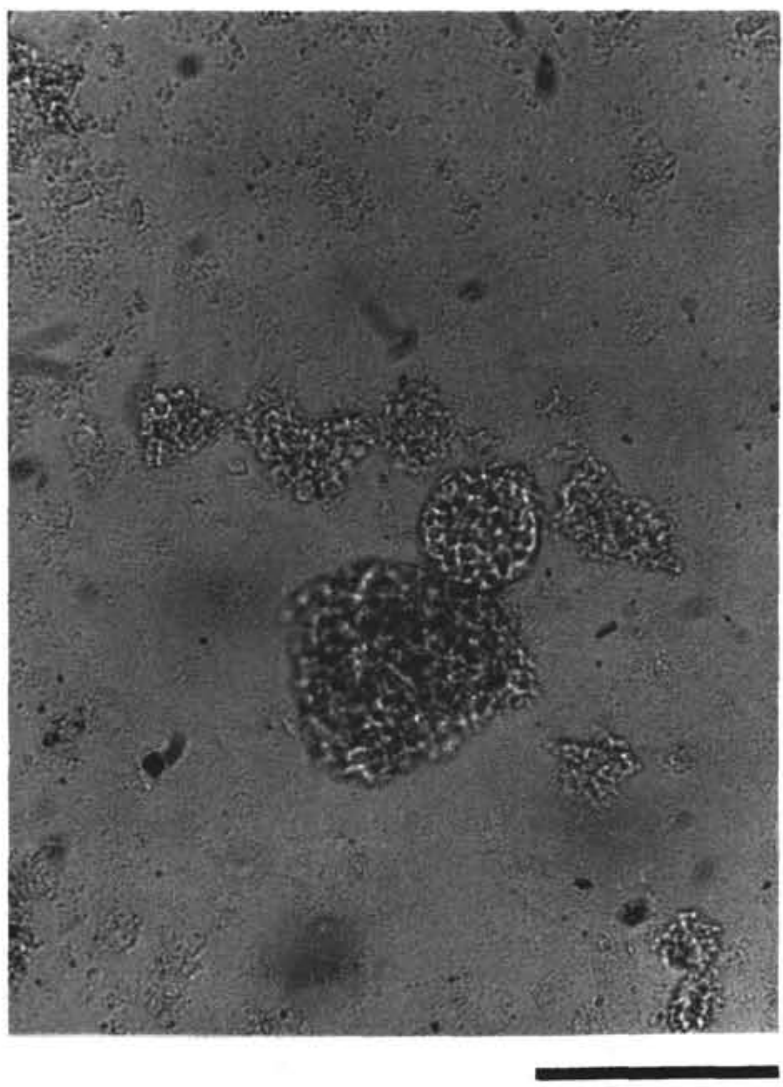

$0.1 \mathrm{~mm}$

Figure 8. Siliceous masses recognizable as biogenic in origin (Sample 358-7-2, $75 \mathrm{~cm}$ ). silt-sized carbonate fragments constitute $30 \%$ to $40 \%$ of the sediment, and poorly preserved nannofossils make up the remainder of the carbonate fraction. Clays dominate the rest of the sediment, which contains trace amounts of iron oxides, volcanic shards, and zeolite minerals.

Sub-unit 2B is represented by Cores $12-16$, the final cores at this site. The sediments are predominantly dark reddish brown, with intercalated areas of grayish bluegreen. Intercalations are best developed in Core 12, where the blue-green and reddish brown materials alternate. The color bands vary in thickness from about $10 \mathrm{~cm}$ to 1.5 meters, and in some bands appear mixed; the contacts are usually gradational but occasionally sharp. The blue-green color bands progressively decrease in abundance until only infrequent and indistinct areas occur toward the base of the section.

Sub-unit 2B consists of two rock types which are not always distinguished by their color. The first is a marly chalk containing between $50 \%$ and $70 \%$ carbonate material. Nannofossils range from $15 \%$ to $50 \%$, and microcarbonate material may range from $30 \%$ to $60 \%$. Foraminifers constitute $5 \%$ in Core 16 . Clay makes up about $30 \%$, and quartz silt occurs in trace amounts. Traces of feldspar, zeolite, authigenic silica, pyrite, and dolomite rhombs constitute the remainder. The facies is usually represented by the blue-green sediment, but may also be reddish brown, in which case iron oxides account for $5 \%$ of the sediment (based on smear-slide estimates).

The second rock type is mudstone consisting of 50\% to $75 \%$ clay, $5 \%$ to $25 \%$ quartz, and about $5 \%$ feldspar and zeolite. Traces of nannofossils and dolomite 


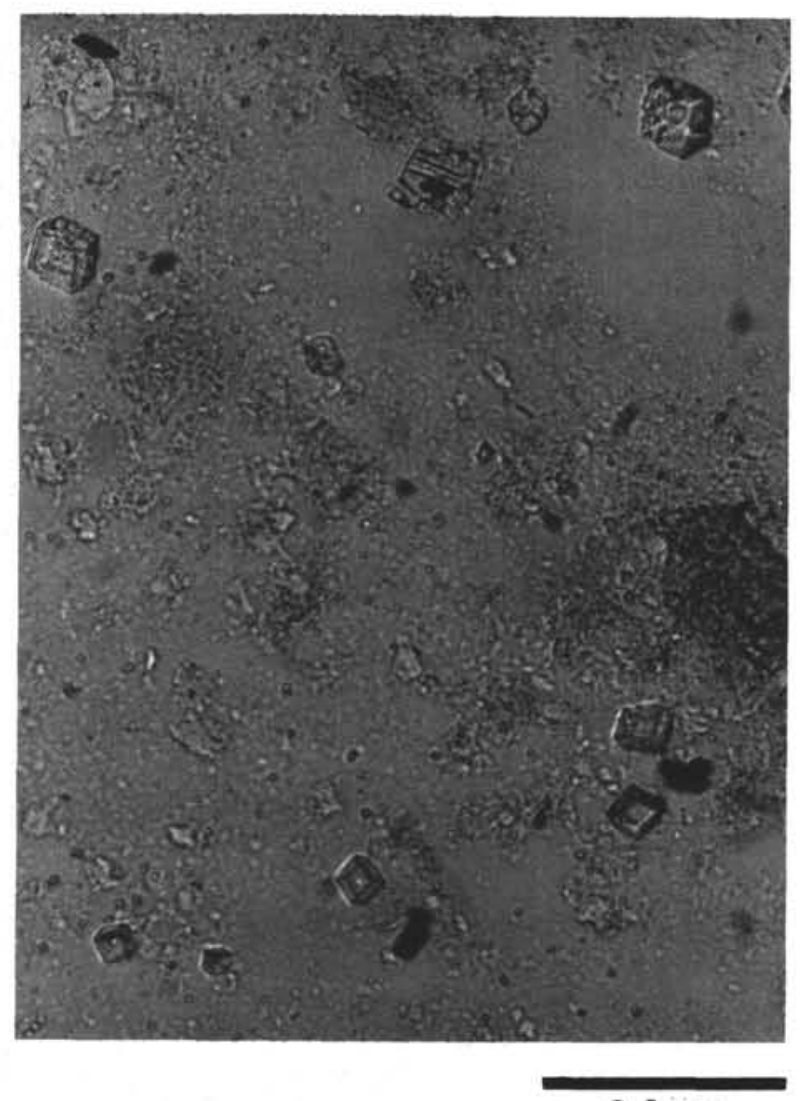

$0.1 \mathrm{~mm}$

Figure 9. Dolomite rhombs located at the base of Unit 1, above Horizon B (Sample 358-11-3, $48 \mathrm{~cm}$ ).

rhombs also occur. The color designation here is the reverse of the chalk facies. This lithologic type is usually reddish brown, but blue-green sediments of the same type occur. Where reddish brown, the sediment contains $5 \%$ to $10 \%$ iron oxide.

Barite, foraminifers, volcanic shards, mica flakes, and fish debris form the coarse fraction of sub-unit 2B. Core 12 also contains large fragments of carbonate material. Sub-unit 2B appears to be burrowed throughout, especially the reddish brown sediment. Sporadic laminae occur, usually in the blue-green material. Soft sediment deformation is also sporadic.

\section{Discussion}

The lowermost sediments recovered at Site 358 are ferruginous mudstones and marly chalks of Maestrichtian-Campanian to middle Eocene age. The chalks and mudstones seem to be intimately interbedded and mixed. They are predominantly reddish brown in the lower portion; indistinct blue-green areas and bands become more prevalent in the upper portion, especially in the lower Eocene (Core 12).

Sediments rich in iron oxides have been recognized at DSDP sites in all the major ocean basins. On this leg, we sampled ferruginous sediments in the Brazil Basin (355) and on the Ceará Rise (354). In most cases, these sediments were formed at or very close to the sediment/basalt contact. At Site 355, an intervening nannofossil ooze occurs between the basalt and the ferruginous sediments.

Boström and Peterson (1966), Boström et al. (1969), von der Borch and Rex (1970), and von der Borch et al. (1971) attribute the concentration and origin of amorphous iron oxides to sea water precipitation near the mid-ocean ridges as a result of volcanic exhalations. For Site 355, we infer hydrothermal metasomatic alteration of sediment, with the source of both the ferruginous material and the calcite veins being volcanically derived volatiles that pass upward through the sediment. This argument requires intimate contact of sediment with basalt basement and, in some cases, bypassing of a lower sediment unit not enriched in ferruginous material.

Another plausible explanation is that effusion of plateau basalts, often with production of associated laterite, would be widespread in conjunction with the initial rifting of the basin. The Kaoko basalts of southwest Africa, with a peak effusion at $125 \mathrm{~m}$.y.B.P. (Siedman and Miller, 1968), and the Serra Geral lavas of Brazil (Amaral et al., 1966) cover extensive areas on the South Atlantic margins, and may have provided a source of iron oxides, with detrital clay and amorphous iron oxides produced through an intermediate laterite stage. Deposition of ferruginous muds and chalks in the Upper Cretaceous and Paleogene seems usually to have been associated with a relatively slow accumulation rate (Sites 358, 355). Comparatively slow and finedetrital weathering of a basalt-laterite terrain would, therefore, seem reasonable for the South Atlantic at that time.

The alternating sequence of chalks and mudstones in Unit 2 implies a depositional surface approximately coincident with the CCD. Occasional fluctuations of the CCD are represented by alternating carbonate-rich or -poor sediments. The slow rate of accumulation suggests a basin with weak circulation and with increasingly open marine conditions as the basin developed.

The siliceous and biogenic siliceous mudstones of Unit 1 represent deposition below the CCD. The relatively high rates of accumulation imply that they are not pure dissolution facies, but rather the result of high productivity of siliceous organisms and perhaps introduction of terrigenous components by currents. The siliceous cement and matrix of sub-units $1 \mathrm{~B}$ and ID are presumably products of diagenetic remobilization of biogenic silica. The scattered pyrite and greenish color of Unit 1 sediments indicate a reducing environment. Burrows throughout the unit imply, however, that the water column was oxygenated to the bottom, allowing benthic life. Reducing conditions probably prevailed within the sediment column as a result of high organic productivity and consequent high rates of sedimentation. The Unit 1 sediments show no current structures and are fine grained. This is as expected, since the site is in the eastern part of the Argentine Basin, an area presently under the weak eastern arm (south-flowing) of the Argentine Bottom Gyre (Wüst, 1957), where fine-grain deposition from nepheloid layers is occurring (Ewing et al., 1971). Coarser terrigenous components are currently depositing in the more westerly areas of the basin, under westward- 


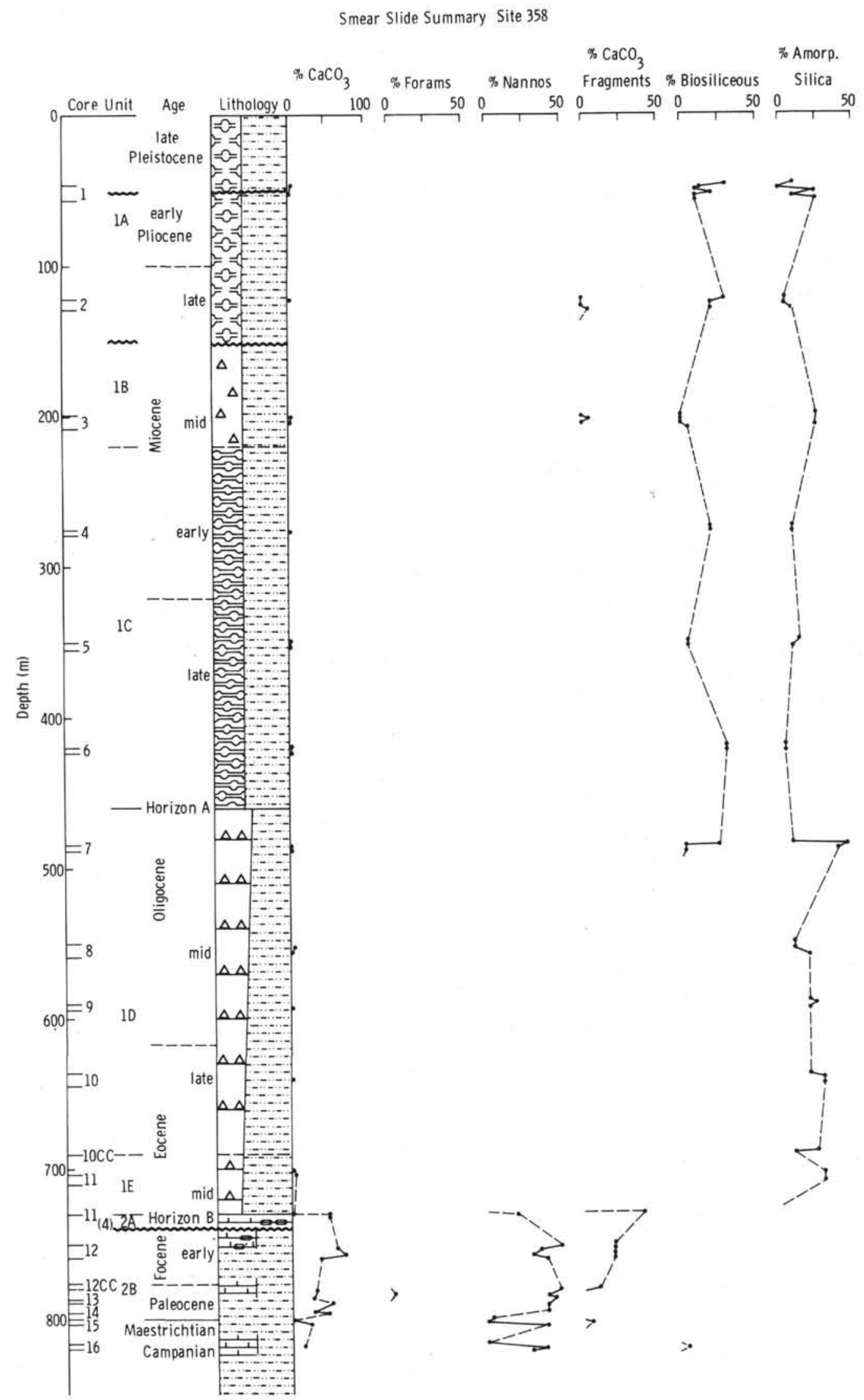

Figure 10. Smear slide summary, Site 358. 

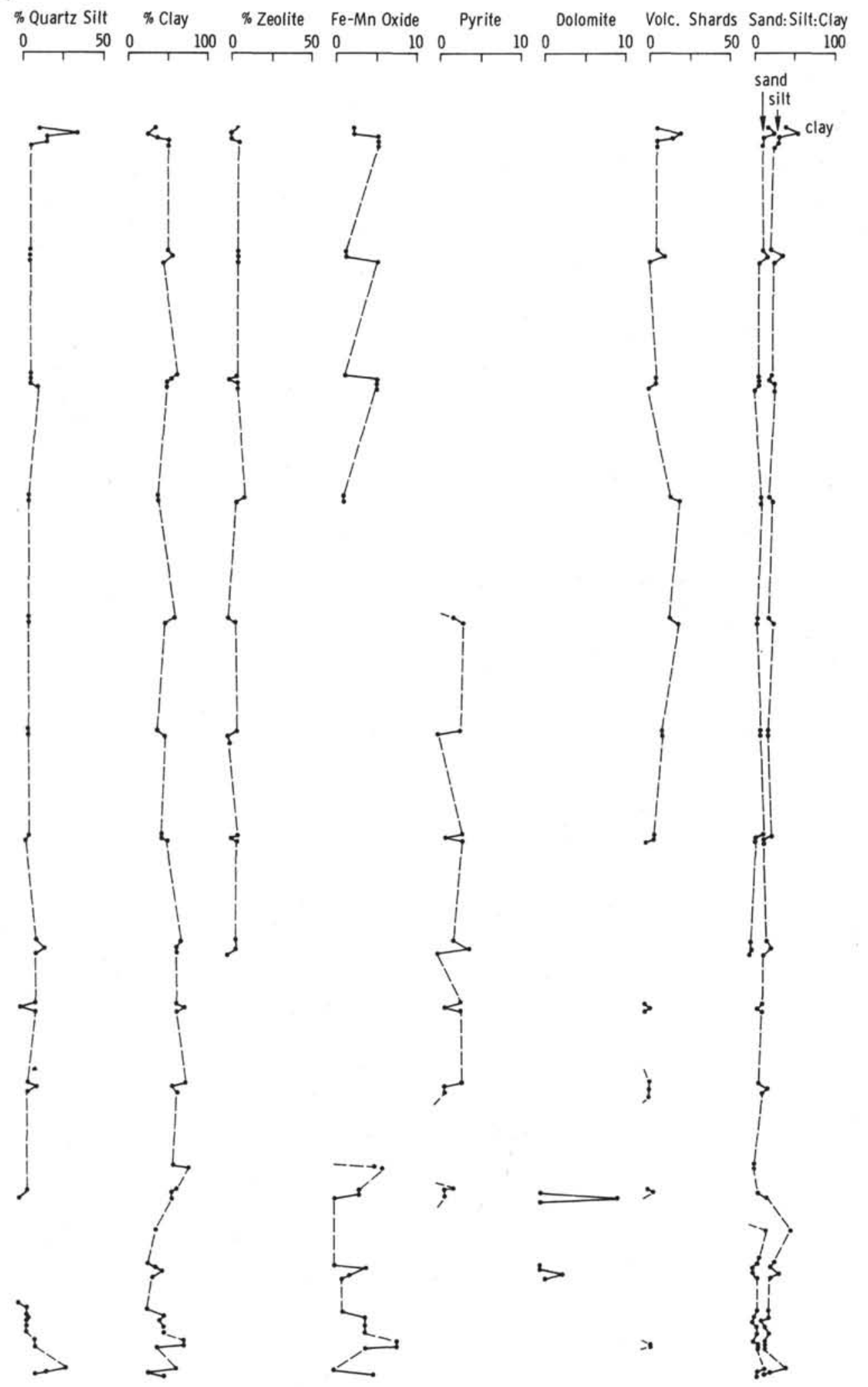

Figure 10. (Continued). 
intensified north-flowing bottom currents. At Site 331, west of Site 358 , silty muds and silts were recovered in the two surface cores.

\section{GEOCHEMISTRY}

We measured, aboard ship, the $p \mathrm{H}$, alkalinity, salinity, $\mathrm{Ca}^{++}$, and $\mathrm{Mg}^{++}$contents of nine interstitial water samples. Data are presented in Table 3 and Figure 11.

\section{PHYSICAL PROPERTIES}

Physical properties measurements at Site 358 are summarized in Table 4 and Figure 12. The cores were recovered at such widely spaced intervals that no detailed data are available on the variation of physical properties with depth. Nevertheless, some inferences can be drawn.

One of the primary objectives of drilling at Site 358 was to establish the nature of two prominent reflectors in the area, Horizons A and B. Horizon A may represent the contact between a diatom-radiolarian mudstone unit and an underlying siliceous mudstone. No significant change in velocity or water content occurs in the first of these units. The 2-minute GRAPE densities for Core 6 (at about $420 \mathrm{~m}$ ) are anomalously high. If these data are spurious, no density increase occurs above 450 meters either, and the diatomradiolarian mudstone may be described as uncompacted or uniformly compacted. The average velocity for this interval is $1.66 \mathrm{~km} / \mathrm{sec}$, the density (immersion) is near $1.53 \mathrm{~g} / \mathrm{cc}$, and the water content is about $44 \%$.

The properties of the underlying siliceous mudstone are markedly different: average velocity, density, and water content are $1.83 \mathrm{~km} / \mathrm{sec}, 1.88 \mathrm{~g} / \mathrm{cc}$, and $25 \%$, respectively. Further, acoustic velocity and density both increase with depth through the unit. Thus, the lower mudstone is more highly compacted than the overlying unit, and the contact between these units most probably correlates with Horizon A.

Horizon B probably represents the boundary between the mudstones and a unit, recovered in Core 11 , consisting of marly chalk. Velocity and bulk density increase distinctly across this boundary, from nearly 2.0 and $2.2 \mathrm{~km} / \mathrm{sec}$ and from 2.0 to over $2.2 \mathrm{~g} / \mathrm{cc}$, respectively; water content decreases from over $20 \%$ in the mudstone to less than $15 \%$ in the chalk unit. The discontinuity in lithology and physical properties occurs between Section 11-3 and Section 11-4, which is thought to have been recovered from a depth near 730 meters, rather than from the interval intentionally cored.

\section{BIOSTRATIGRAPHIC SUMMARY}

The location of this site, in the northeastern part of the Argentine Basin at a water depth of about 5000 meters, is reflected in the nature of the sedimentary sequence and its microfossil assemblages. Figure 13 shows the biostratigraphic units at this site.

TABLE 3

Summary of Shipboard Geochemical Data, Site 358

\begin{tabular}{ccccccc}
\hline $\begin{array}{c}\text { Sample } \\
\text { (Interval } \\
\text { in cm) }\end{array}$ & $\begin{array}{c}\text { Subdepth } \\
(\mathrm{m})\end{array}$ & $p \mathrm{H}$ & $\begin{array}{c}\text { Alkalinity } \\
(\mathrm{meq} / \mathrm{l})\end{array}$ & $\begin{array}{c}\text { Salinity } \\
(\% \circ)\end{array}$ & $\begin{array}{c}\mathrm{Ca}++ \\
(\mathrm{mmoles} / \mathrm{l})\end{array}$ & $\begin{array}{c}\mathrm{Mg}++ \\
(\mathrm{mmoles} / \mathrm{l})\end{array}$ \\
\hline $1-4,144-150$ & 53.5 & 7.51 & 4.70 & 35.2 & 11.56 & 50.23 \\
$2-3,144-150$ & 128 & 7.56 & 7.45 & 34.4 & 20.09 & 31.97 \\
$3-4,144-150$ & 205.5 & 7.74 & 6.70 & 32.4 & 22.64 & 24.48 \\
$6-2,140-150$ & 421 & 7.93 & 4.53 & 33.6 & 27.46 & 13.14 \\
$8-5,140-150$ & 558.5 & 8.15 & 2.28 & 33.0 & 30.49 & 9.28 \\
$9-2,140-150$ & 592.0 & 8.58 & 1.00 & 32.2 & 31.25 & 7.83 \\
$10-4,140-150$ & 642.5 & 8.60 & 1.00 & 30.8 & 35.06 & 5.00 \\
$11-2,140-150$ & 706.0 & 7.74 & 0.60 & 30.0 & 35.89 & 5.32 \\
$12-4,140-150$ & 756.5 & - & - & 31.1 & 40.38 & 9.65 \\
\hline
\end{tabular}
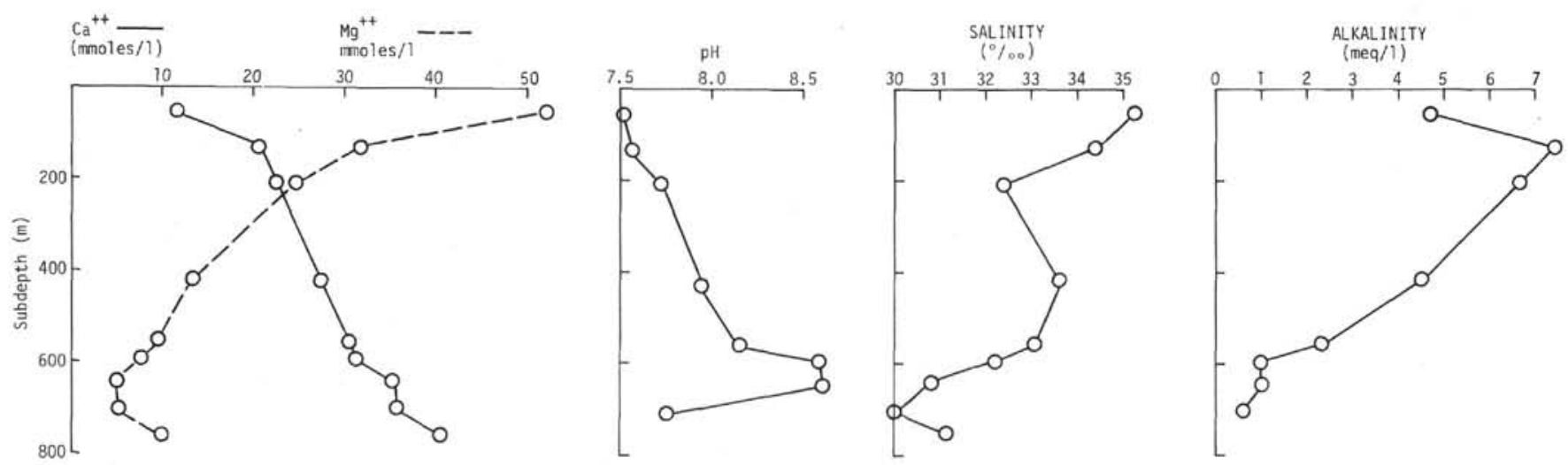

Figure 11. Geochemical parameters ( $\mathrm{pH}$, salinity, alkalinity, $\mathrm{CA++}$, and $\mathrm{Mg++}$ content) of interstitial waters versus depth; Site 358. 
TABLE 4

Physical Properties Data, Site 358

\begin{tabular}{|c|c|c|c|c|c|c|c|c|c|c|c|c|}
\hline \multirow{2}{*}{$\begin{array}{l}\text { Sample } \\
\text { (Interval } \\
\text { in } \mathrm{cm} \text { ) }\end{array}$} & \multirow{2}{*}{$\begin{array}{l}\text { Depth } \\
\text { (m) }\end{array}$} & \multirow{2}{*}{$\begin{array}{l}\text { Velocity } \\
(\mathrm{km} / \mathrm{sec})\end{array}$} & \multicolumn{3}{|c|}{ Density $(\mathrm{g} / \mathrm{cc})$} & \multirow[b]{2}{*}{$\mathrm{Wt} \%$} & \multicolumn{3}{|c|}{ Porosity (\%) } & \multicolumn{3}{|c|}{ Acoustic Impedance } \\
\hline & & & $\mathrm{S}$ & I & G & & $\mathrm{S}$ & I & G & $\mathrm{S}$ & 1 & G \\
\hline $4-1,140$ & 276.90 & 1.618 & - & 1.534 & 1.620 & 42.66 & - & 69.61 & 64.48 & - & 2.48 & 2.62 \\
\hline $4-1,92$ & 276.42 & 1.616 & - & 1.542 & 1.605 & 43.73 & - & 69.13 & 65.37 & - & 2.49 & 2.59 \\
\hline $5-1,139$ & 352.89 & 1.762 & - & 1.531 & 1.396 & 44.71 & - & 69.79 & 77.85 & - & 2.70 & 2.46 \\
\hline $5-2,107$ & 354.07 & 1.634 & - & 1.531 & 1.601 & 44.58 & - & 69.79 & 65.61 & - & 2.50 & 2.62 \\
\hline $6-1,7$ & 418.07 & 1.644 & - & 1.539 & 1.790 & 43.23 & - & 69.31 & 54.33 & - & 2.53 & 2.94 \\
\hline $6-2,136$ & 420.86 & 1.664 & - & 1.510 & 1.764 & 45.62 & - & 71.05 & 55.88 & - & 2.51 & 2.94 \\
\hline $6-3,147$ & 422.47 & 1.686 & - & 1.535 & 1.853 & 44.06 & - & 69.55 & 50.57 & - & 2.59 & 3.12 \\
\hline $7-1,149$ & 485.99 & 1.670 & - & 1.536 & 1.614 & 43.50 & - & 69.49 & 64.84 & - & 2.57 & 2.70 \\
\hline $7-2,145$ & 487.45 & 1.838 & - & 1.831 & 1.850 & 25.58 & - & 51.88 & 50.75 & - & 3.37 & 3.40 \\
\hline $8-1,147$ & 552.47 & 1.732 & - & 1.843 & 1.892 & 27.91 & - & 51.16 & 48.24 & - & 3.19 & 3.28 \\
\hline $8-3,147$ & 554.47 & 1.718 & - & 1.823 & 1.879 & 28.67 & - & 52.36 & 40.01 & - & 3.13 & 3.23 \\
\hline $8-6,146$ & 559.96 & 1.909 & - & 1.842 & 2.001 & 26.01 & - & 51.22 & 41.73 & - & 3.52 & 3.82 \\
\hline $10-1,81$ & 637.31 & 1.874 & - & 1.963 & 1.999 & 22.94 & - & 44.00 & 41.85 & - & 3.68 & 3.75 \\
\hline $10-3,137$ & 640.87 & 1.856 & - & 1.966 & 2.015 & 22.62 & - & 43.52 & 40.90 & - & 3.65 & 3.74 \\
\hline $10-6,5$ & 644.05 & 1.901 & - & - & - & 22.88 & - & - & - & - & - & - \\
\hline $11-1,37$ & 703.37 & 1.848 & - & 1.920 & 1.944 & 22.50 & - & 46.57 & 45.13 & - & 3.55 & 3.59 \\
\hline $11-3,2$ & 706.02 & 1.983 & - & 2.022 & 2.038 & 20.48 & - & 40.48 & 39.52 & - & 4.01 & 4.04 \\
\hline $11-4,147$ & 708.97 & 2.306 & - & 2.203 & 2.245 & 13.63 & - & 29.67 & 27.16 & - & 5.08 & 5.18 \\
\hline $12-1,47$ & 750.97 & 2.211 & - & 2.191 & 2.254 & 13.99 & - & 30.39 & 26.63 & - & 4.84 & 4.98 \\
\hline $12-3,148$ & 754.98 & 2.144 & - & 2.173 & 2.213 & 12.90 & - & 31.46 & 29.07 & - & 4.66 & 4.74 \\
\hline $12-6,140$ & 759.40 & 2.216 & - & 2.179 & 2.231 & 14.75 & - & 31.10 & 28.00 & - & 4.83 & 4.94 \\
\hline $13-1,80$ & 779.80 & 1.987 & - & 2.084 & 2.369 & 16.85 & - & 36.78 & 19.76 & - & 4.14 & 4.71 \\
\hline $13-5,2$ & 785.02 & 2.144 & - & 2.195 & 2.220 & 13.07 & - & 30.15 & 28.66 & - & 4.71 & 4.76 \\
\hline $13-0,0$ & 788.50 & 2.097 & - & 2.172 & 2.237 & 15.02 & - & 31.52 & 27.64 & - & 4.55 & 4.69 \\
\hline $14-1,46$ & 788.96 & 2.131 & - & 2.200 & 2.253 & 12.91 & - & 29.85 & 26.69 & - & 4.69 & 4.80 \\
\hline $14-2,147$ & 791.47 & 2.059 & - & 2.157 & 2.192 & 14.88 & - & 32.42 & 30.33 & - & 4.44 & 4.51 \\
\hline $14-4,146$ & 794.46 & 2.078 & - & 2.168 & 2.211 & 14.11 & - & 31.76 & 29.19 & - & 4.51 & 4.59 \\
\hline
\end{tabular}

NOTE: $\mathrm{S}=$ syringe technique, $\mathrm{I}=$ immersion technique, $\mathrm{G}=$ GRAPE.

Siliceous microfossils occur above 560 meters (Cores 1-8), whereas calcareous microfossils occur below 700 meters (Cores 11-16) and increase in abundance down the hole until it bottoms in lower Maestrichtian-upper Campanian marly chalks. The interval between 560 meters and about 720 meters (Cores 9, 10 and top of 11) is virtually barren; only infrequent pyritized and recrystallized radiolarians and some palynomorphs occur.

Although the cores come from widely spaced intervals, it appears that a fairly complete lower upper Paleocene to Pleistocene section is present at this site. However, there is some evidence for hiatuses or periods of very slow accumulation in the late Pliocene to early Pleistocene, the middle to late Miocene, in the late Eocene to the early Oligocene, and in the late early Paleocene to the early Eocene, depending on the interpretation of the timing and spacing of lithological changes (see Sediment Accumulation Rates). Unfortunately, because of poor preservation and/or solution of all microfossils, biostratigraphic control is rather poor for the sediments bracketing these intervals.

In general, rapid deposition well below the CCD occurred in the late Oligocene and Neogene (Cores 110). The dominance of heavier, robust radiolarians and sponge spicules in the biogenic component of the sediment indicates that solution of silica has occurred throughout the entire section. The diagenetic removal of biogenic silica has been particularly effective in Core 3 of middle Miocene age, and complete dissolution is evident in Cores 9 and 10, which could only be dated by palynomorphs to "Oligocene" and "upper Eocene," respectively (see Ioannides and Colin, this volume). Cores 11 to 16 contain no siliceous fossils, and the sediments are characterized by calcareous microfossils alternating with barren layers. Preservation of the calcareous microfossils varies from poor to moderate, and every assemblage shows evidence of solution. Intersection of the site with a fluctuating $\mathrm{CCD}$ allowed deposition of calcareous material in parts of the Eocene, early late Paleocene, and Cretaceous; solution characterized most of the early Paleocene (Boersma, this volume).

The calcareous microfossils indicate a hiatus or period of very slow accumulation at the Cretaceous/Tertiary boundary. Moderate to good preservation of the foraminifers and calcareous nannofossils indicates deposition above both the CCD and the lysocline during the late Campanian-early Maestrichtian. The benthic foraminifers throughout the calcareous sequence (Cores 11 through 16) are all abyssal forms.

The siliceous microfossil assemblages indicate cool to temperate conditions during the late Oligocene. The presence of collosphaerids in the early Miocene, as well as the dominance of tropical radiolarian species, indicates a warming trend in this part of the early Miocene. A return to cool conditions is evident in Cores 1 and 2 of late Miocene to Pleistocene age.

The predominance of siliceous microfossils in the Neogene sediments is a consequence of the prior events: (a) the great depth of deposition, well below the CCD since probably middle Eocene; (b) growth of the 

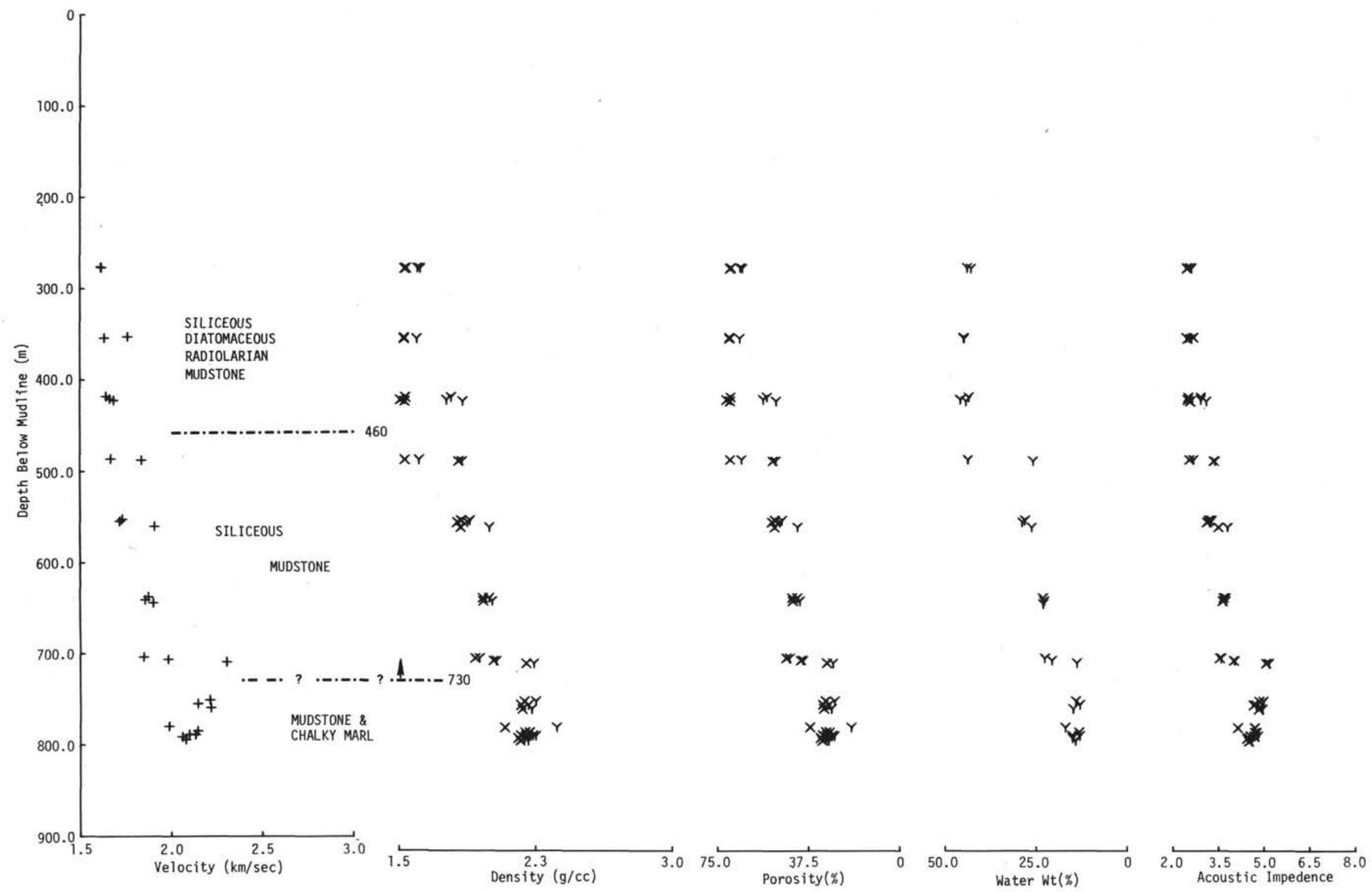

Figure 12. Physical properties versus depth;,$+ x$, and $y$ represent syringe, immersion, and GRAPE values, respectively. 


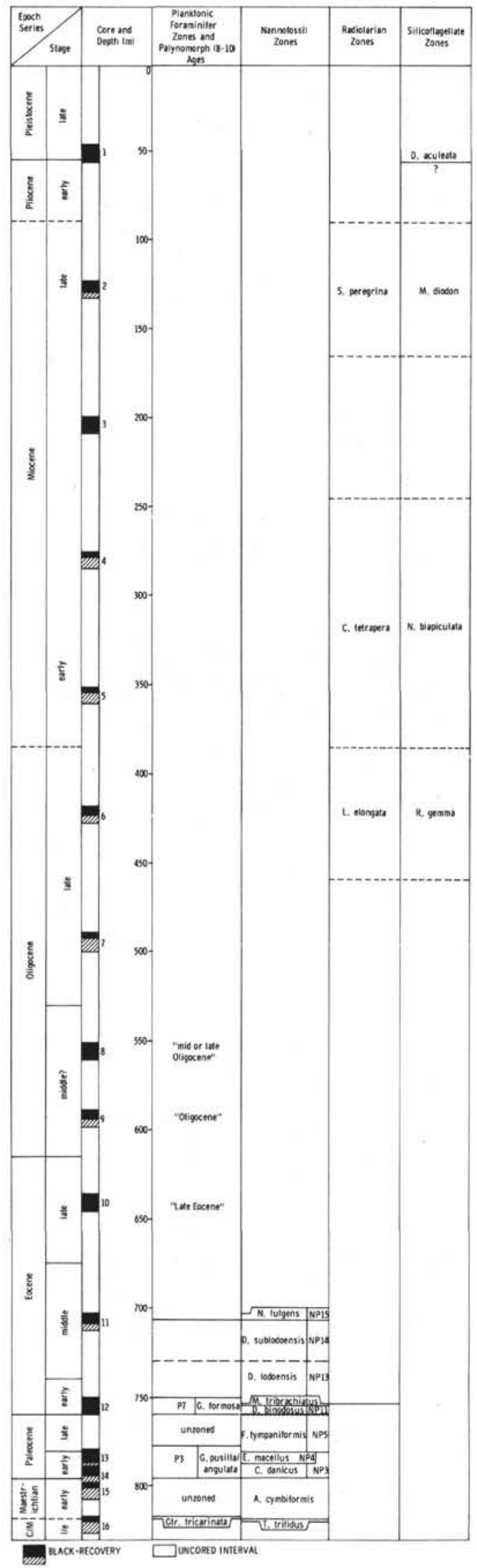

Figure 13. Biostratigraphic Summary, Site 358.
Antarctic Ice Sheet and generation of colder bottom water from Antarctica; and (c) initiation of the Antarctic Circumpolar Current with its associated high productivity of siliceous phytoplankton and microzooplankton. Northward flow of cold bottom water into the Argentine Basin had a profound effect on the deep circulation within this basin, and introduced a large amount of biogenic silica as an important new constitutent of the suspended sedimentary load. The rarity of siliceous microfossils in Core 3 (lower to middle Miocene) indicates an interruption in this sedimentary regime, possibly coupled with a reduction of surface productivity. An increase in Antarctic diatom species occurred from the late Miocene through the Pleistocene, as a result of cooling of the surface waters and intensification of the AABW.

Fish debris is present in varying amounts throughout the entire recovered sedimentary section, and may prove to be stratigraphically useful in the upper Eocene-lower Oligocene interval.

\section{Foraminifers}

We retrieved a small but interesting assortment of foraminifer faunas from Cores 11 through 16 at this site. Nearly all have been strongly altered by solution, and in many samples planktonic foraminifers have been entirely dissolved, leaving only benthic foraminifers and other microfossils in the residues.

\section{Core 7}

Sample 7, CC contains a few planktonic foraminifers, including Globorotalia (Turborotalia) opima nana and $G$. (T.) euapertura. This meager fauna occurs in a residue of organic debris which suggests deposition by turbidity current; it is probably Oligocene in age.

\section{Cores 11-14}

Cores 11 through 14 contain small assemblages of planktonic and benthic foraminifers. Both faunas have been generally depleted by intensive solution, leaving solution-resistant assemblages of low diversity. Planktonic species include Acarinina coalingaensis, $A$. densa, Globigerina (Subbotina) linaperta, G. (S.) primitiva, G. (S.) turgida, and Globorotalia (Morozovella) aragonensis. The benthic forms include deeper water species of Bolivinopsis, Nuttallides, Aragonia, Eggerella, and Pullenia. The age assigned to these faunas is early to middle Eocene.

In several samples from Cores 13 and 14 , faunas contain only benthic foraminifers; they are of Paleocene age, NP3/4 and NP5, according to the calcareous nannofossils.

\section{Cores 15-16}

The top of Core 15 contains no foraminifers. The lower sections, however, contain assemblages consisting only of deep water Cretaceous benthic foraminifers, including some very small faunas composed of Ammodiscus and some primitive agglutinated forms (see Sliter, this volume). We cannot assign ages to these faunas.

The bottom of Core 16, by contrast, contains a rich foraminifer fauna of a few planktonic species and many 
benthic species. Preservation of these fossils, however, is only moderately good. The planktonic species include Globotruncana tricarinata, G. arca, G. coronata, and Rugoglobigerina rugosas. Planktonic specimens are very few, and the entire smaller fraction of planktonic foraminifers is absent. The benthic fauna is rich in Gyroidinoides, Nutallinella, Dorothia, Aragonia, Pullenia, and Ammodiscus. The large size of several of the benthic specimens, along with a high abundance of mica in this sample, suggests redeposition of at least some of its components. We assign it to the lowermost Maestrichtian G. tricarinata Zone.

\section{Foraminifers and the CCD}

If, as we suppose, this site sank according to the model of oceanic crust of Sclater et al. (1971), then it can be shown that in its descent from a presumed ridge depth of 2700 meters in the earliest Maestrichtian (Core 16) to 4200 meters in the middle Eocene (Core 11), it intersected the lysocline and/or the CCD several times, thus indicating a fluctuation of the CCD (see PremoliSilva and Boersma, this volume, for discussion).

\section{Calcareous Nannofossils}

Calcareous nannofossils of middle Eocene to late Campanian-early Maestrichtian age occur in Cores 11 through 16. Cores 1 through 10 contain no calcareous nannofossils; this indicates that this site has been below the CCD since the mid-Eocene. Figure 13 summarizes the distribution of coccolith zones; tables in PerchNielsen (this volume) show the distribution of coccolith species.

\section{Eocene (Cores 11 and 12)}

The uppermost sample containing calcareous nannofossils (Sample 11-3,135 cm) includes only a few poorly preserved coccoliths of mid-Eocene age. The presence of Nannotetrina sp. assigns the assemblage to the $N$. fulgens Zone (NP15). Surprisingly, the assemblage contains only very few discoasters among the solutionaffected coccoliths. Discoasters usually become concentrated by solution of coccoliths. This may indicate that very few discoasters actually lived at the site at that time, and this in turn may indicate a cool environment. In the next older sample $(11-4,10 \mathrm{~cm})$, discoasters typical of NP14 are common, and the assemblage shows the "normal" characteristics of deposition below the lysocline and near the CCD: concentration of slightly overgrown discoasters, partly dissolved coccoliths, and no small or delicate large coccoliths. Overgrowth makes the identification of Discoaster sublodoensis, and thus the zone of this name, difficult. Marthasterites tribrachiatus is common from Sample 12-3, $54 \mathrm{~cm}$, on down through the rest of Core 12 , except in the core-catcher sample. It occurs with common D. lodoensis only in Sample 12-3, $54 \mathrm{~cm}$, and in one sample just $3 \mathrm{~cm}$ below. Below this level, $D$. lodoensis is absent or very scarce, although coccoliths and/or other discoasters are common; so the precise extent of the D. lodoensis Zone (NP13) and the top of the underlying $M$. tribrachiatus Zone (NP12) are difficult to establish. Discoaster binodosus, $D$. barbadiensis, and $D$. kuepperi are the other discoasters present in most samples. Chiasmolithus grandis/eograndis is not so common and large as at Site 357 on the Rio Grande Rise, and it is impossible to estimate a discoaster/chiasmolith ratio as a climatic indicator because of poor preservation of the chiasmoliths, most of which lack their central structure. The question of the significance of this ratio is discussed in Perch-Nielsen (this volume). The generally poor assemblages also lack Zygrhablithus bijugatus, a form common in the Eocene at Site 357.

\section{Paleocene (Cores 12 to 14 )}

The core-catcher sample of Core 12 contains a Paleocene coccolith assemblage. The core-catcher sample was probably picked up at the bottom of the interval drilled with the core barrel in place after coring, in which case it represents material as far as 19 meters below the rest of Core 12. It is not possible from our data to conclude whether there was a hiatus spanning up to $7 \mathrm{~m}$.y. of the earliest Eocene and the late Paleocene, or whether accumulation was very slow during this period. Sample 12, CC and the uppermost sample in Core 13 contain a well-preserved assemblage typical of the Fasciculithus tympaniformis Zone (NP5). Infrequent and very large forms similar to $F$. tympaniformis also occur in Sections 13-2 and 13-3, which are considered to belong to the Chiasmolithus danicus Zone s.l. (including also the Ellipsolithus macellus Zone, since no E. macellus or E. distichus were found, probably because of solution), as is the rest of the core Core 14 . Toward the bottom of Core 14, C. danicus becomes infrequent, Cruciplacolithus tenuis increases in number, and the size of all coccoliths decreases. This is typical for the lowermost part of the Danian sequence, just above the $C$. tenuis Zone (NP2) which usually is very thin (less than 1 to $2 \mathrm{~m}$ ), as is the Markalius inversus Zone (NP1). The Danian assemblage here is different from the others seen on this leg (Sites 354, 356, 357), in that Thoracosphaera, which usually occurs in large amounts in the Danian of high and low latitudes, here is very scarce. The same is true for forms of Neochiastozygus. This may indicate that both Thoracosphaera and Neochiastozygus are genera preferring shelf or slope environments rather than an open ocean environment such as is assumed for this site in the Danian. The absence in some samples of small coccoliths that are usually abundant in the Danian is considered to be a consequence of solution or washing rather than other environmental factors.

\section{Cretaceous/Tertiary Boundary and Cretaceous}

The core-catcher sample of Core 14 is barren of calcareous nannofossils, as are most samples from the top part of Core 15. The latter core was taken just below Core 14, but contained only 2.7 meters of the 9.5 meters of sediment cored. The Cretaceous/Tertiary boundary occurs somewhere in the cored but unrecovered interval, since the uppermost fossiliferous sample of Core 15 includes scarce Maestrichtian forms only. Site 358 must have been at a depth sometimes above, sometimes below the CCD during the latest 
Maestrichtian-earliest Tertiary. The coccolith assemblages of Core 15 have been strongly affected by solution, so that only abundant Micula staurophora and very scarce parts of shields of other coccoliths are left. The presence of parts of Arhangelskiella cymbiformis and the absence of Micula mura and Lithraphidites quadratus suggest that the youngest Cretaceous calcareous sediments in Core 15 and all of Core 16 except the core-catcher sample belong to the $A$. cymbiformis Zone of the middle to early Maestrichtian age. It is possible that the absence of $M$. Mura and/or $L$. quadratus-indicators of younger Maestrichtian-is not primary absence but a result of solution. The corecatcher sample of Core 16 again shows an assemblage different from those within the core. We assume that the sediment in the core catcher was picked up about 19 meters below the interval over which Core 16 was cut-i.e., represents a sample from the very bottom of Hole 358. Sample 16, CC contains a diverse, reasonably well-preserved coccolith assemblage belonging to the Tetralithus trifidus Zone of early Maestrichtian/late Campanian age. The red as well as the gray marl samples contain scarce to few Kamptnerius magnificus and $A$. cymbiformis, species absent or very uncommon at other open ocean sites. Clearly Site 358 was above the CCD and probably above the lysocline during late Campanian-earliest Maestrichtian time.

\section{Radiolaria}

Siliceous microfossils of Pleistocene to late Oligocene age occur in Cores 1 through 8 . In these cores, the radiolarians are generally the most abundant siliceous microfossils; few to common diatom remains and scarce to few silicoflagellates also occur. Sponge spicules are present in varying abundance in all of the above cores. Preservation of the radiolarians in these cores varies from moderate to good in Cores 1 and 2 and 4 through 6; it is poor in Cores 7 and 8 . Extensive dissolution is evident in Core 3. Diversity follows the same trend. Siliceous microfossils are essentially absent in Cores 9 through 12, except for very scarce pyritized and recrystallized radiolarians. No radiolarians occur in Cores 13 through 16.

Core 1 contains an assemblage of Pleistocene age; Sample 1, CC is early Pliocene in age. The general character-for example, the presence of Theocorythium trachelium dianae-indicates temperate to cool waters. But most Antarctissa species, which are so common in the circum-Antarctic sediments of that age, are missing. The radiolarians seem to span only a limited size range. This, coupled with the apparent dominance of fairly robust forms, indicates that the assemblage may have been modified by current action and dissolution processes at the sea floor.

A late Miocene temperate to cool assemblage of the $S$. peregrina Zone is present in Core 2. Actinomma tanyacantha, Cannartus laticonus, Cannartus sp. cf. $C$. laticonus, Stichocorys peregrina, Lychnocanoma grande rugosum, Lophoconus miocenica, and Cyrtocapsella tetrapera are all present, but again the Antarctissa group is absent, as is Theocalypytra bicornis spongothorax, the late Miocene nominate species for high southern latitude radiolarian zonation. As in Core 1, the robustness of most specimens present may point to the effects of lateral transport and solution.

Only a few radiolarians are present in the corecatcher sample of Core 3 . Infrequent $C$. tetrapera occur, along with fragments and spines of orosphaerids, mainly of Oroscena sp., $O$. carolae and scarce Orodapsis sp. All these species range from the lower Miocene to at least the lower upper Miocene. Solution and migration of the biogenic silica has taken place in this interval; only the most solution-resistant species, the orosphaerids, remain, together with sponge spicules.

Cores 4 and 5 are assigned to the lower Miocene $C$. tetrapera Zone of Chen (1975). Collosphaerids occur in both cores, and this indicates warmer surface waters.

Of the assemblages in Cores 6, 7, and 8, only those of Core 6 could be assigned to a zone, namely the $L$. elongata Zone. Radiolarians do, however, indicate a late Eocene age for Section 7-1. The assemblages are quite unlike those from the Eocene-Oligocene tropicalsubtropical regions, and seem to bear only superficial resemblance to the Oligocene assemblages recovered on Leg 36 on the Falkland Plateau. But the infrequent occurrence of Dorcadospyris ateuchus, Cannartus prismaticus, index fossils of Riedel's zonation, and Cyrtocapsella semipolita, Cyclampterium sp. aff. C. milowi and Cyclampterium sp. aff. C. pegetrum indicate a late Oligocene age for these assemblages. Since they do not unequivocally indicate either a warm or a cool environment, a region of mixing of cool and warm water masses may best explain these faunas.

\section{Silicoflagellates}

Silicoflagellates occur in samples of Cores 1, 2, 4, 5, 6 , and the top of Core 7. They are uncommon in these samples, which also contain common diatom remains. No silicoflagellates occur where diatoms are scarce and poorly preserved.

In Sections 1-1 through 1-3, the assemblage consists only of the species Distephanus speculum, Dictyocha aculeata, and $D$. aspera. In all three samples, silicoflagellates are much too infrequent to conclude much about water temperatures, Dictyocha suggests warmer waters than D. speculum. Diatom remains in Sections 11 through 1-4 indicate these sections are of late Pleistocene age (Fenner, this volume) and belong to the $D$. aculeata Zone. No silicoflagellates occur in the remainder of Core 1, which we assign, on the basis of diatom remains, to the lower Pliocene to upper Miocene.

In Core 2-which we date as late Miocene on the basis of radiolarians and diatom remains and the presence of Mesocena diodon-four samples contain infrequent silicoflagellates and the endoskeletal dinoflagellate Actiniscus pentasterias.

All samples studied from Core 4 contain scarce silicoflagellates, and are assigned an early Miocene age on the evidence of radiolarians and the presence of Naviculopsis lata in Sample 4, CC. The assemblages are slightly richer than in the younger samples. $A$. pentasterias, Carduifolia gracilis, and infrequent ebridians also occur. Scarce Rocella gemma occur in Sample 4-2, $130 \mathrm{~cm}$ and in Sample 4, CC. 
Only the core-catcher sample of Core 5 contains scarce silicoflagellates: $D$. speculum, $D$. crux, Dictyocha medusa, Cannopilus hemisphaericus, $N$. biapiculata, $N$. cf. N. lata and Septamesocena apiculata. A. pentaradiatus, Carduifolia sp., and very infrequent $R$. gemma also occur.

A relatively rich assemblage occurs in Core 6 , especially in Sample 6-1, $46 \mathrm{~cm}$. Common $R$. gemma indicates a latest Oligocene age for this sample, which otherwise contains an assemblage similar to that in Sample 5, CC. Additional species here are Corbisema archangelskiana and Ammodochium rectangulare.

In Core 7, silicoflagellates occur only in Sample 1, 58 $\mathrm{cm}$. The assemblage is similar to the one in Core 6. This sample also includes a few archaeomonads, whose absence is surprising in the other Oligocene and Miocene samples, but which is probably a consequence of dissolution rather than adverse climatic conditions. Few $R$. gemma may indicate a late Oligocene age for this sample.

We may assign the cores to the following silicoflagellate zones of Perch-Nielsen (1975):

\begin{tabular}{ll} 
Core & \multicolumn{1}{c}{ Zone } \\
& \\
1 & D. aculeata \\
2 & M. diodon \\
4,5 & N. biapiculata \\
6 & R. gemma \\
7 & D. medusa $(?)$
\end{tabular}

$\quad$ Age
late Pleistocene
late Miocene
mid- and early Miocene
late Oligocene
late Oligocene

\section{Diatoms}

According to Fenner (this volume), diatom remains in Cores 1 and 2 are generally scarce and moderately to poorly preserved, except in Section 1-3, where they are common to frequent and moderately to well preserved. The diatom assemblages of Sections 1-1 through 1-4 can be assigned to the Coscinodiscus lentiginosus and the C. elliptipora/Actinocyclus ingens zones of McCollum (1975), which were correlated with the Brunhes and upper Matuyama epochs. Sections 1-5 and 1-6, on the other hand, could be of earliest Pliocene or even latest Miocene age, on the evidence of Denticula hustedtii and other Miocene species, and the absence of Coscinodiscus lentiginosus and Nitzschia kerguelensis, which first occur in the upper Pliocene. Thus a minor hiatus, including at least the upper Pliocene and the lowermost Pleistocene, is indicated between Sections 14 and 1-5. This unconformity may be a result of an increase in the AABW flow eroding or at least hindering deposition at this site. Or the hiatus may be a coring artifact, since Core 1 was taken at 47.5-57.0 meters after washing down from the surface to this depth with the core barrel in place. The $D$. hustedtii Zone of McCollum (1975), represented in Core 2, suggests a late Miocene age for that core.

Gradual cooling from the late Miocene to the Pleistocene (Shackleton and Kennett, 1975) can be traced by the relative abundance of endemic antarctic species. The increase of antarctic species occurring at this site in the northern part of the Argentine Basin is a consequence of surface water cooling and of intensified generation of $\mathrm{AABW}$ which transports antarctic floral elements northward (Burckle, in Groot et al., 1967; Burckle and Stanton, 1975).

\section{Palynomorphs}

Ioannides and Colin (this volume) studied palynomorphs in Cores 5 through 10 , which contain no calcareous microfossils; they found a general lack of terrestrially derived microfossils and a limited diversity of the microplankton population indicative of an open marine depositional environment. Core 5 contains Deflandrea phosphoritica and Tuberculodinium vancampae; to date, the former has not been reported from Miocene sediments, and the latter is unknown from deposits older than upper Oligocene. Thus, a late Oligocene age is suggested on the basis of palynomorph data for Core 5, which includes a radiolarian assemblage of the Cyrtocapsa tetrapera Zone of early Miocene age. Section 6-3 may be assigned a tentative Oligocene age on the evidence of $T$. succincta, presently known from Oligocene sediments, and $C$. cf. $C$. reticulosum, whose type was described from middle to upper Oligocene sediments. A late Oligocene age is suggested for this core by the presence of the radiolarian zone $L$. elongata and the abundance of Stictodiscus gelidus, a diatom previously studied alongside such silicoflagellates as Rocella gemma. Core 7 contains no stratigraphically significant palynomorphs, and Cores 8 and 9 contain an assemblage which indicates an Oligocene age. The occurrence of Phthanoperidinium eocenicum may indicate a late Eocene age for Core 10, which is barren of any other microfossils. Core 11 contains no palynomorphs.

\section{SEDIMENT ACCUMULATION RATES}

Figure 14 summarizes the history of sediment accumulation at Site 358. Age control in the upper 700 meters is rather poor, because of spot coring (with intervals of 60 to $70 \mathrm{~m}$ ), the absence of calcareous microfossils (present water depth is $4990 \mathrm{~m}$ ), and only mixed high- and mid-latitude radiolarian and silicoflagellate assemblages are present. Cores 9 and 10 contain only pyritized, non-age-diagnostic radiolarians and palynomorphs. We used calcareous nannofossils for age assignments in the predominantly calcareous middle Eocene to upper Cretaceous sequence from 730 meters to the bottom of the hole at about 840 meters.

During late Campanian-early Maestrichtian times, accumulation of the red clays and marly chalks probably took place at about $1 \mathrm{~cm} / 1000$ years, first above and then below the CCD. From the midMaestrichtian to about the mid-Danian, accumulation of red clays alone proceeded at a slow rate, about 0.1 to $0.3 \mathrm{~cm} / 1000$ years. The accumulation rate was about the same or only slightly higher when the site again lay above the CCD, and coccoliths and benthic (but no planktonic) foraminifers were deposited during the remainder of the Danian and early late Paleocene. From our data we cannot conclude whether or not the uppermost Paleocene and lowermost Eocene are present. If they are present in the interval of about 20 meters between Cores 12 and 13, they would also have 


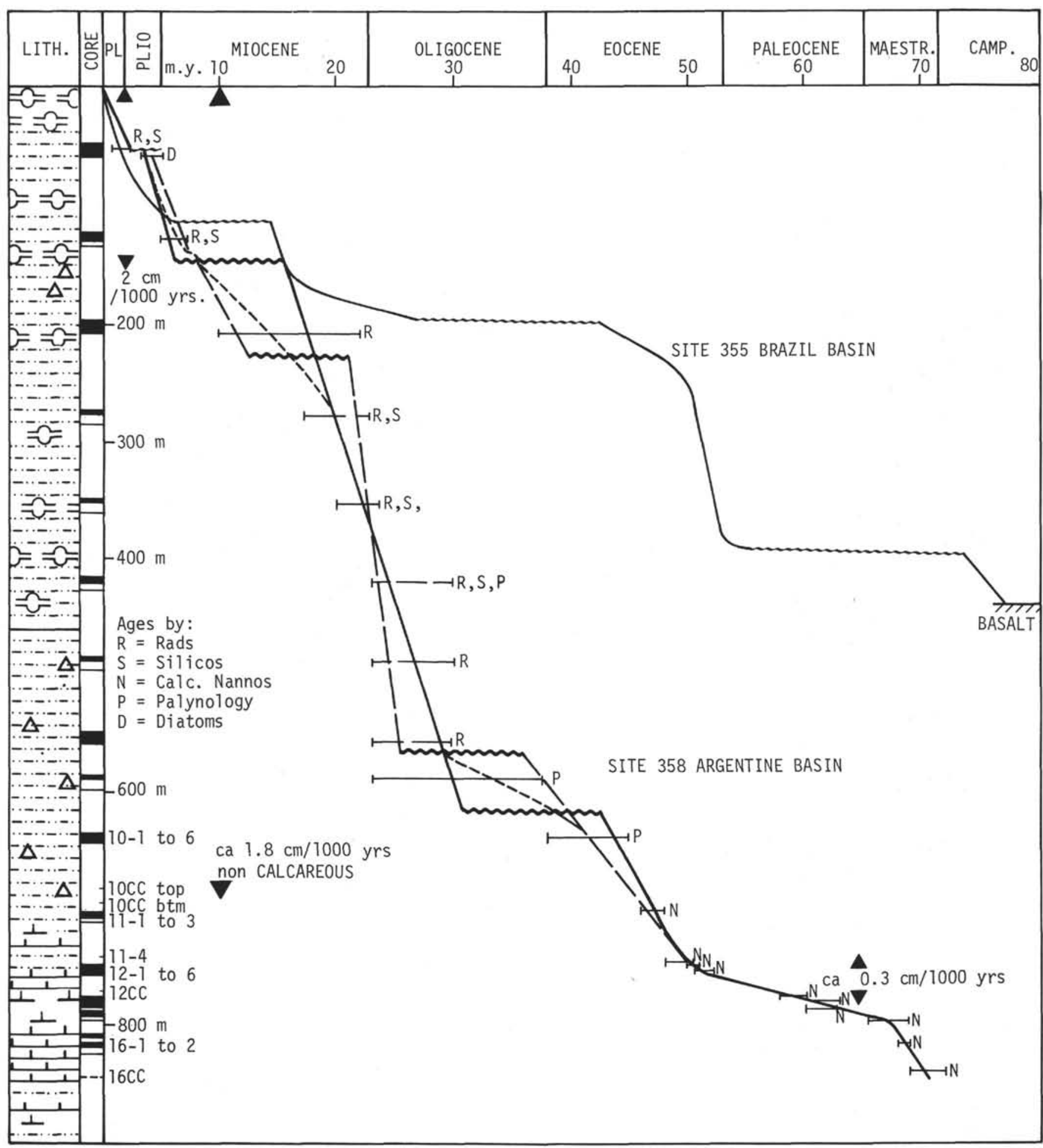

Figure 14. Sediment accumulation history, Site 358. See text for explanation of alternative curves.

deposited at a rate of about $0.3 \mathrm{~cm} / 1000$ years. A hiatus in this part of the sequence cannot be excluded, however. Accumulation was still slow during the later part of the early Eocene, and perhaps increased to about $1 \mathrm{~cm} / 1000$ years, toward the middle Eocene, when both calcareous nannofossils and planktonic foraminifers were preserved. Horizon B occurs at the depth where the accumulation rate changes from very low to about $1 \mathrm{~cm} / 1000$ years in the lower Eocene, the level of transition from calcareous to noncalcareous sediments. Core 11, the youngest core containing calcareous microfossils (except for infrequent planktonic foraminifers in Core 7), consists of two different lithologies. Sections 1, 2, and the upper part of 3 
contain noncalcareous ferruginous mudstones; the rest of Section 3 and Section 4 contain much harder, marly chalks. We take the contact of the two lithologies in Core 11 to be a drilling artifact. We suggest that the upper part of the core was taken, as intended, at the top of cored interval 11, but the bottom part of the core was recovered well below this level, probably midway between the Core 11 and 12 intervals. In this case, the accumulation rate in the Eocene would have remained the same at least until the middle Eocene (see Figure 14). Accumulation may have been continuous (but of noncalcareous material) from then until the Pleistocene, or interrupted by one, two, or more hiatuses (Figure 14). The hiatuses were chosen as representing about the same times as in the Brazil Basin, Site 355 .

The core-catcher sample of Core 10 contains three distinct lithologies. The bottom part consists of red clay probably picked up near the top of Core 11 , at the bottom of the interval drilled with the core barrel of Core 10 in place. The middle part of Sample 10, CC consists of a dark gray to black mudstone; the top part is the blue-gray siliceous mudstone that is in the core itself. The dark gray mudstone, like the red clay, was probably recovered considerably below the rest of Core 10.

Whichever version of the Eocene-early Oligocene sedimentary history of this site we favor, our data strongly suggest that accumulation was rapid during the late Oligocene and the early Miocene. The regional reflector Horizon A is late Oligocene in age, and seems to represent a diagenetic change in the siliceous constituents rather than a change in accumulation rate or a hiatus. The presence or absence of mid-Miocene sediments cannot be established beyond doubt with our data. Accumulation rate of sediments seems to have been fairly constant at about $2 \mathrm{~cm} / 1000$ years, from the late Miocene to the present. A minor hiatus is, however, indicated in Core 1; diatom remains suggest an early Pliocene to Miocene age below Section 4, and a late Pleistocene age for the upper part of the sequence (Fenner, this volume). Again, it cannot be proven that this hiatus is not a drilling artifact.

\section{CORRELATION OF REFLECTION PROFILE WITH DRILLING RESULTS}

The reference profile for Site 358 (L-DGO profile V31-01, \#119) showed approximately $1.0 \mathrm{sec}$ of sediment overlying acoustic basement(Figure 3). Two intermediate reflectors-one at about the middle of the sediment column, another slightly above acoustic basement-are also clearly visible on the reference profile.

The approach profile shows an upper transparent zone $(0.58 \mathrm{sec}$ thick $)$, an upper reflective zone $(0.58 \mathrm{sec}-$ $0.69 \mathrm{sec})$, a lower transparent zone $(0.69 \mathrm{sec}-0.88 \mathrm{sec})$, a lower reflective zone $(0.88 \mathrm{sec}-0.98 \mathrm{sec})$, and the acoustic basement at $1.04 \mathrm{sec}$. Another discontinuous reflector occurs in the area at a depth of $0.20 \mathrm{sec}$. We saw this reflector on the approach profile soon after we arrived at the turning point enroute to Site 358 (see Figure 15), but this reflector vanishes immediately at Site 358 .
Sonic velocities measured in the cores allow us to estimate thicknesses of the reflective and transparent zones observed on the seismic profile. We have used the following interval velocities here: $1.55 \mathrm{~km} / \mathrm{sec}$ from ocean bottom to $0.20 \mathrm{sec}, 1.6 \mathrm{~km} / \mathrm{sec}$ between 0.20 to $0.58 \mathrm{sec}, 1.8 \mathrm{~km} / \mathrm{sec}$ between 0.58 and $0.69 \mathrm{sec}, 1.8$ $\mathrm{km} / \mathrm{sec}$ from 0.69 to $0.88 \mathrm{sec}, 2.1 \mathrm{~km} / \mathrm{sec}$ from 0.88 to $0.98 \mathrm{sec}$, and $2.1 \mathrm{~km} / \mathrm{sec}$ from 0.98 to $1.04 \mathrm{sec}$.

On the basis of these velocities, the following subbottom depths to various horizons can be calculated: 155 meters for the uppermost reflector at $0.20 \mathrm{sec}, 459$ meters for the top of the upper reflective zone, 729 meters for the top of the lower reflective zone, and 897 meters for the acoustic basement. Unfortunately, the hole had to be terminated at 842 meters because of adverse weather conditions.

The reflector at 155 meters seems to correlate with a possible hiatus and/or a possible change in accumulation rate between Cores 2 and 3 . Core 2 is diatomradiolarian mud, whereas Core 3 is siliceous mud in which the biogenic silica has been transformed into amorphous silica. We assume that the uppermost reflector $(155 \mathrm{~m})$ corresponds to the zone of transition from Unit $1 \mathrm{~A}$ to Unit $1 \mathrm{~B}$; i.e., from diatom-radiolarian mud to siliceous mud. From its depth in the section, we think that this reflector is reflector $\mathrm{F}$ of Ewing and Lonardi (1971).

A similar change from diatom-radiolarian mud to siliceous mud occurs between Cores 6 and 7. The calculated depth of the top of the upper reflective zone $(459 \mathrm{~m})$ falls between Cores 6 and 7 . We think that the top of the upper reflective zone marks a diagenetic transition similar to that between Cores 2 and 3 . Accordingly, we place the boundary at 459 meters, between Units $1 \mathrm{C}$ (diatom-radiolarian mudstone) and 1D (siliceous mudstone). A sudden decrease in drilling rate at 450 meters also marks the transition.

Even though the upper reflective zone is discontinuous in the vicinity of Site 358 , it is the most prominent intermediate reflector of the section. Its prominence and subsurface depth of approximately $7.25 \mathrm{sec}$ (see Figure 15) suggest that it is probably reflector A of Ewing and Lonardi (1971). So at least in the northeastern sector of the Argentine Basin, reflector A is late Oligocene in age and marks a diagenetic transition. The bottom of the upper reflective zone at 558 meters probably marks the complete disappearance of biogenic silica. Cores 9 and 10 of Unit 1 B contain no siliceous fossils. The transition from the upper reflective zone to the lower transparent zone is gradational, probably because the transition from biogenic silica to recrystallized silica within Unit $1 D$ is also gradational.

The top of the lower reflective zone at 729 meters correlates with the contact of noncalcareous and calcareous sediments in Core 11 at this depth. Since we can assign no age to the noncalcareous upper part of Core 11 , the top of this reflective zone may also correspond to a possible major hiatus spanning the rest of the middle and the lower upper Eocene, or to a sequence of very slow accumulation (see Figure 13) over the same interval. We assume the transition from 

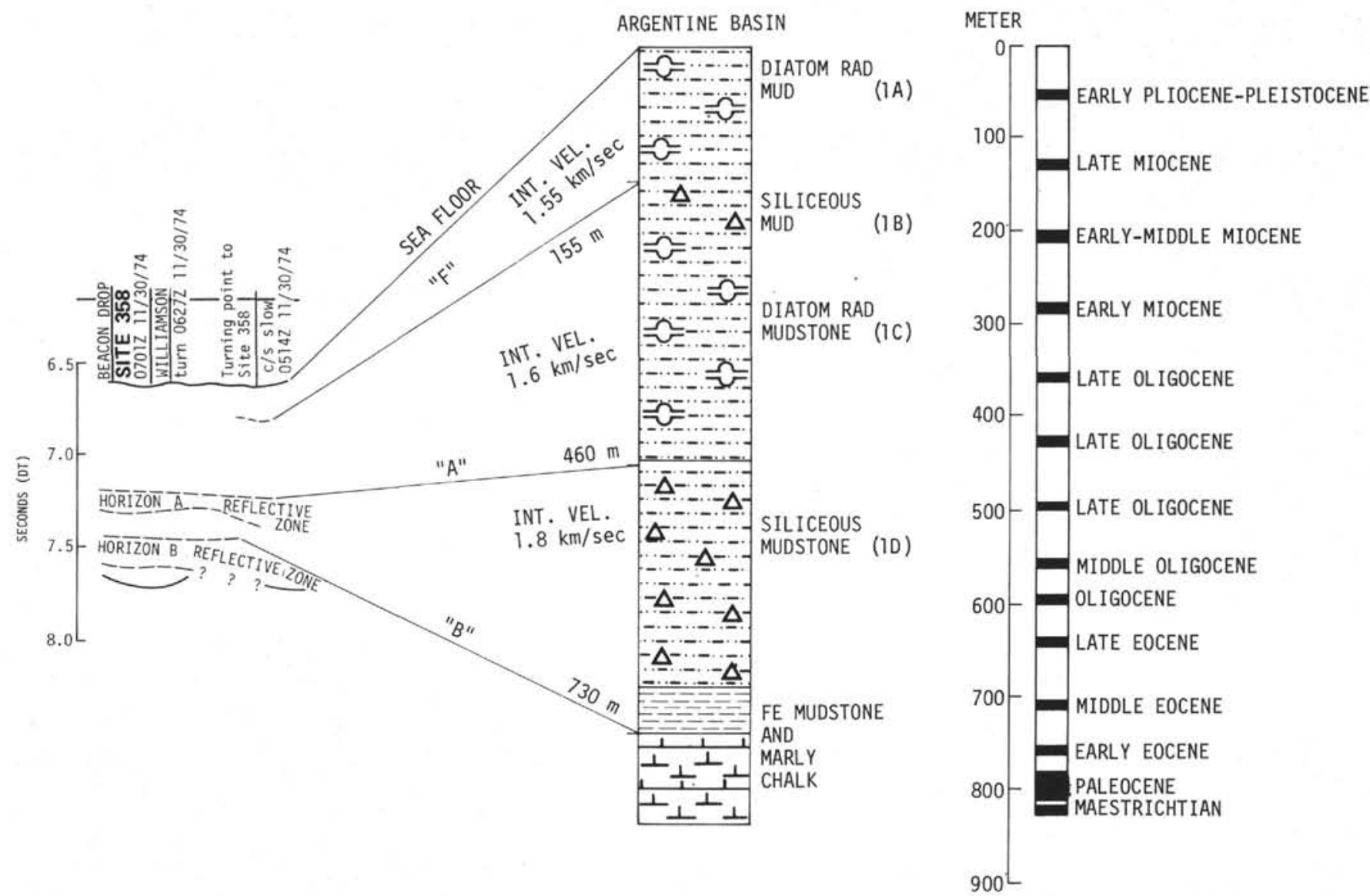

Figure 15. Correlation of the Site 358 approach profile with the lithostratigraphic interval drilled.

Unit $1 \mathrm{E}$ to 2 to lie at 730 meters. Because it is discontinuous, filling the low areas between basement highs, we correlate the top of the lower reflective zone with reflector B of Ewing and Lonardi (1971). The bottom of the lower reflective zone, at a calculated depth of 834 meters, may correlate with the transition from marly chalk, deposited near the CCD, to chalk with well-preserved calcareous microfossils, as recovered from the bottom of the core catcher of Core 16. The acoustic basement, at a calculated depth of 897 meters, was not reached.

\section{SUMMARY AND CONCLUSIONS}

We did not achieve one of the primary objectives at Site 358 , the dating of basaltic basement between anomalies 32 and 33 , because bad weather forced us to terminate the hole early. It is possible to estimate basement age, however, if certain assumptions are made. The calculated depth to basement (see earlier discussion) is 897 meters, or 70 meters below the bottom of Core 16, dated as latest Campanian or earliest Maestrichtian, or about 70 m.y.B.P., according to van Hinte (1976). The accumulation rate for the Upper Cretaceous sequence at Site 358 is about 17 $\mathrm{m} / \mathrm{m}$.y. Assuming accumulation was constant (i.e., no hiatus between basement and Core 16) and proceeded at this average rate, and assuming acoustic basement here is true basement and not a sill, the basement age would be about 74 m.y.B.P., or mid-Campanian.
The isostatically adjusted depth of basement at Site 358 and basement age of 74 m.y.B.P. define a point which falls almost exactly on the empirical elevation curve defined by Sclater and Detrick (1973) from the North Pacific and generally typical of all ocean basins.

The last up-hole occurrence of calcium carbonate sediments is at 730 meters, in a middle Eocene deposit. If we assume that this represents the time at which the deposition site subsided below the CCD, 30 m.y. of subsidence at a normal rate would put the CCD at 4200 meters in the middle Eocene; this agrees reasonably well with the approximately 3700 -meter CCD cited for this time by Berger and von Rad (1972). Alteration of muds and chalks in Unit 2 is difficult to explain. It may be a consequence of the site's proximity to the CCD during most of the period from the early Maestrichtian to the middle Eocene (see discussion in Premoli-Silva and Boersma, this volume). The site was subsiding rapidly during this period, with a concomitant general downward movement of the CCD. Although the tendency is toward such a trend (see Figure 4, van Andel, 1975), data are insufficient to draw a final conclusion.

The sharp facies change in the middle Eocene-from marls and mudstones to siliceous and biosiliceous mudstones of unknown age (but older than latest Eocene)-indicates environmental changes. If subsidence below the CCD were the only active process, we should expect a drop in the rate of deposition. This is 
one possible interpretation of the sedimentation history between Cores 8 and 11 (small dashed line in Figure 14). A continued high sedimentation rate into the late Eocene (solid line case in Figure 14), with a hiatus at the Eocene-Oligocene boundary and well into the Oligocene, is, however, equally plausible-indeed expected in the Argentine Basin since an EoceneOligocene boundary hiatus occurs at Sites 354, 355, 356,357 , and 359 , and since this hiatus is probably a result of bottom current intensification. Thus the exact transition from carbonate to non-carbonate sedimentation may have been affected by current erosion or current-controlled dissolution as well as a CCD effect, indicating that there may have been a carbonate sequence as young as late Eocene deposited and then subsequently removed.

Figure 14 shows a sudden increase in the deposition rate, marking an increase in biosiliceous productivity, in the late Oligocene.

We follow Frakes and Kemp (1973) in favoring a climatic reconstruction for the Antaractic which allows a limited amount of regional ice formation in the Eocene (Geitzenauer et al., 1968). Savin et al. (1975) show a rapid drop of $5^{\circ} \mathrm{C}$ in bottom temperatures of the world oceans at about 43 m.y.B.P., or latest middle to earliest late Eocene (Zones P14 and P15 of Berggren and Van Couvering, 1973). Kennett and Shackleton (1976), using oxygen isotopic analysis of Subantarctic South Pacific cores, report this same bottom temperature drop, but report the sharp temperature change to have occurred in earliest Oligocene (38 m.y.B.P.) in the Subantarctic and latest Eocene in the tropical Pacific. Presumably these temperature drops reflect the first intruduction of cold deep water masses from the south into the meridional basins. This cold bottom water, formed at high southern latitudes, is here termed "pre-Antarctic Bottom Water" (pre-AABW). Pre-AABW, with a temperature of $3^{\circ}-5^{\circ} \mathrm{C}$ (from Frakes and .Kemp, 1973; Shackleton and Kennett, 1975; Savin et al., 1975), probably circulated in a manner similar to that of present-day Antarctic Bottom Water (AABW), but more sluggishly. This late Eocene formation of bottom water (pre-AABW) is probably one of the most significant oceanographic events of the Cenozoic, and was enhanced during the Oligocene with the formation of the circum-Antarctic current in the middle to late Oligocene (Kennett et al., 1975) and concomitant extension of the southern ice.

Water as dense as the present AABW cannot form under any but the most severe climatic isolation conditions, those allowing winter formation of abundant sea ice. These conditions probably began with true thermal isolation of the high southern latitude regions by formation of a truly circum-Antarctic current. On the basis of a sharp drop in bottom paleotemperatures, Savin et al. (1975) speculate that this did not occur until the beginning of the middle Miocene, at which time the Drake Passage opened (i.e., later than the opening cited by Kennett et al., 1975, above).

Note that the siliceous diagenetic mudstones of subunit $1 \mathrm{D}$ cover the late Eocene-early Oligocene period of sharp bottom temperature drop associated with establishment of pre-AABW circulation. The top of this diagenetic sequence correlates with the Horizon A reflector at this site. Similarly, the siliceous diagenetic mud of sub-unit $1 \mathrm{~B}$ covers the mid-Miocene period of sharp temperature drop perhaps associated with the establishment of circulation of true AABW. The top of this diagenetic sequence correlates with the Horizon F reflector at this site. The diagenetic process altering biogenic silica to silica cement may be favored by increased current activity (see discussion in Supko and Perch-Nielsen, this volume).

\section{REFERENCES}

Amaral, G., Cordani, U., Kawashita, K., and Reynolds, J., 1966. K-AR dates of basaltic rocks from southern Brazil: Geochim. Cosmochim. Acta, v. 30, p. 159.

Berger, W. and von Rad, U., 1972. Cretaceous and Cenozoic sediments from the Atlantic Ocean: In Hayes D.E., Pimm, A.C., et. al., Initial Reports of the Deep Sea Drilling Project, Volume 14: Washington (U.S. Government Printing Office), p. 787-953.

Berggren, W.A. and Hollister, C.D., 1974. Paleogeography, paleobiogeography and the history of circulation in the Atlantic Ocean: In Hay, W.W. (Ed.), Studies in paleooceanography: Spec. Publ. 20, Soc. Econ. Paleontol. Mineral., p. 126-186.

Berggren, W.A. and Van Couvering, J.A., 1973. Late Neogene chronostratigraphy, biostratigraphy, and paleoclimatology: Woods Hole Oceanographic Institute Tech. Rep. WHOI-73-40.

Boström, K. and Peterson, M.N.A., 1966. Precipitates from hydrothermal exhalations on the East Pacific Rise: Econ. Geol., v. 61, p. 1258.

Boström, K., Peterson, M.N.A., Joensuu, O., and Fischer, D.E., 1969. Aluminum poor ferromanganoan sediments on active oceanic ridges: J. Geophys. Res., v. 74, p. 3261.

Burckle, L.H. and Stanton, D., 1974. Distribution of displaced Antarctic diatoms in the Argentine Basin. In Simonsen, R. (Ed.), Third Symp. Recent and fossil marine diatoms, Kiel, 1975, Proc.

Chen, P., 1975. Antarctic Radiolaria. In Hayes, D.E., and Frakes, L.A., et al., Initial Reports of the Deep Sea Drilling Project, Volume 28: Washington (U.S. Government Printing Office), p. 437-513.

Ewing, M. and Lonardi, A.G., 1971. Sediment transport and distribution in the Argentine Basin. 5. Sedimentary structure of the Argentine Margin, Basin and related provinces. In Ahrens, L. H. et al., (Eds.), Physics and chemistry of the earth, v. 5: New York (Pergamon Press).

Ewing, M., Eittreim, S..L., Ewing, J..I., and Le Pichon, X., 1971. Sediment transport and distribution in the Argentine Basin, 3, Nepheloid layer and processes of sedimentation. In Ahrens, L.H. et al. (Eds.), Physics and chemistry of the earth, v. 8: New York (Pergamon Press), p. 49.

Frakes, L.A. and Kemp, E.M., 1973. Paleogene continental positions and evolution of climate. In Tarling, D.H. and Runcorn, S.K. (Eds.), Implications of Continental Drift to the earth sciences, v. 1; New York (Academic Press), p. 535 .

Geitzenauer, K.R., Margolis, S.B., and Edwards, D.S., 1968. Evidence consistent with Eocene glaciation in a South Pacific deep sea sedimentary core: Earth Planet Sci. Lett., v. 4 , p. 173 .

Groot, J.J., Groot, C.R., Ewing, M., Burckle, L., and Conolly, G.R., 1967. Spores, pollen, diatoms, and 
provenance of the Argentine Basin sediments. In Sears, M. (Ed.), Progress in oceanography, v. 4: London (Pergamon Press), p. 179-217.

Heirtzler, J.R., Dickson, G.O., Herron, E.M., Pitman, W.C. III and Le Pichon, X., 1968. Marine magnetic anomalies, geomagnetic field reversals, and motions of the ocean floor and continents: J. Geophys. Res., v. 73, p. 2119-2136.

Kennett, J.P. and Shackleton, N.J., 1976. Osygen isotopic evidence for the development of the psychrosphere $38 \mathrm{~m} . \mathrm{y}$. ago: Nature, v. 260. p. 513-515.

Kennett, J.P., Houtz, R.E., et. al., 1975. Cenozoic paleooceanography in the southwest Pacific Ocean, Antarctic glaciation, and the development of the Circum-Antarctic Current. In Kennett, J.P., Houtz, R.E., et al., Initial Reports of the Deep Sea Drilling Project, Volume 29: Washington (U.S. Government Printing Office), p. 1155.

Maxwell, A.E., Von Herzen, R.P., et al., 1970. Initial Reports of the Deep Sea Drilling Project, Volume 3: Washington (U.S. Government Printing Office).

McCollum, D.W., 1975. Diatom stratigraphy of the Southern Ocean. In Hayes, D.E., Frakes, L.A., et al., Initial Reports of the Deep Sea Drilling Project, Volume 28: Washington (U.S. Government Printing Office), p. 515-571.

Perch-Nielsen, K., 1975. Late Cretaceous to Pleistocene silicoflagellates from the southern southwest Pacific, DSDP Leg 29. In Kennett, J.P., Houtz, R.E., et al., Initial Reports of the Deep Sea Drilling Project, Volume 29: Washington (U.S. Government Printing Office), p. 873908.

Savin, S.M., Douglas, R.G., and Stehli, F.G., 1975. Tertiary marine paleotemperatures; Geol. Soc. Am. Bull., v. 86, p. $1499-1510$.
Sclater, J.G. and Detrick, R., 1973. Elevation of mid-ocean ridges and the basement age of JOIDES Deep Sea Drilling Sites: Geol. Soc. Am. Bull., v. 84, p. 1547-1554.

Shackleton, N.J. and Kennett, J.P., 1975. Paleotemperature history of the Cenozoic and the initiation of Antarctic glaciation: oxygen and carbon isotope analyses in DSDP Sites 277, 279 and 281. In Kennett, J.P., Houtz, R.E., et al., Initial Reports of the Deep Sea Drilling Project, Volume 29: Washington (U.S. Government Printing Office), p. 743.

Siedman, G. and Miller, J., 1968. K-Ar determinations on basaltic rocks from southwest Africa and their bearing on continental drift: Earth Planet. Sci. Lett., v. 4, p. 451.

van Andel, T.H., 1975. Mesozoic/Cenozoic calcite compensation depth and the global distribution of calcareous sediments: Earth Planet. Sci. Lett., v. 16, p. 187-194.

van Hinte, J.E., 1976. A Cretaceous time scale. Am. Assoc. Petrol. Geol. Bull., v. 60, p. 498-516.

von der Borch, C.C.and Rex, R.W., 1970. Amorphous iron oxide precipitates in sediment cored during Leg 5, DSDP. In McManus, D.A., Burns, R.G., et al., Initial Reports of the Deep Sea Drilling Project, Volume 5: Washington (U.S. Government Printing Office), p. 541-544.

von der Borch, C.E., Nesteroff, W.D., and Galehouse, J.S., 1971. Iron rich sediments cored during Leg 8 of the DSDP. In Tracey, J., et al., Initial Reports of the Deep Sea Drilling Project, Volume 8: Washington (U.S. Government Printing Office), p. 541.

Wüst, G., 1957. Stromgeschwindigkeiten und Strommengen in den Tiefen des Atlantischen Ozeans: Wiss. Ergeb. Deutschen Atlantischen Expedition "Meteor" 1927-1927, v. 6 , p. 261 . 


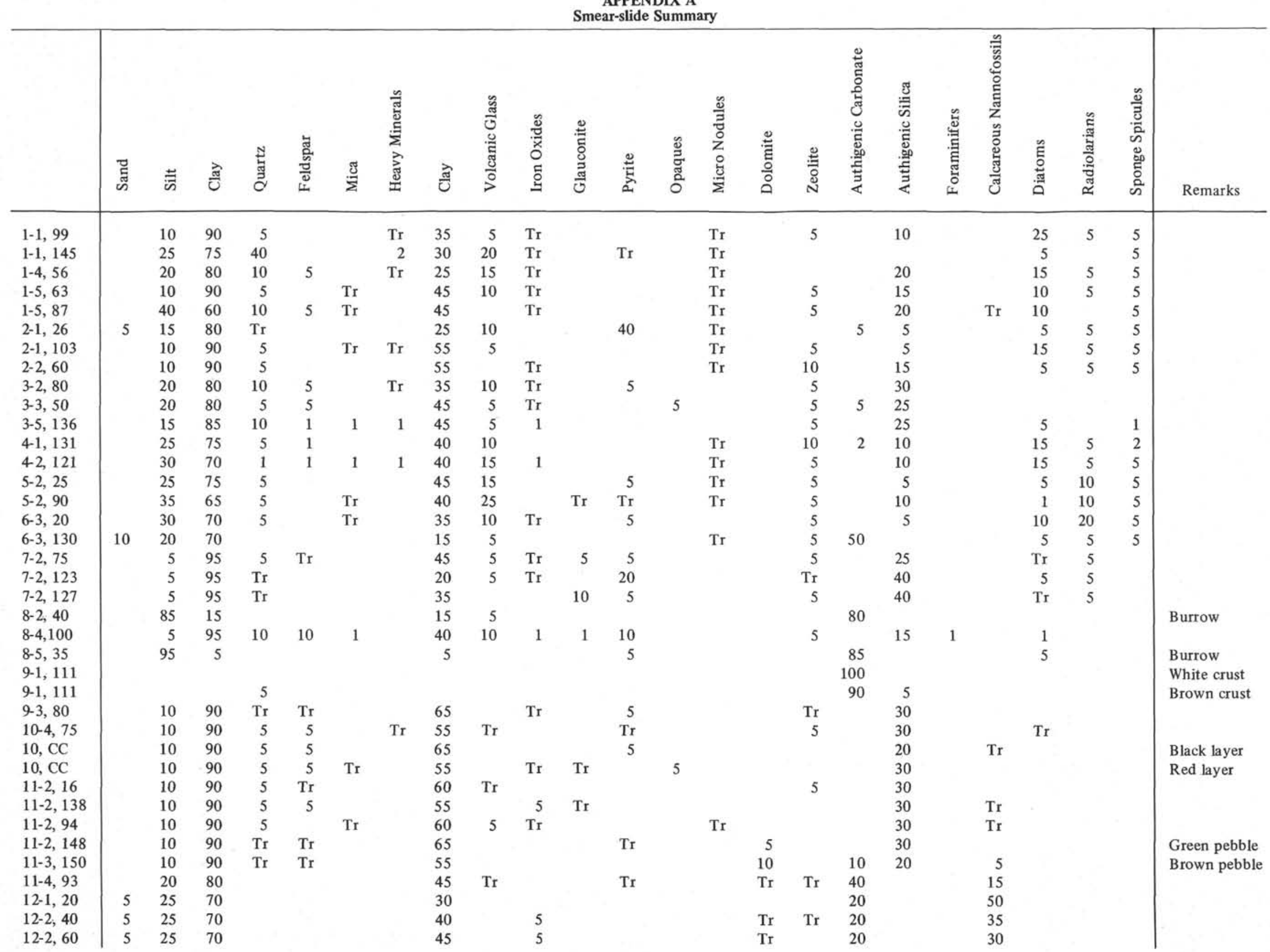


APPENDIX B

Carbonate and Quartz Determinations

\begin{tabular}{|c|c|c|c|c|c|}
\hline Section & $\begin{array}{c}\text { Sediment } \\
\text { Depth }(\mathrm{cm})\end{array}$ & $\mathrm{CaCO}_{3}(\%)$ & Org (\%) & $\begin{array}{c}\text { Total } \\
\text { Carb }(\%)\end{array}$ & Qtz (\%) \\
\hline $1-5$ & 5428 & 0.11 & 0.20 & 0.22 & \\
\hline $1-5$ & 5446 & 0.85 & 0.38 & 0.49 & 10.75 \\
\hline $1-6$ & 5582 & 0.00 & 0.48 & & \\
\hline $1-6$ & 5600 & 0.82 & 0.21 & 0.31 & 10.12 \\
\hline $2-2$ & 12540 & 0.03 & 0.21 & 0.21 & \\
\hline $2-3$ & 12760 & 1.17 & 0.12 & 0.27 & 10.64 \\
\hline $2-4$ & 12894 & 0.00 & 0.45 & & \\
\hline $3-2$ & 20168 & & & & \\
\hline $3-2$ & 20193 & 0.27 & 0.26 & 0.29 & \\
\hline $3-2$ & 20201 & 0.60 & 0.13 & 0.21 & 9.40 \\
\hline $3-5$ & 20618 & & & & \\
\hline $3-5$ & 20640 & 0.37 & 0.09 & 0.13 & \\
\hline $3-5$ & 20643 & 0.20 & 0.05 & 0.08 & 9.78 \\
\hline $4-1$ & 27648 & 0.0 & & & \\
\hline $4-1$ & 27662 & 0.50 & 0.21 & 0.27 & \\
\hline $4-1$ & 27687 & 0.64 & 0.24 & 0.32 & 7.84 \\
\hline $5-1$ & 35206 & 0.0 & & & \\
\hline $5-2$ & 35337 & 1.10 & 0.12 & 0.25 & \\
\hline $5-2$ & 35392 & 0.47 & 0.16 & 0.22 & 9.37 \\
\hline $6-1$ & 41819 & 0.30 & 0.16 & 0.19 & \\
\hline 6-3 & 42133 & 0.71 & 0.22 & 0.30 & 7.73 \\
\hline $6-3$ & 42171 & & & & \\
\hline $7-1$ & 49019 & & & & \\
\hline $7-1$ & 49080 & 0.20 & 0.18 & 0.20 & \\
\hline $7-2$ & 49237 & 0.56 & 0.16 & 0.23 & 9.85 \\
\hline $8-1$ & 55212 & & & & \\
\hline $8-2$ & 55276 & 4.08 & 0.17 & 0.66 & \\
\hline $8-2$ & 55279 & 0.52 & 0.27 & 0.34 & 9.89 \\
\hline $9-2$ & 59114 & 0.40 & 0.12 & 0.17 & \\
\hline $9-3$ & 59229 & 0.48 & 0.20 & 0.26 & 18.39 \\
\hline $10-4$ & 64170 & 0.10 & 0.23 & 0.24 & \\
\hline $10-4$ & 68769 & 0.36 & 0.21 & 0.25 & 20.75 \\
\hline $11-2$ & 70516 & 0.00 & 0.04 & 0.08 & \\
\hline $11-3$ & 70609 & & & & \\
\hline $11-4$ & 70755 & 47.77 & 0.05 & 5.79 & \\
\hline $11-4$ & 70832 & & & & \\
\hline $11-4$ & 70846 & 51.82 & 0.29 & 6.51 & 13.07 \\
\hline $12-3$ & 75426 & 63.33 & 0.24 & 7.84 & 29.16 \\
\hline $12-3$ & 75430 & 68.97 & 0.04 & 8.32 & \\
\hline $12-5$ & 75754 & 36.65 & 0.06 & 4.46 & \\
\hline $12-5$ & 75760 & 38.05 & 0.23 & 4.80 & 13.60 \\
\hline $13-1$ & 77978 & 21.99 & 0.21 & 2.85 & 8.86 \\
\hline $13-1$ & 78036 & 29.58 & 0.06 & 2.61 & \\
\hline $13-4$ & 78455 & 22.01 & 0.45 & & \\
\hline 141 & 78872 & 45.03 & 0.18 & 5.58 & 11.86 \\
\hline 141 & 78872 & 51.27 & 0.07 & 6.23 & \\
\hline 142 & 79038 & 40.02 & 0.30 & & \\
\hline 142 & 79135 & 28.54 & 0.37 & 3.79 & 10.21 \\
\hline 144 & 79440 & 47.11 & 0.05 & 5.71 & \\
\hline $15-1$ & 79865 & 1.75 & 0.36 & & \\
\hline $15-1$ & 79870 & 0.43 & 0.00 & 0.06 & 12.58 \\
\hline $15-1$ & 79870 & 0.13 & 0.04 & 0.06 & \\
\hline $15-2$ & 80090 & 21.74 & 0.05 & 2.66 & \\
\hline $16-2$ & 81948 & 13.51 & 0.20 & 1.83 & 14.01 \\
\hline $16-2$ & 81951 & 10.26 & 0.33 & & \\
\hline $16-2$ & 81956 & 16.72 & 0.05 & 2.06 & \\
\hline
\end{tabular}




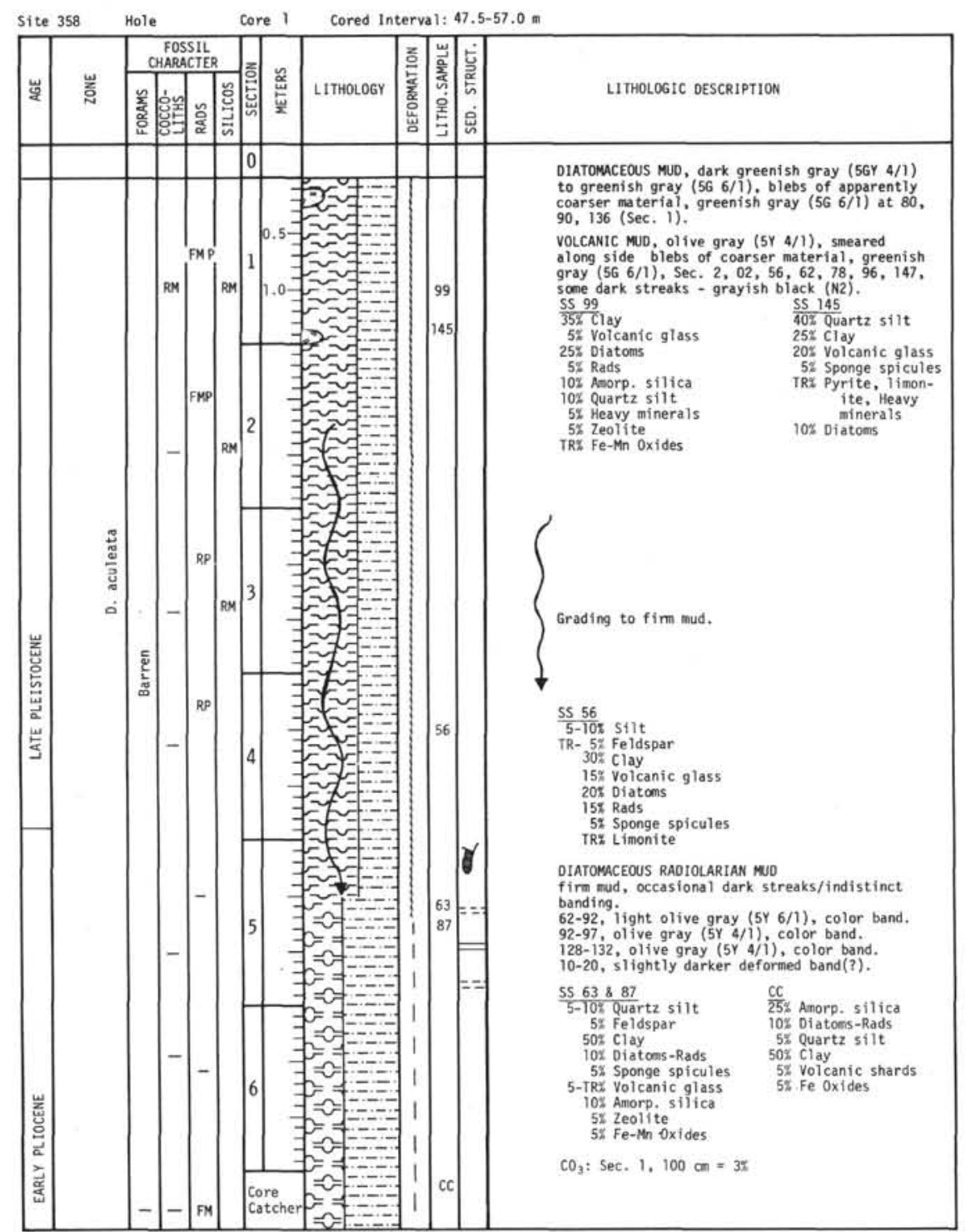

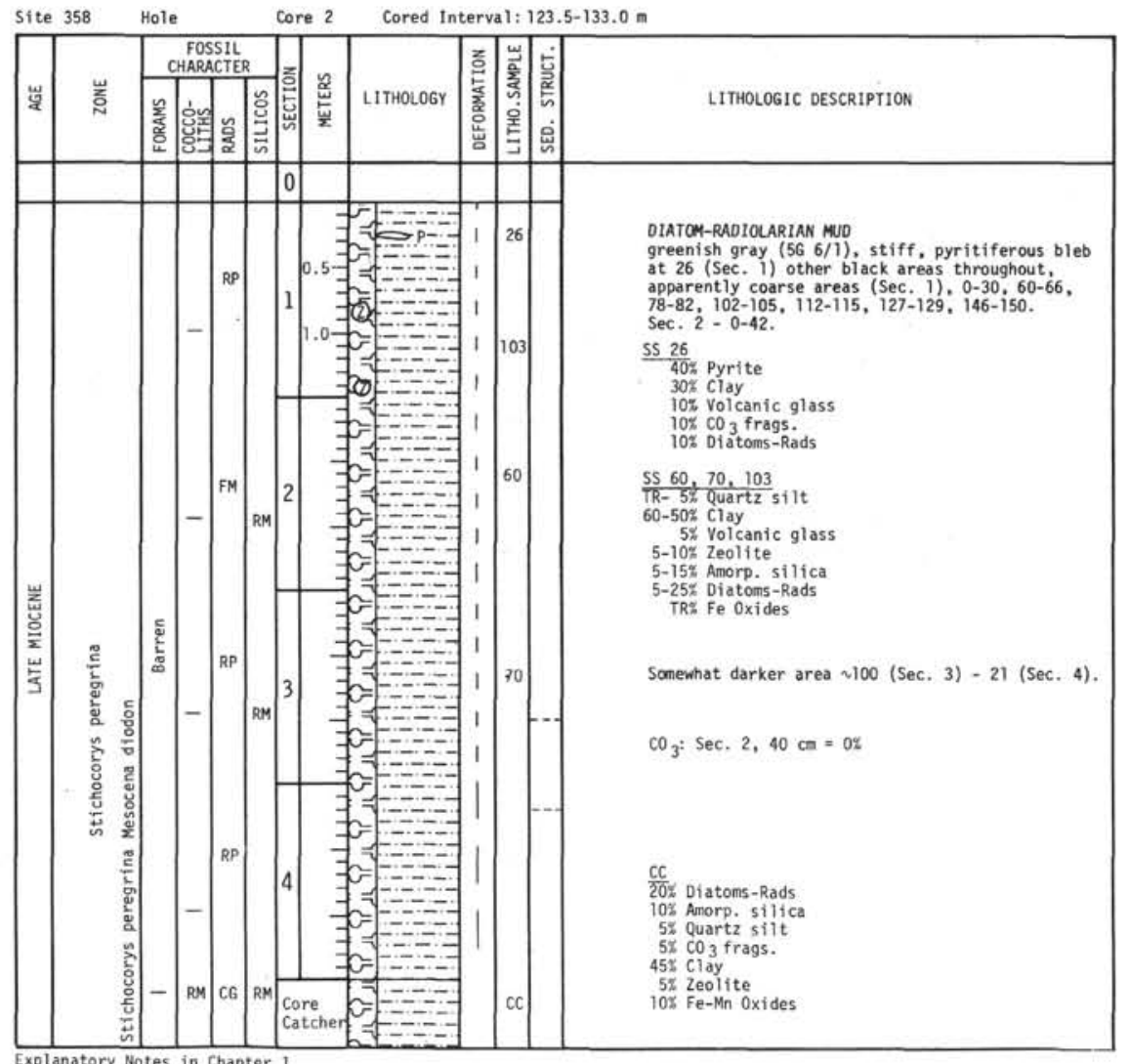




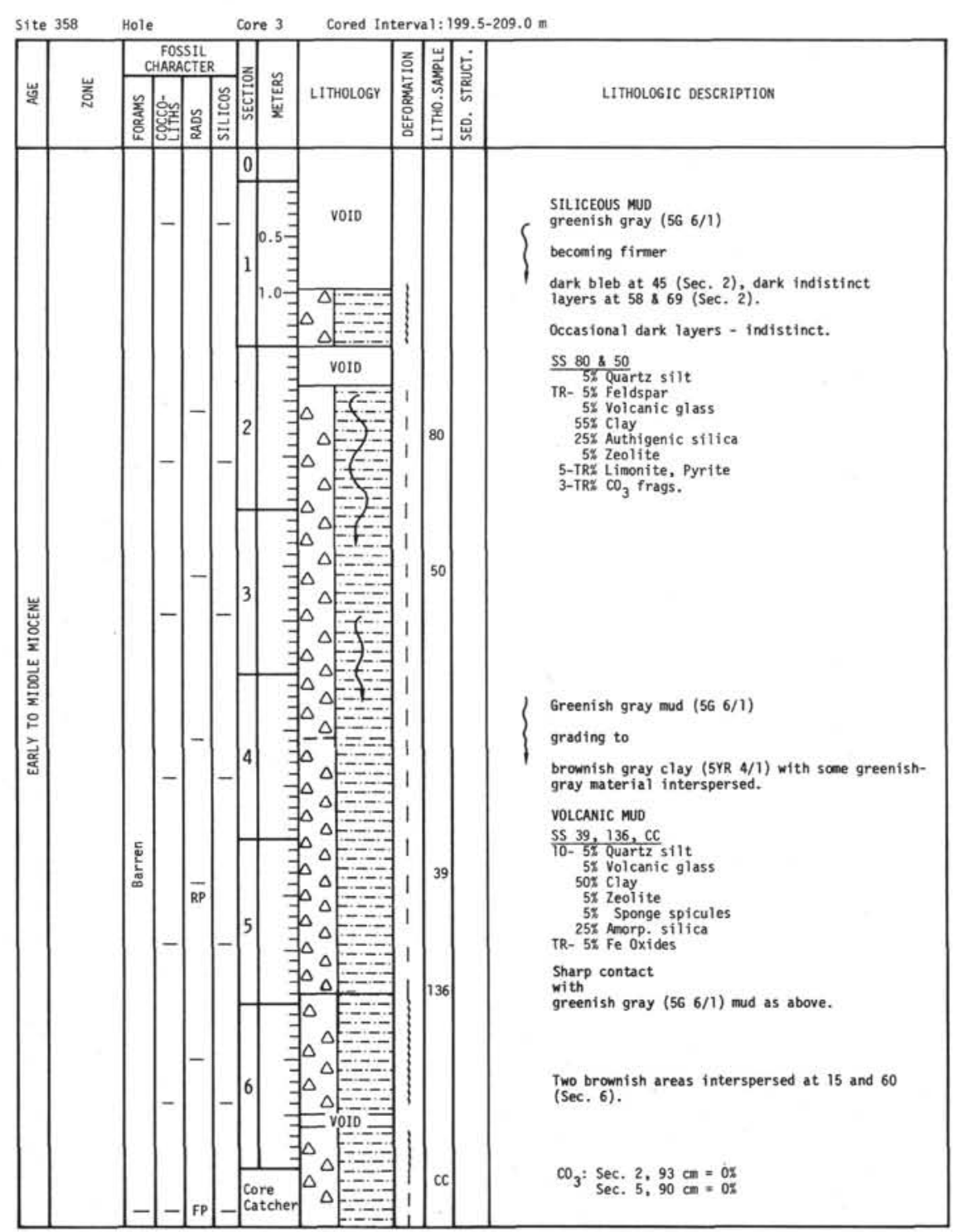

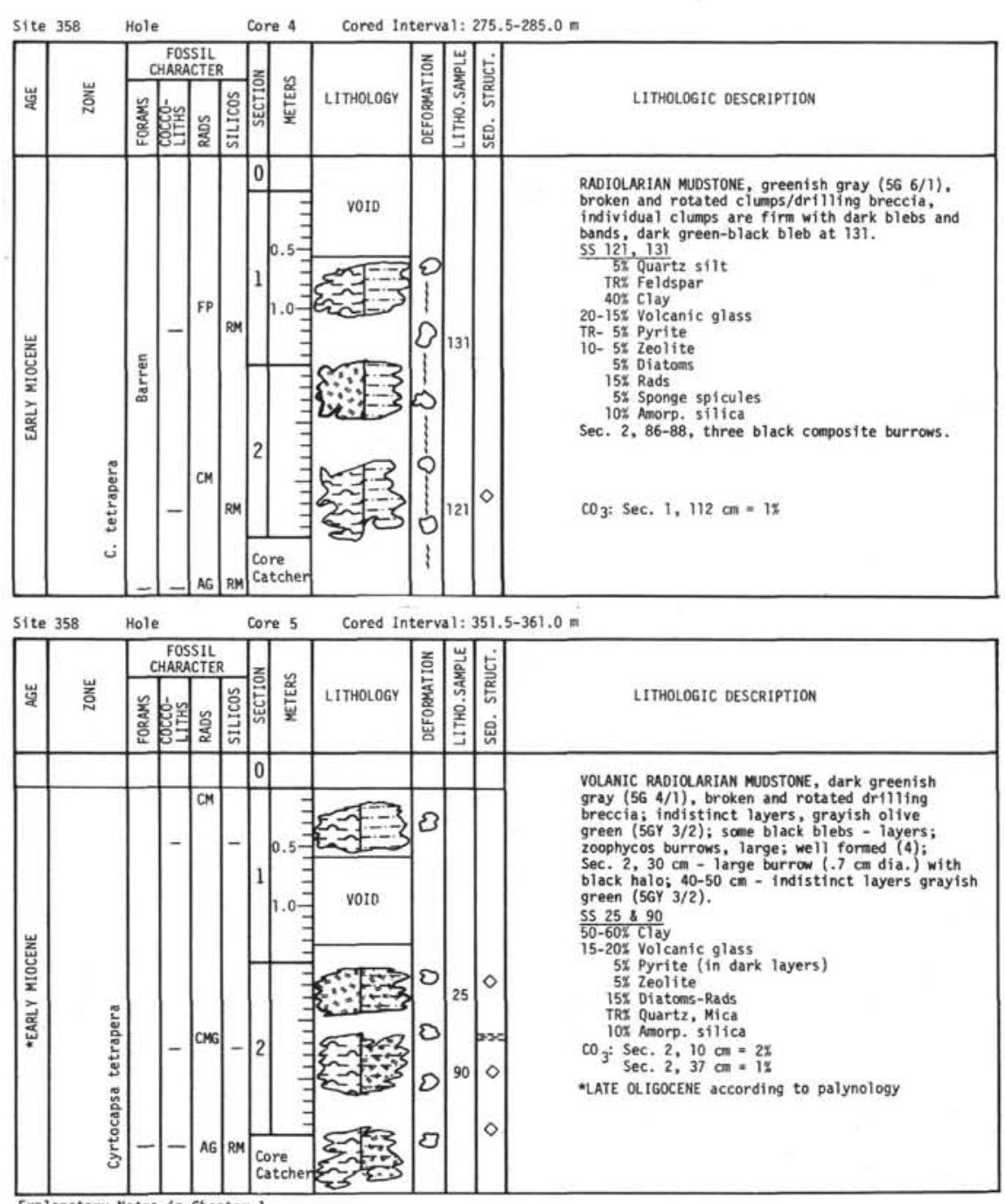



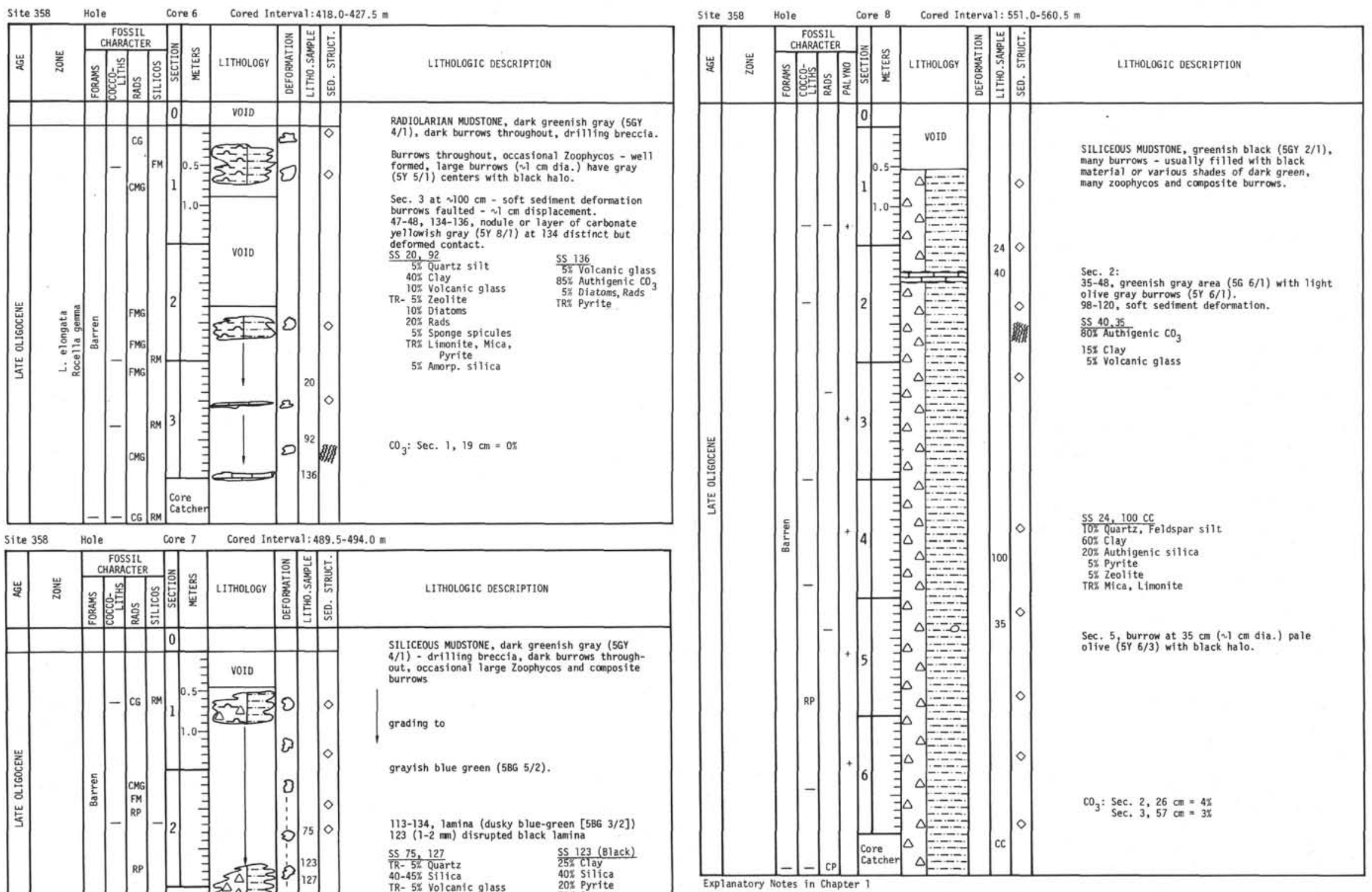

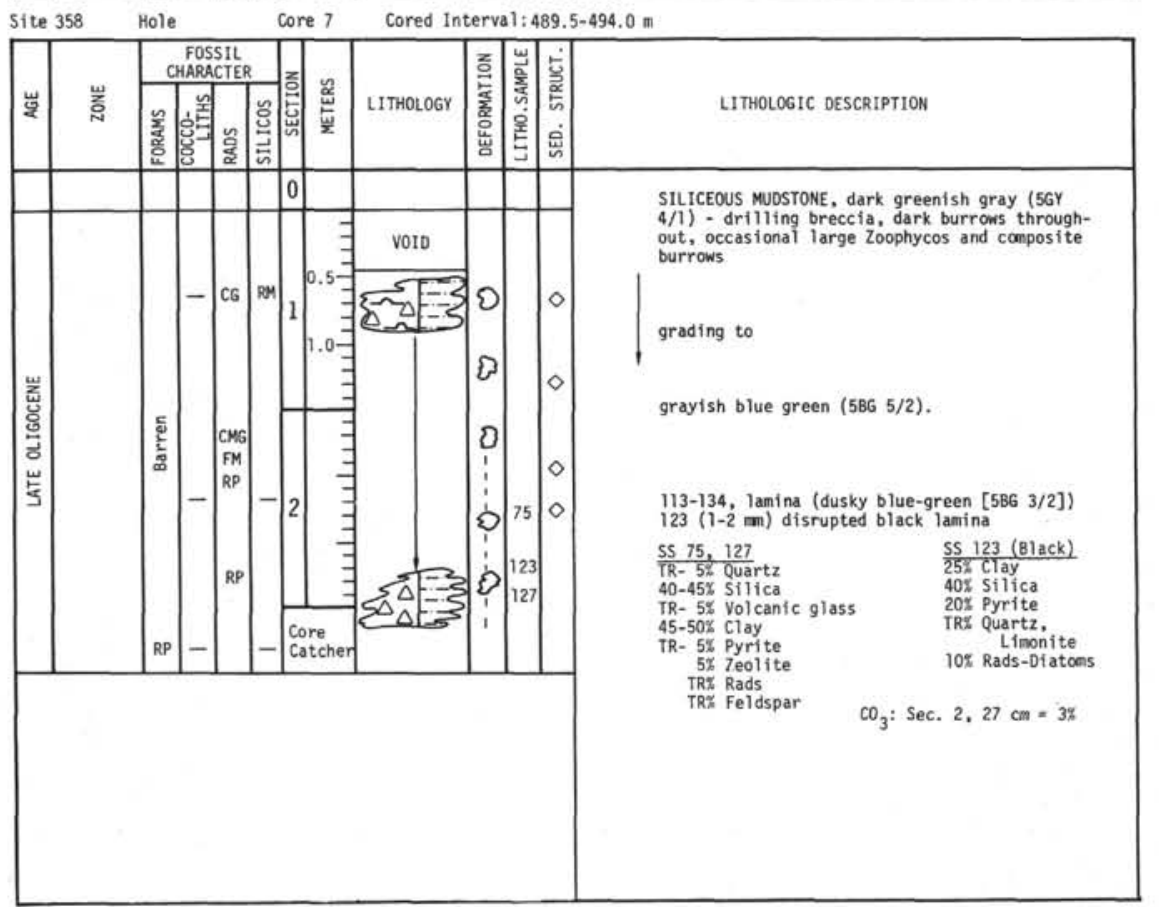




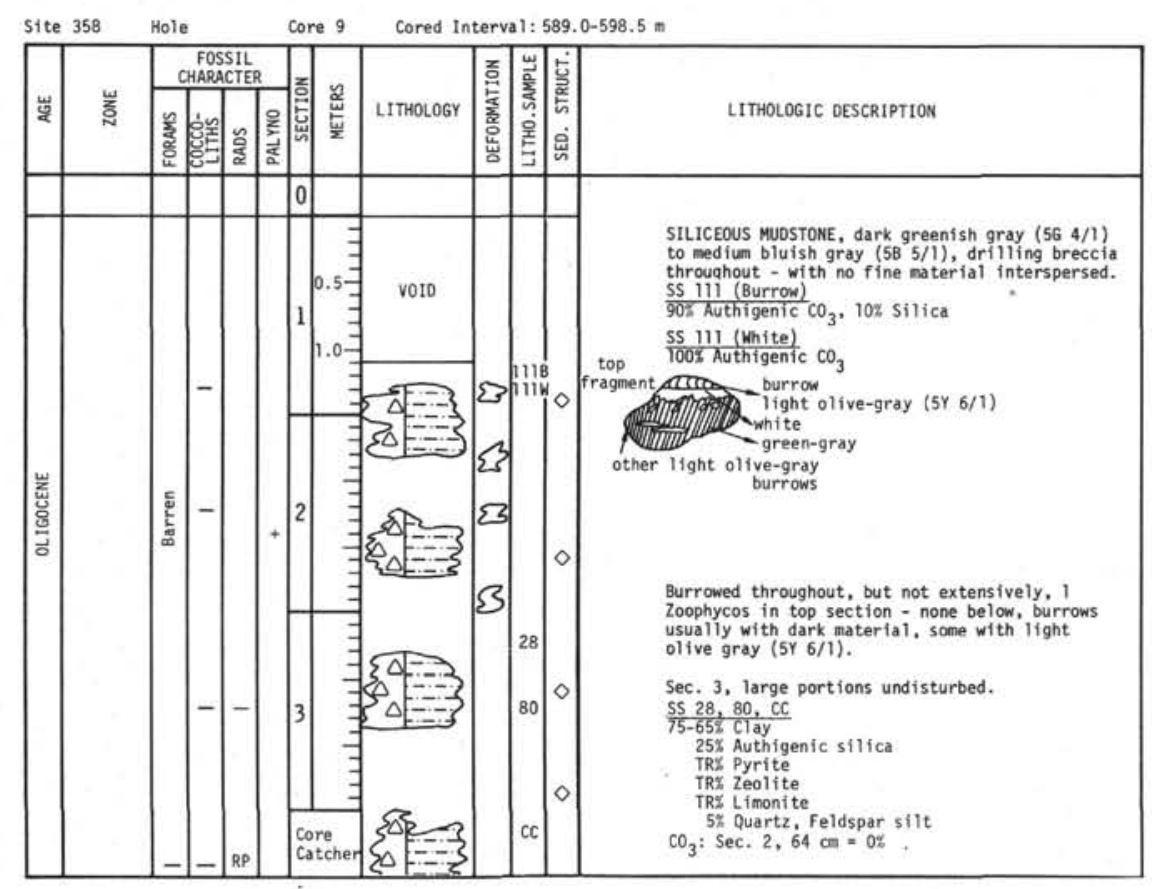

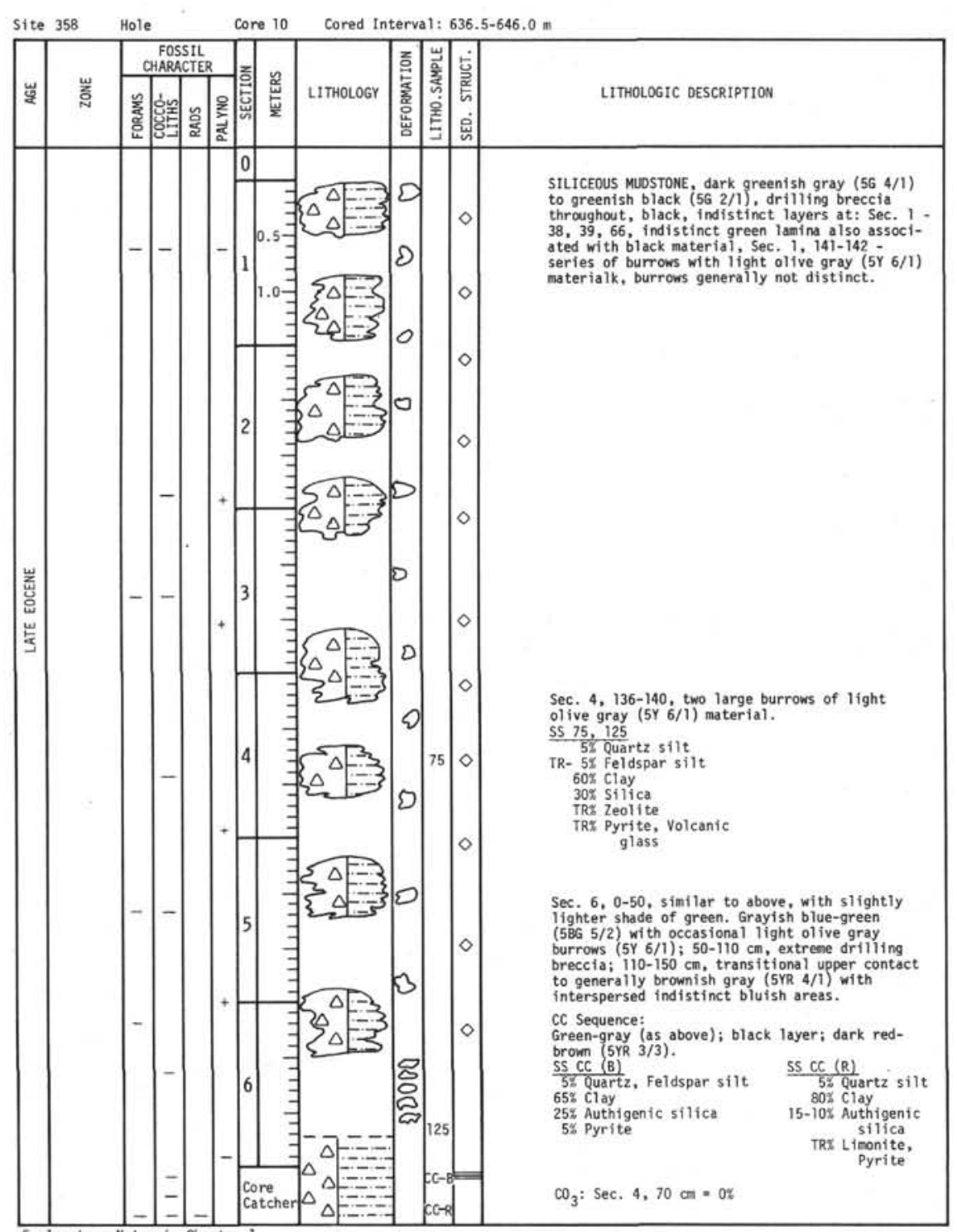

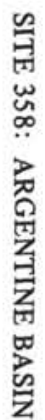




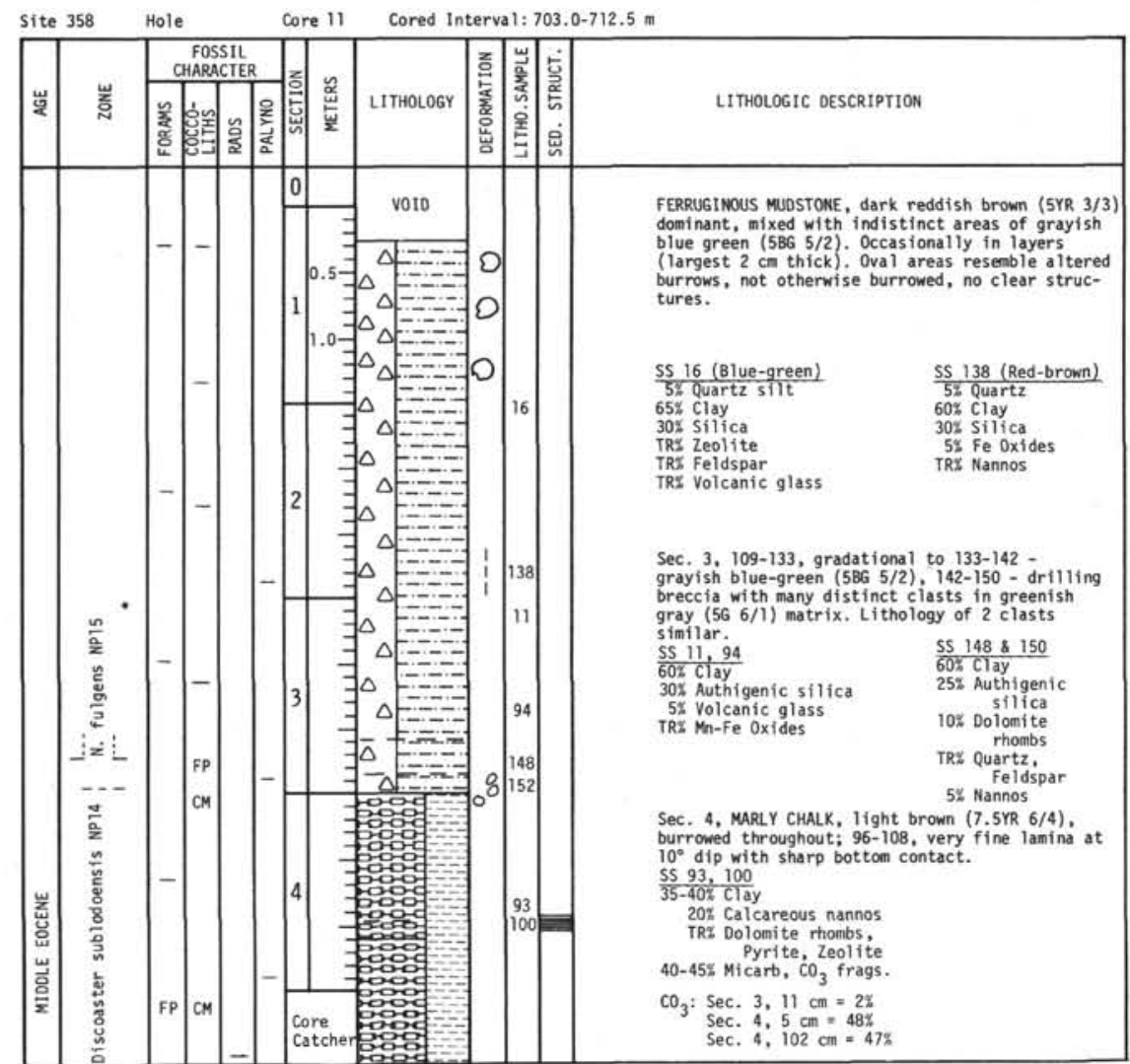

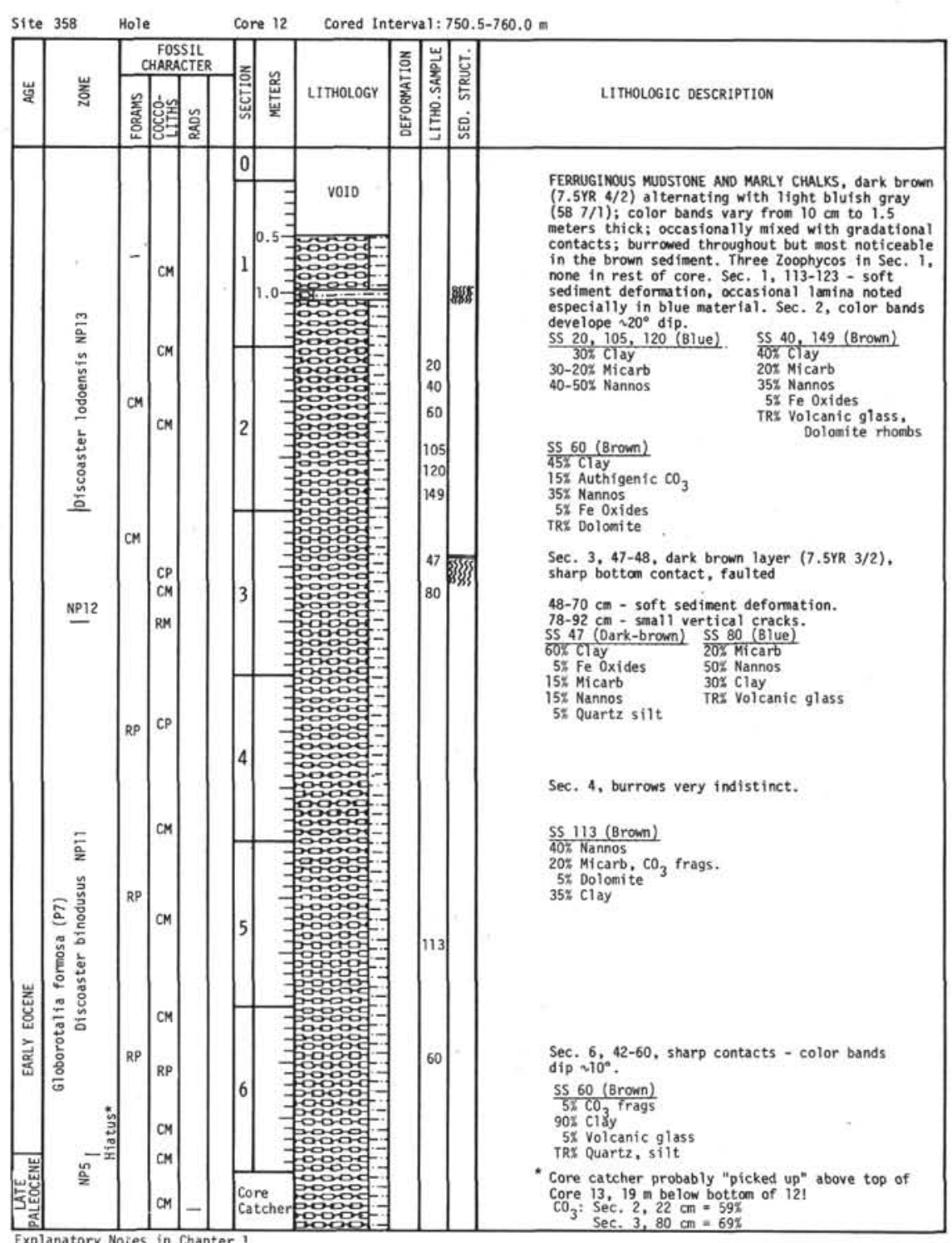



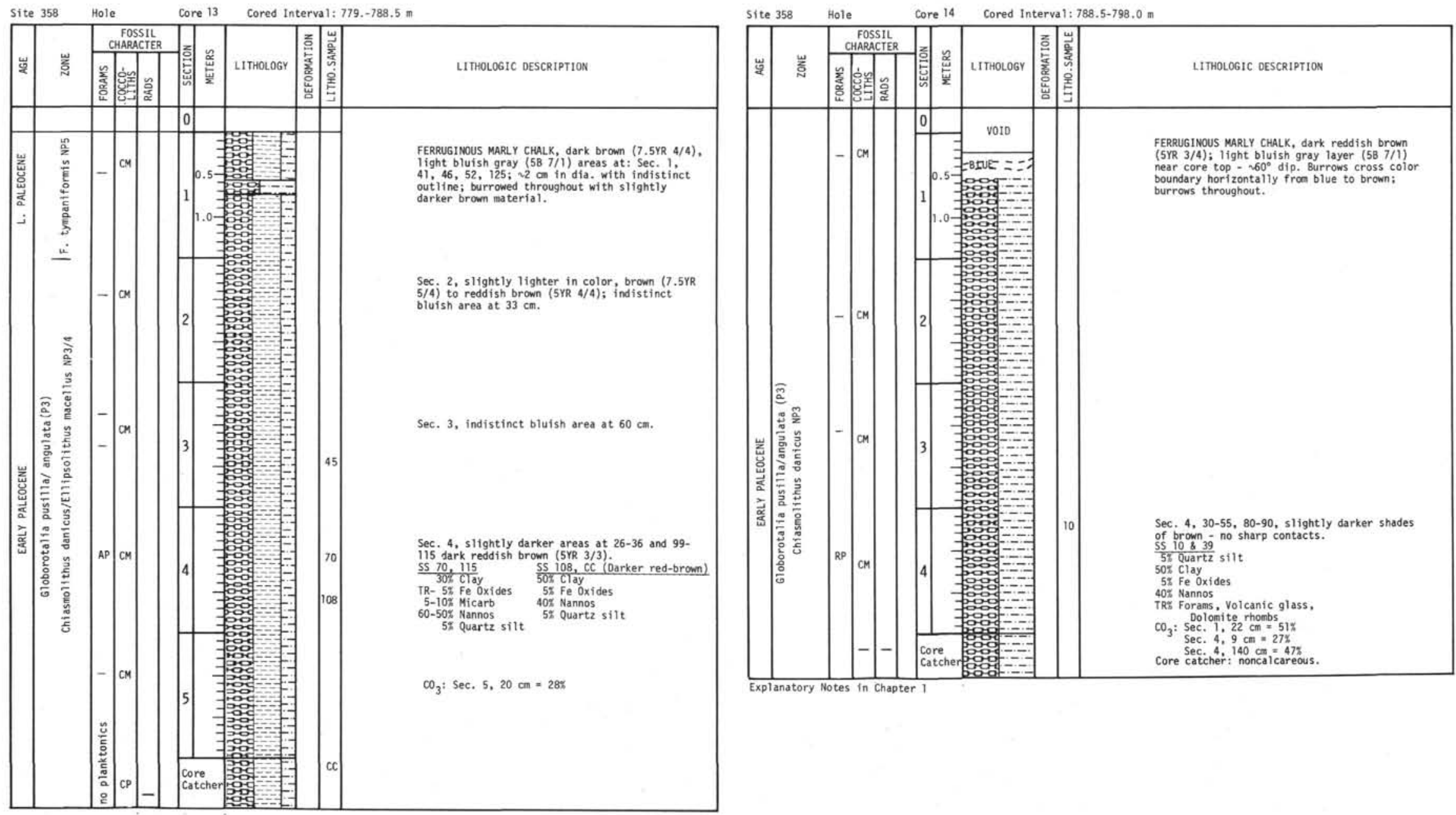


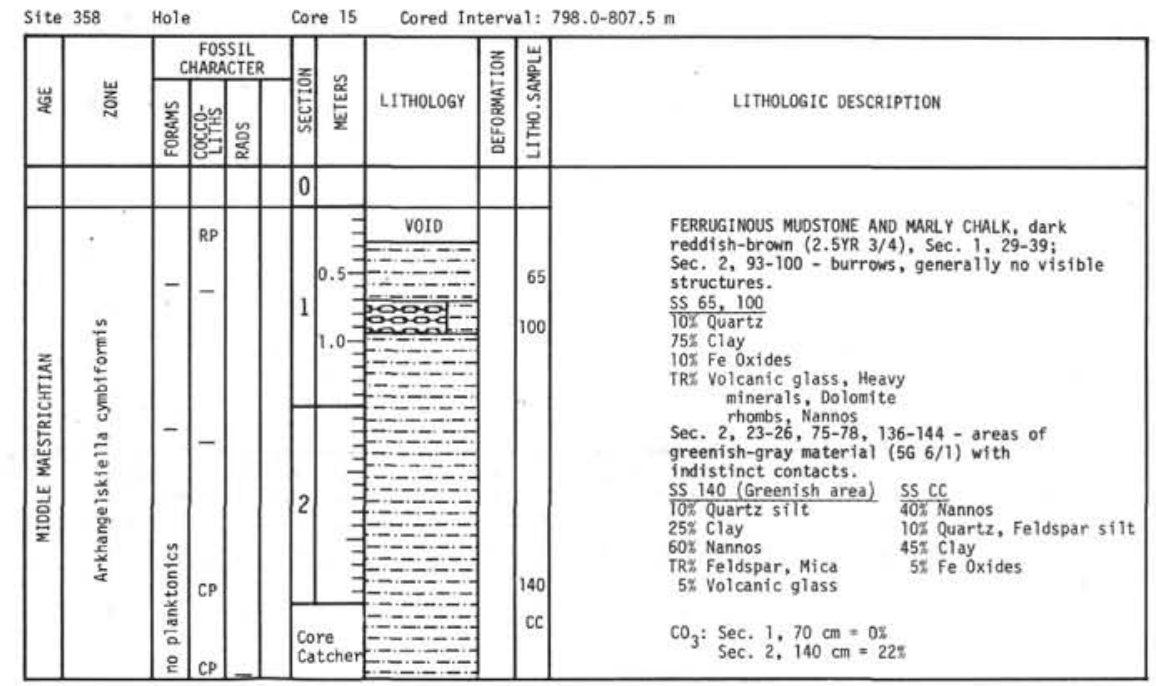

\begin{tabular}{|l|l|l|l|l|l|l|l|}
\hline \multirow{2}{*}{ Site 358} & Hole \\
\hline
\end{tabular}

Explanatory Notes in Chapter 1 


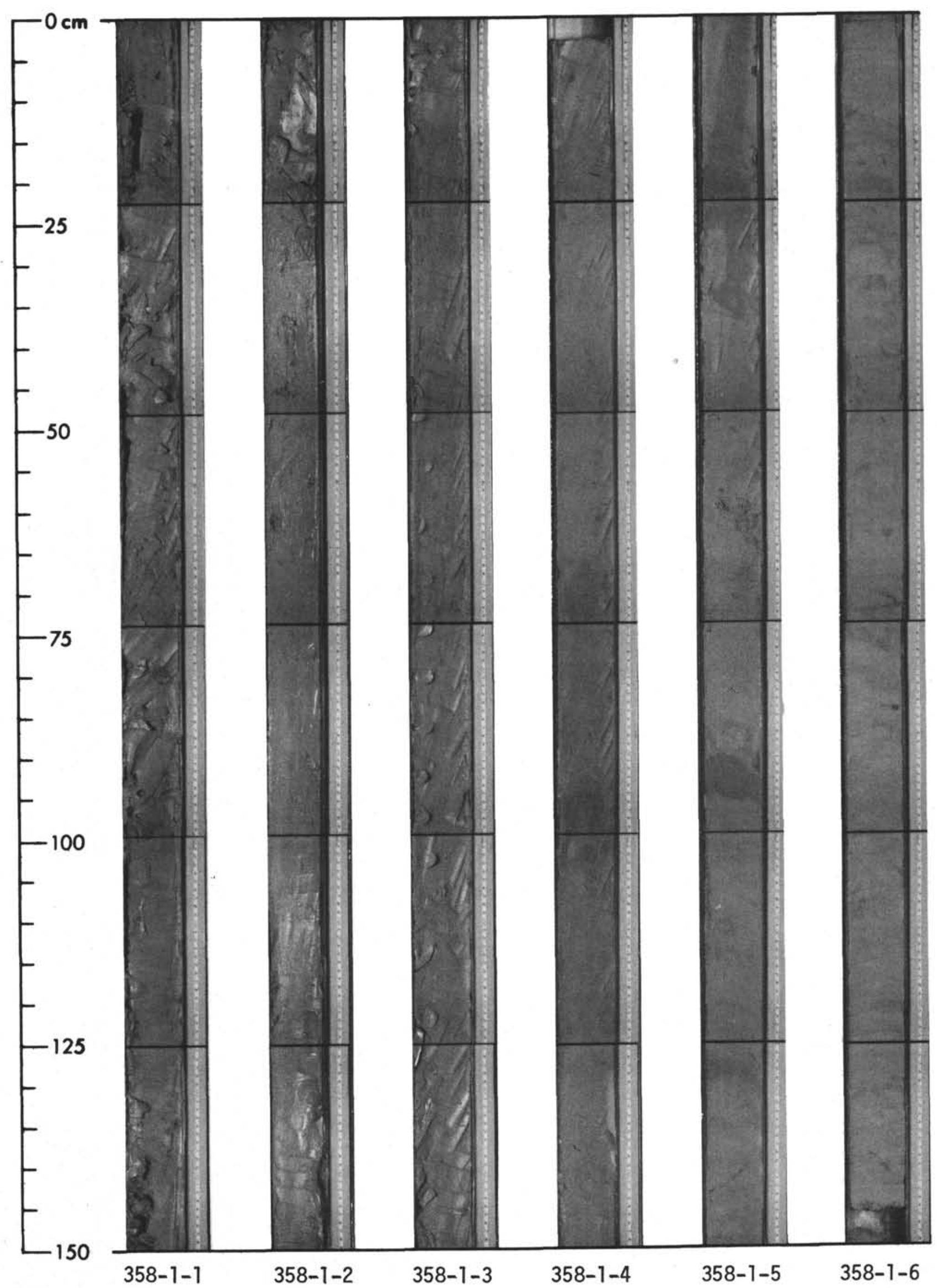









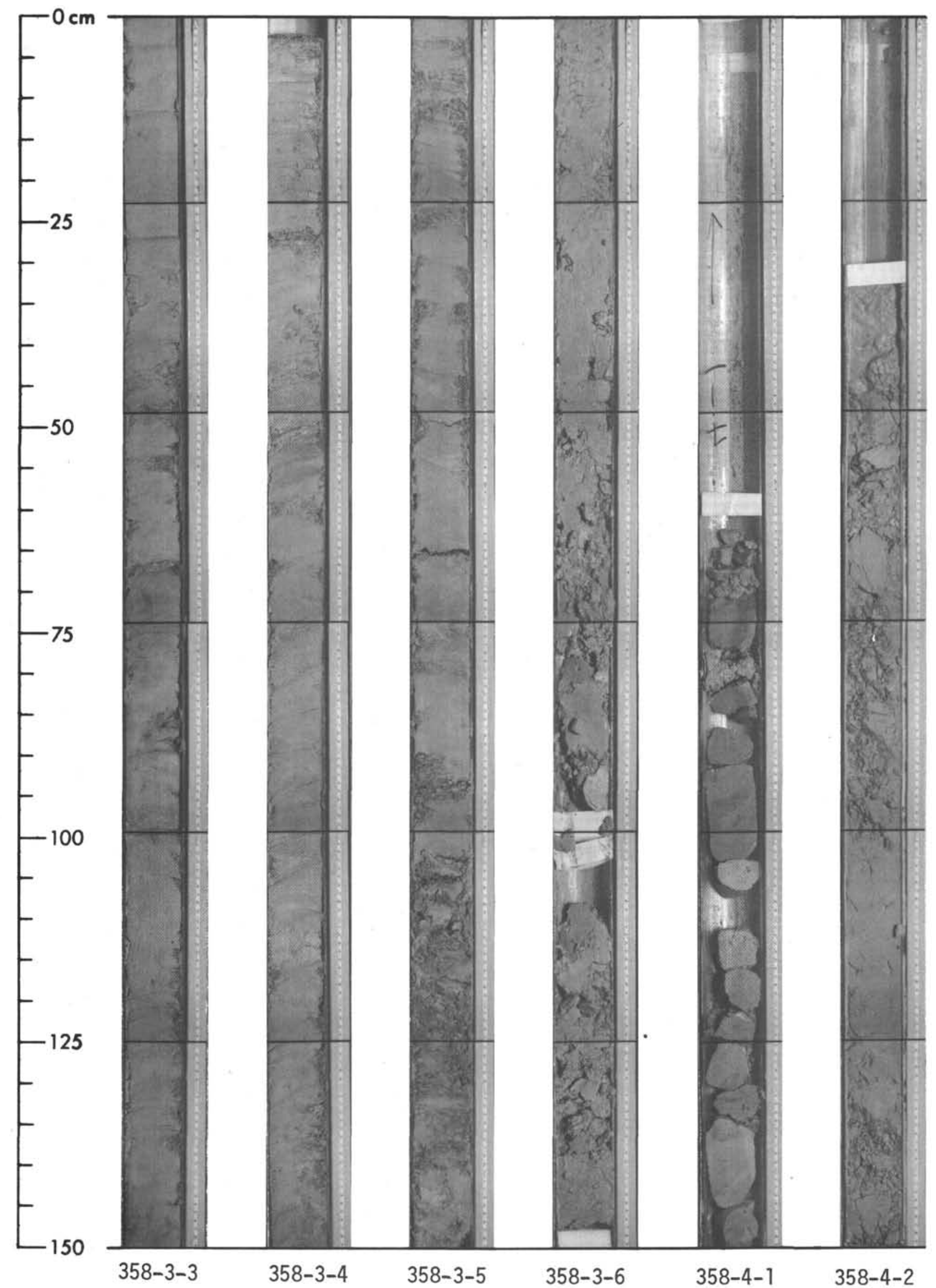




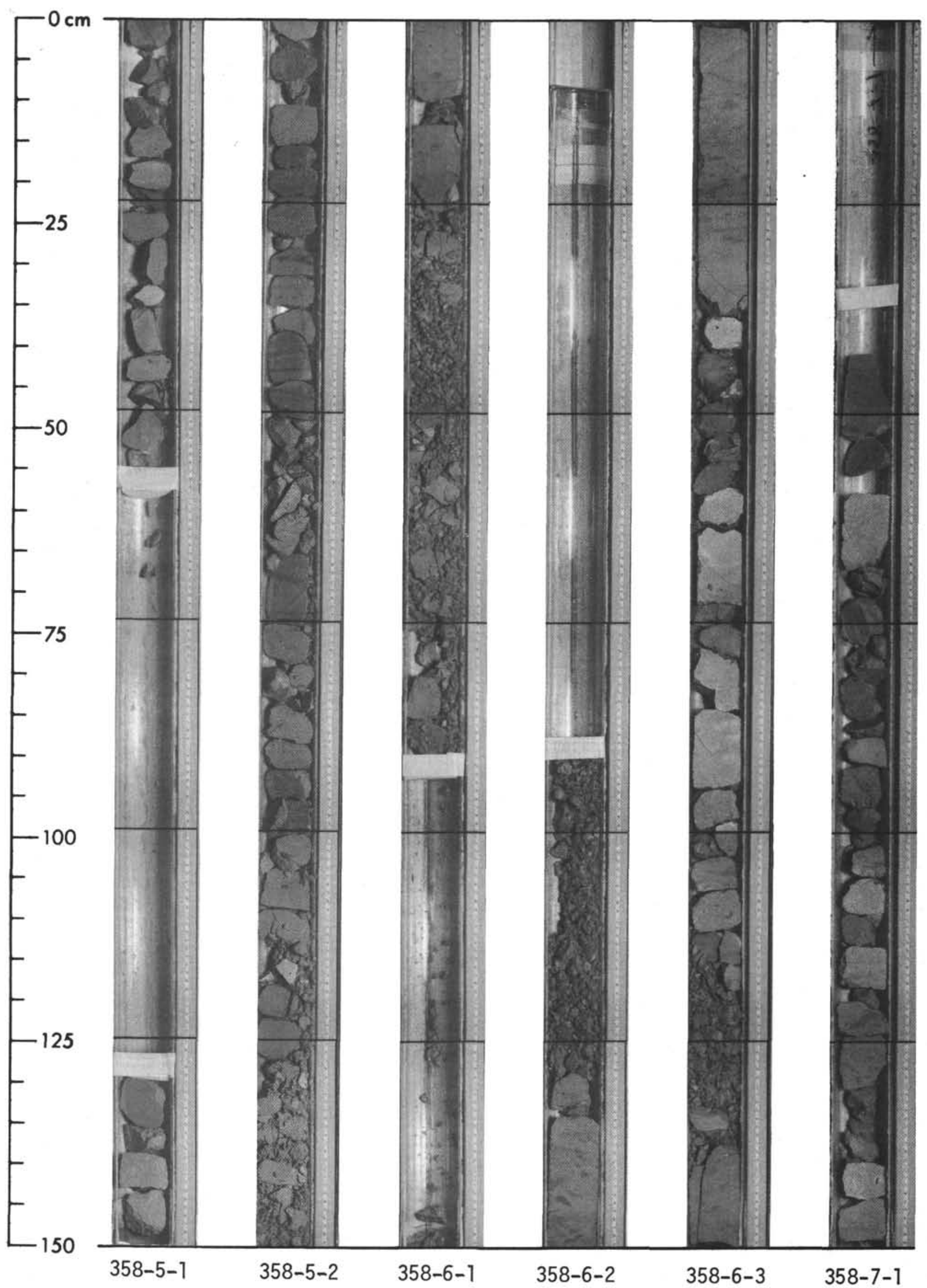




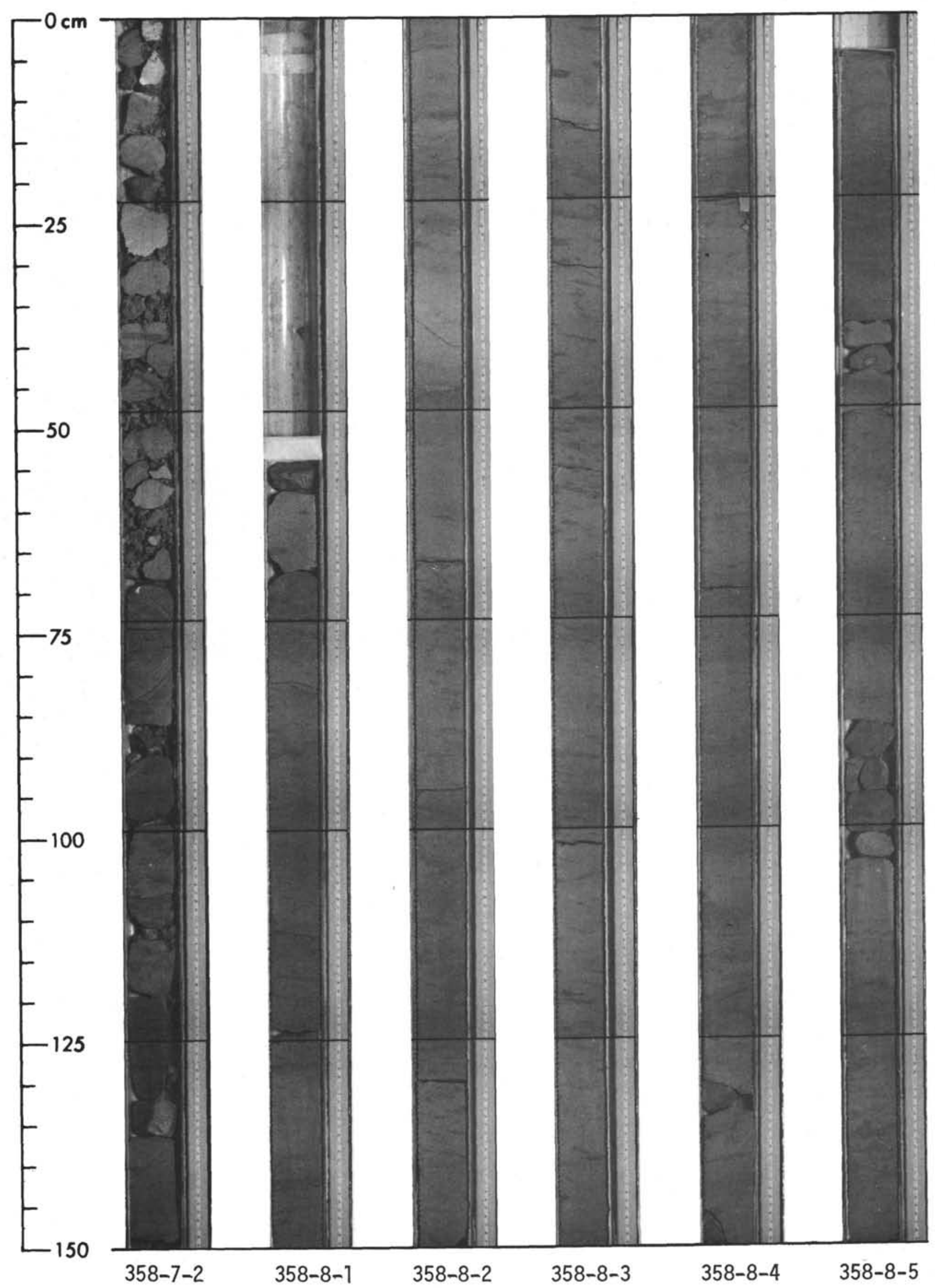




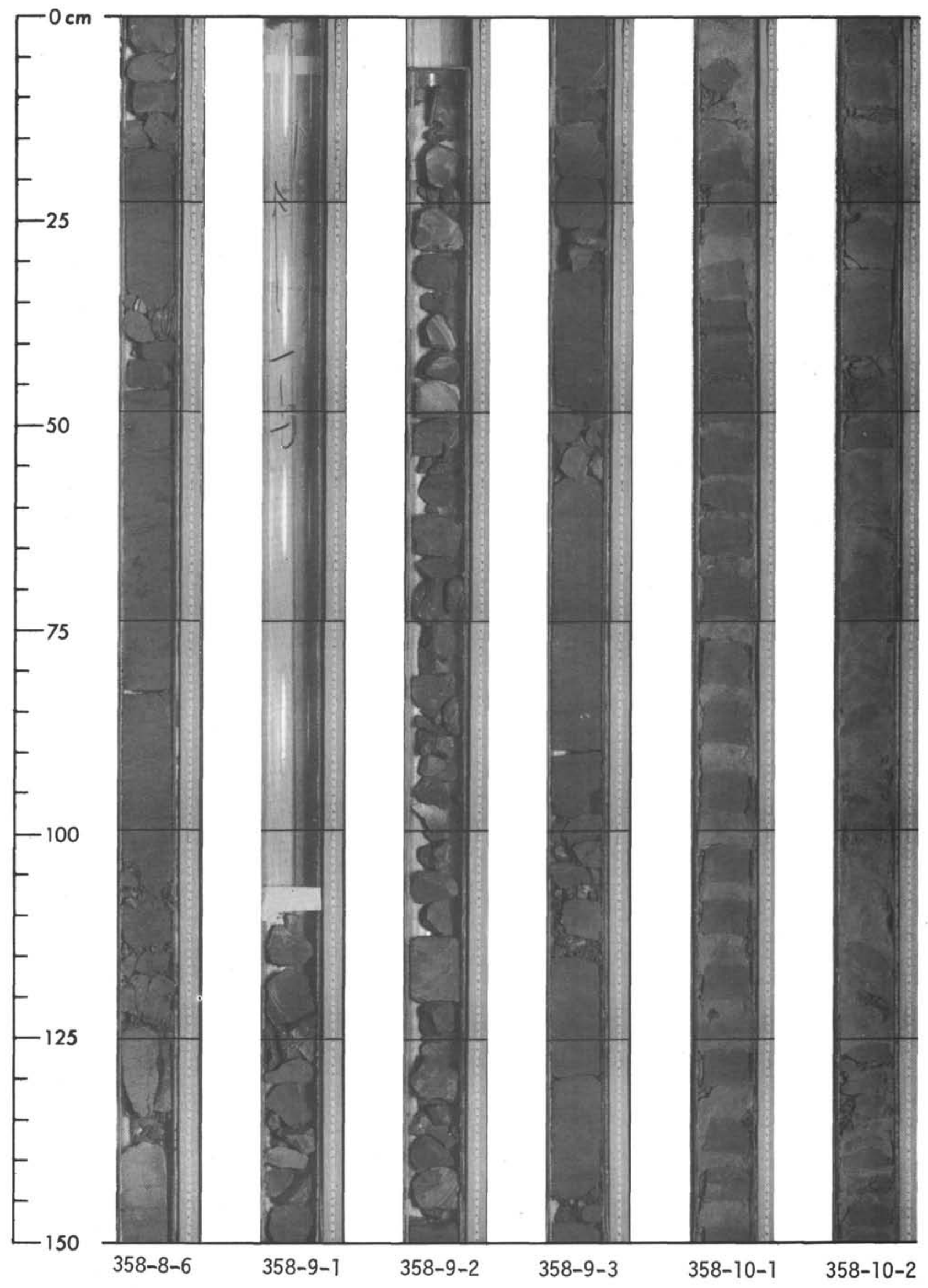




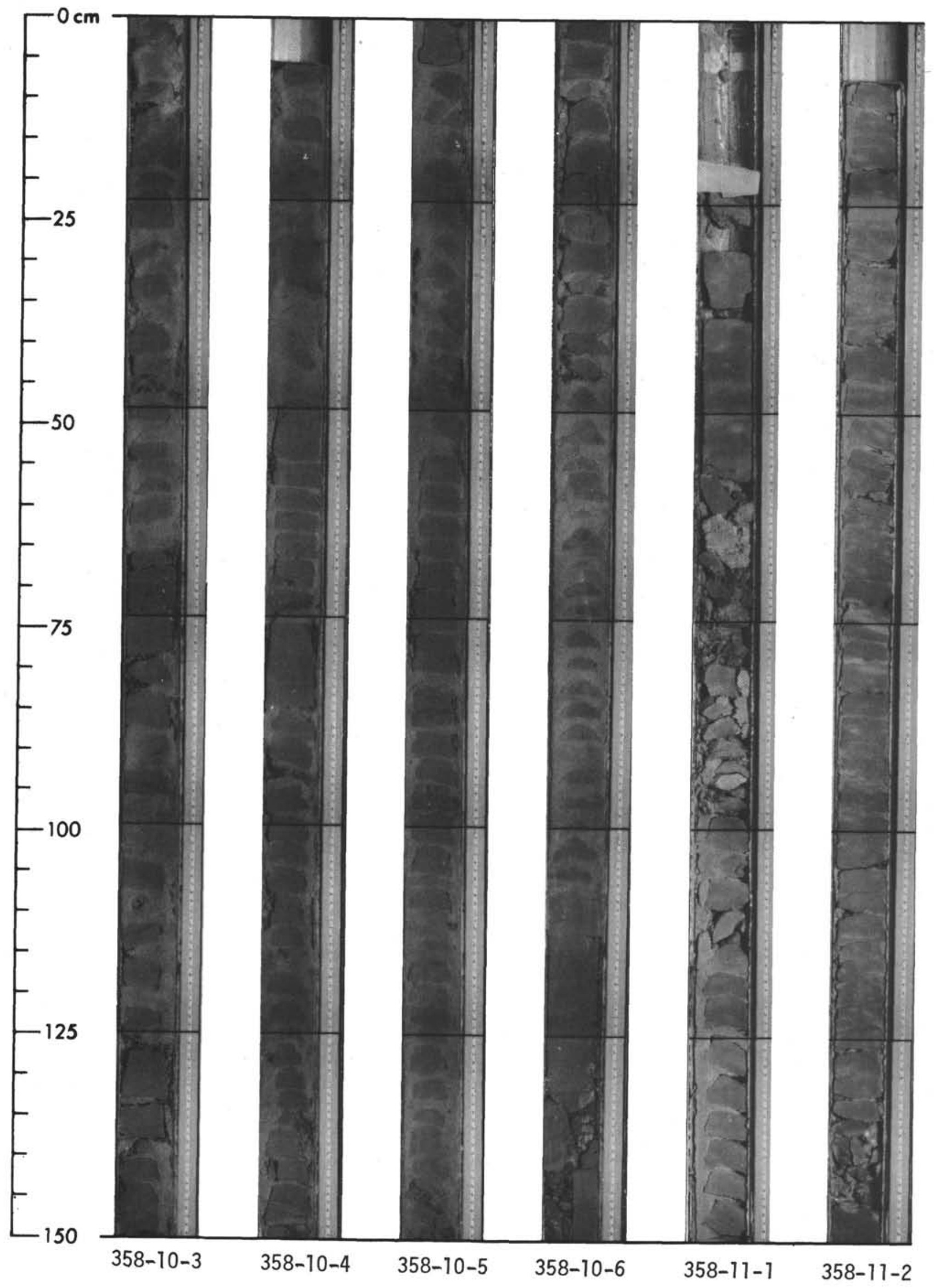




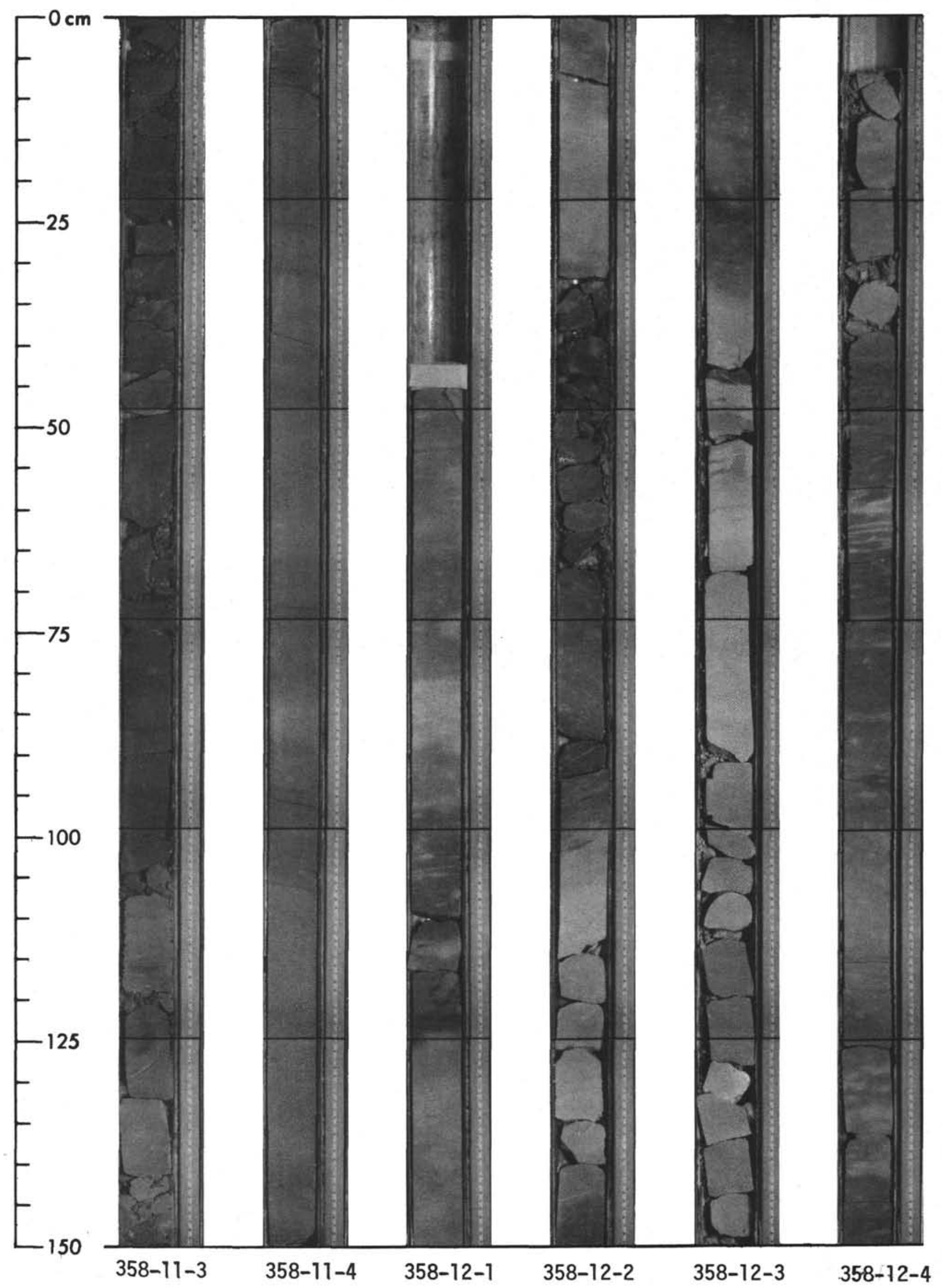




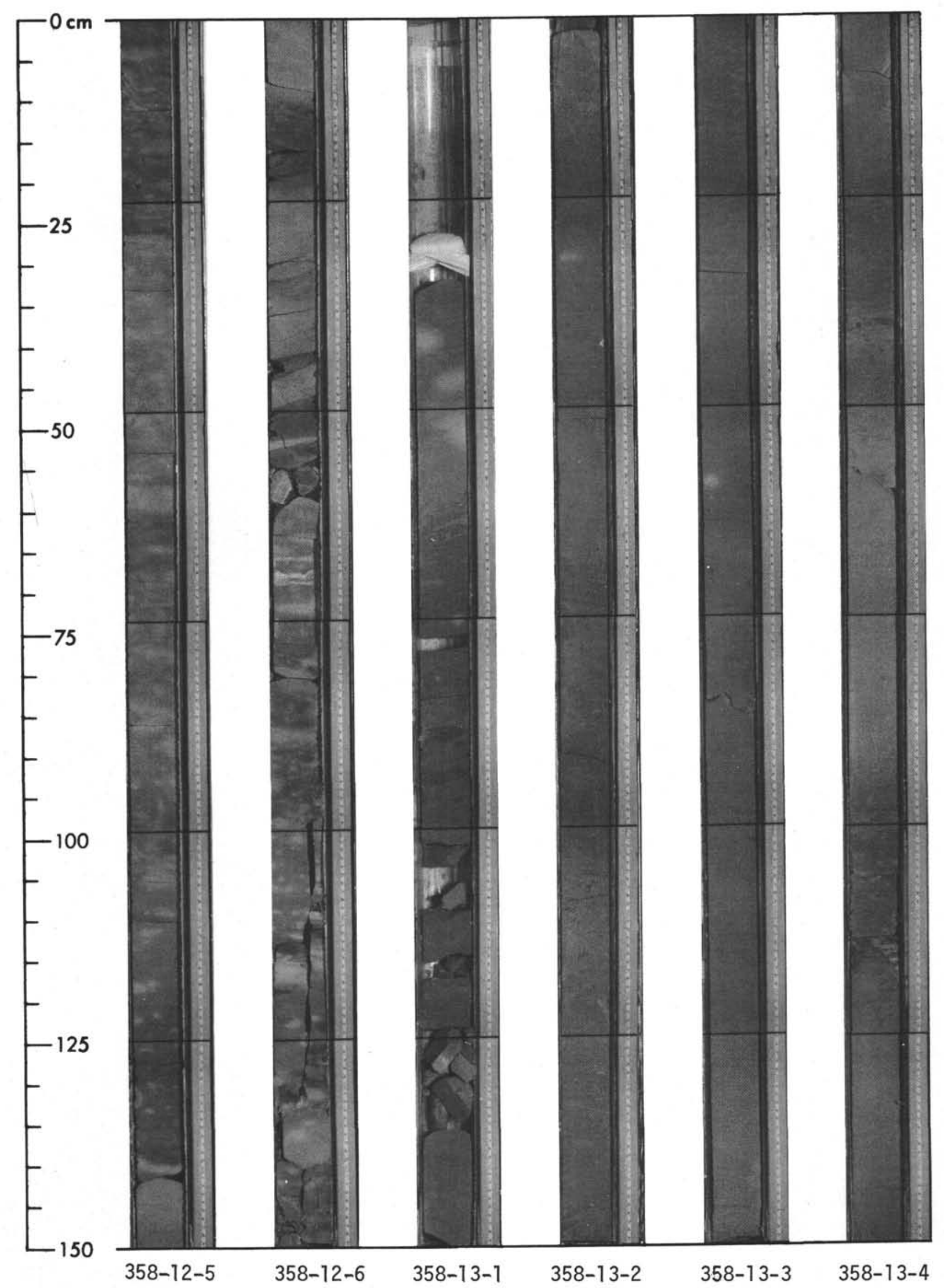




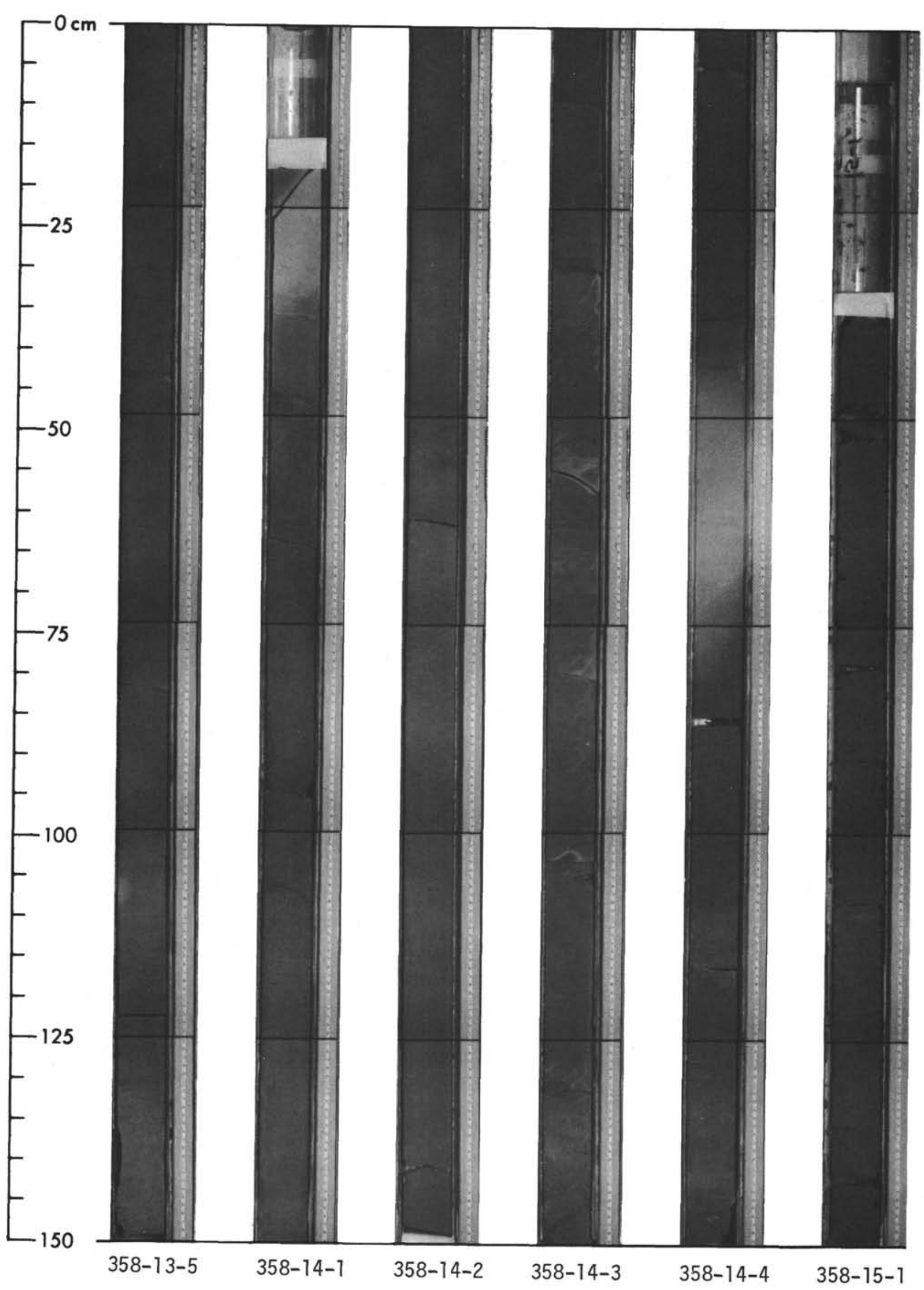


SITE 358: ARGENTINE BASIN

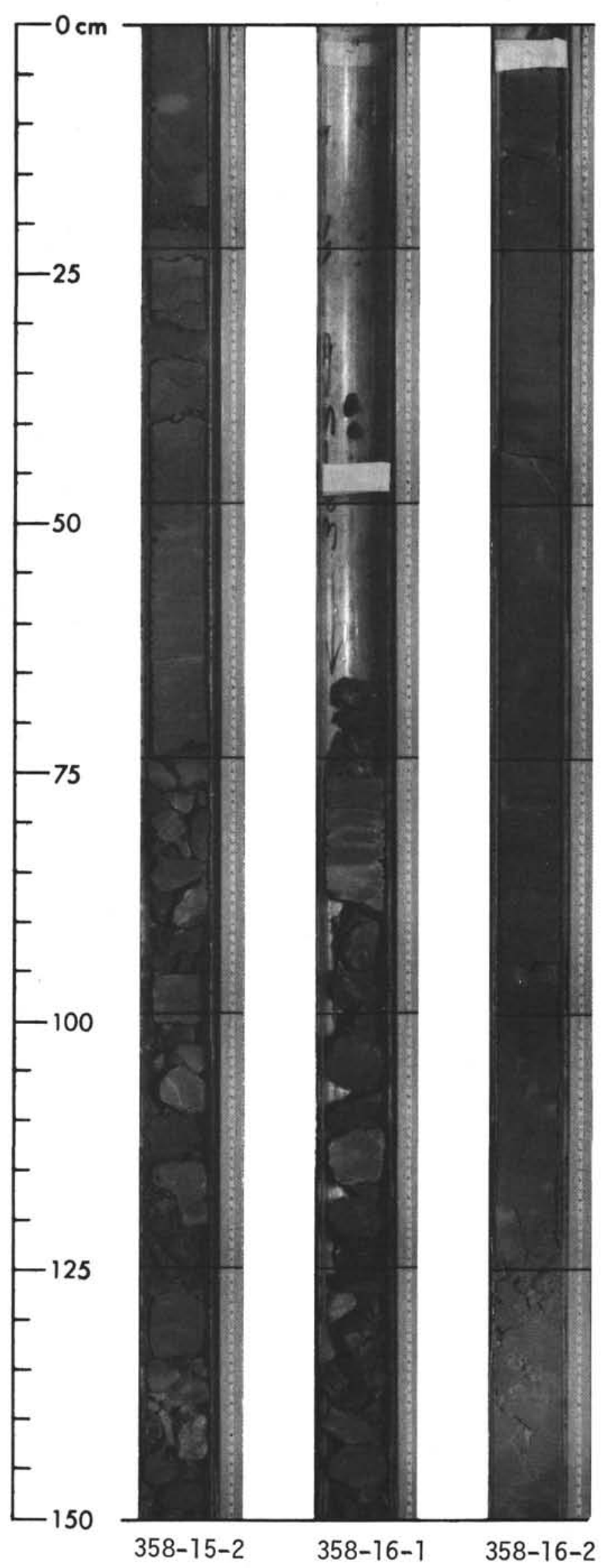

